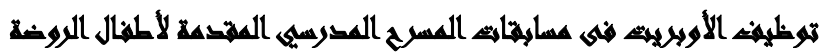

"عراسما تشليلية"

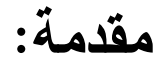

الطفولـة هى أغلى وديعـة من ودائع الله للإنسـان، أمانـة الأجيال وصـانعة

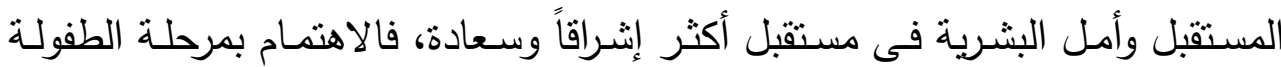

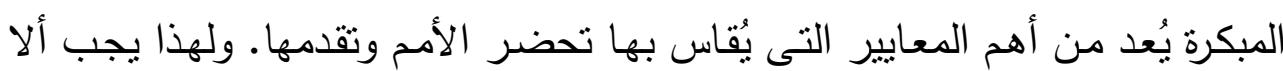

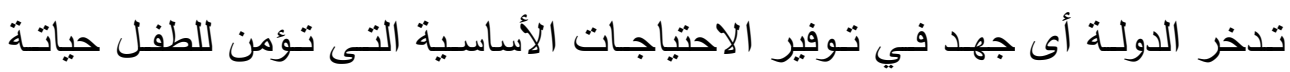

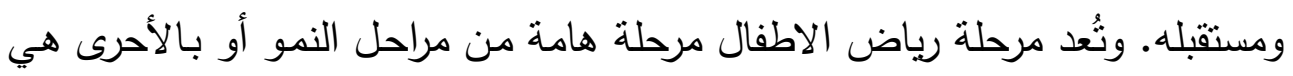

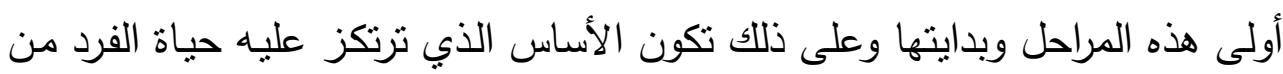

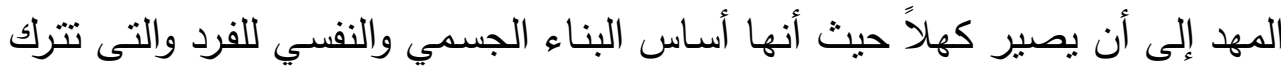
علامات واضحة على سلوكة وشخصيته وتؤثر في مستقبله فيتعرف الطفل على ذاته وعلى العالم المحيط به من خلال نشاطه في جميع المجالات.ومرحلة الطفولة المبكرة

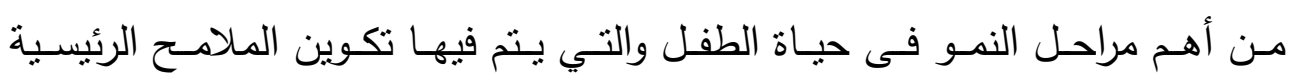

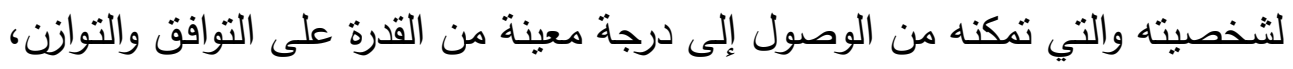
وهو بذلك يتجه إلى التكوين المتكامل للثخصية السوية السليمة في المستقبل.

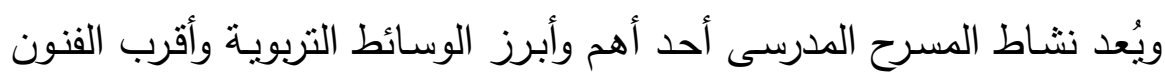

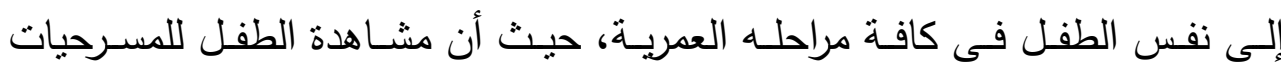
بمختلف أنواعها ومشاركته فى تمثيلها تتيح له الفرصة للتعبير عن انفعالاته ورغباته

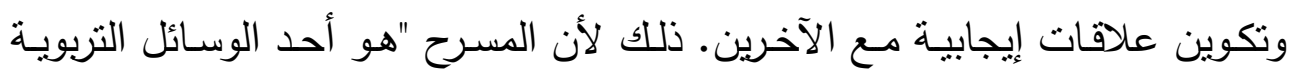

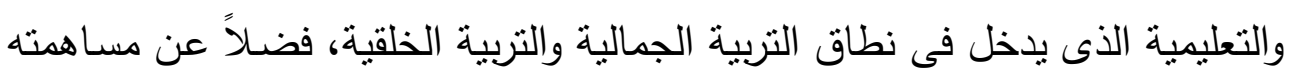

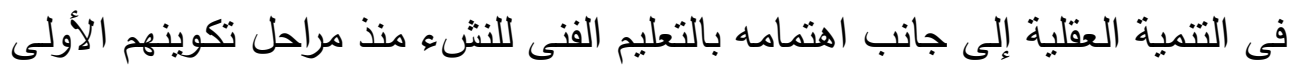

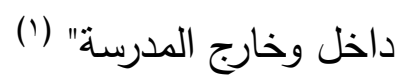




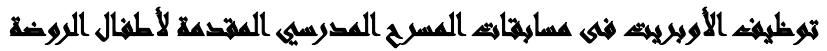

\section{"عراسها تطليلية"}

وفى ضوء اهتمام الدولة بالأنشطة الفنية وخاصةً النشاط المسرحى بالمدارس،

وجدت الباحثة من خلا الإطلاع على نتائج الدراسات السابقة ومن خلال احتكاكها بـالطلاب وحضـور مسـابقات النشـاط المسـرحى بـالإدارات التعليميـة التابعـة لمحافظـة القليوبيـة لاحظت الباحثنة أن تلاميذ ريـاض الأطفال لديهم العديد من المواهب فى مجال التمثيل والغناء والفنون المسرحية .وقد أكدت على ذلك العديد من الدراسـات السـابقة التى تتاولت المسرح المدرسى وربطه بأطفال الروضـة، وذلك بهدف تكوين إطار مفاهيمى تستتد إليه الدراسة الحالية فى توضيح الجوانب الأساسية لموضوعها، وكذلك الوقوف على أوجه القوة فى الظاهرة موضوع البحث وذلك بهذف : التعـرف على بعض الجهود التى بُذلت فيى مجـال الدراسـة ، والاستفادة مـن منهجها فى البحث وأهم النتائج التى توصلت إليها . تحديد أوجه التشابه والاختلاف بين الدراسات السابقة والدراسـة الحالية، ومن ثم يتضح مدى إسهام الدراسة الحالية فى هذا المجال. الدراساث التى تناولث الأويريث:

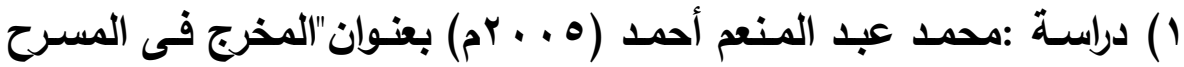

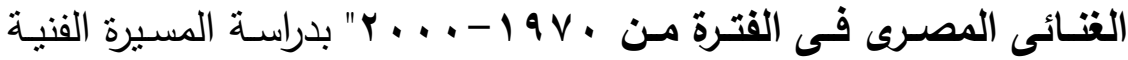
للمسرح الغنائى فى مصر منذ البدايات وحتى أواخر التسعينيات منوقفاً فى

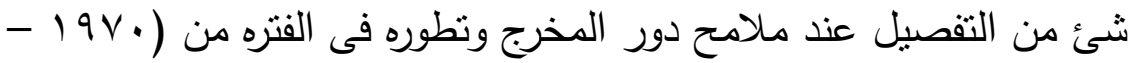
) F . . . توصل الباحث إلى عدة نتائج يجملها فيما يلى : يرتكز المسرح الغنائى فى بنائهه على مجموعـة من العناصـر الفنبـة الهامـة تستتـد عليها

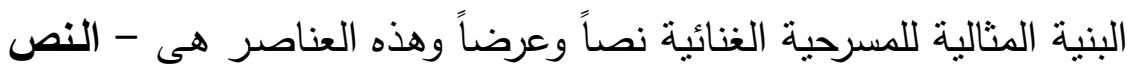
الأدبى - المؤلف الموسيقى - المغنى الممثل - الكورال - الأوركسترا.(؟) 


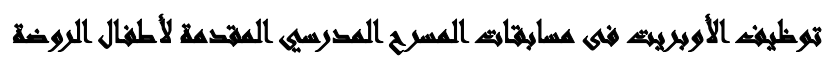

"عراسم تشليلية"

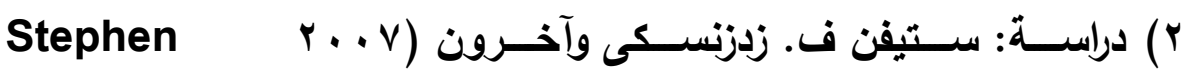

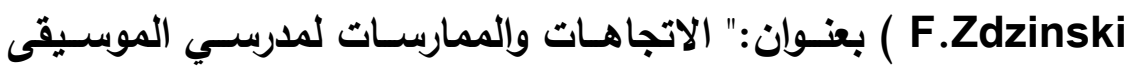
اليابانيـة والأمريكية نحو إدمـاج الموسيقى مـع المواد الدراسية الأخرى" وكان الغرض من هذه الدراسـة الدقارنـة بين الاتجاهات والممارسـات بين

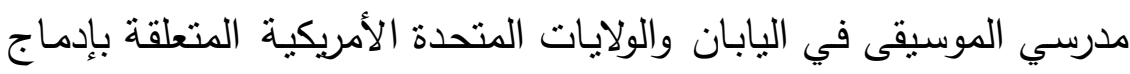
الموسيقى مـع المـواد الدراسية الأخرى. قام المعلمين باستكمال استبيان

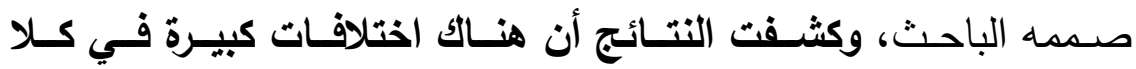

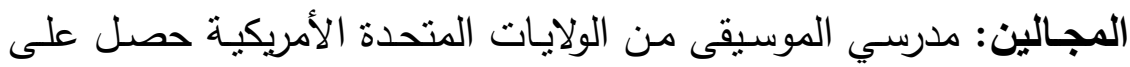

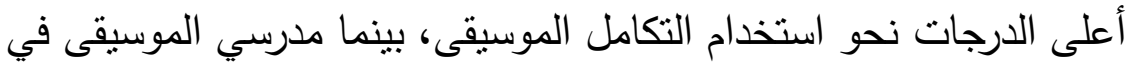

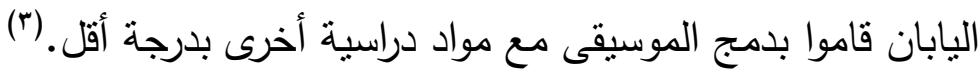

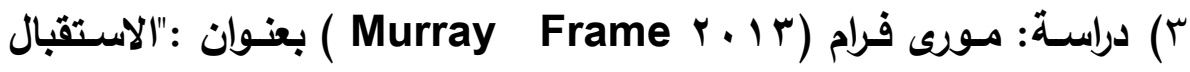

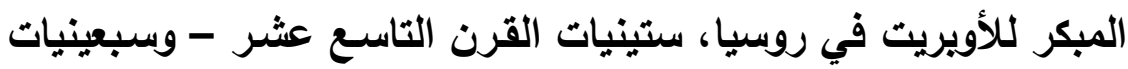
القرن التاسع عشر" ويستكثف هذا المقال القبول الثُبى والناقد للأوبريت

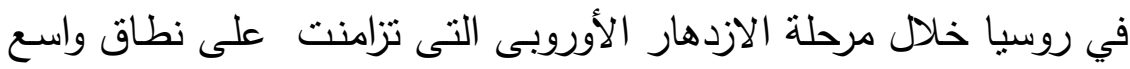

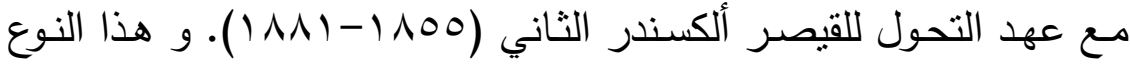

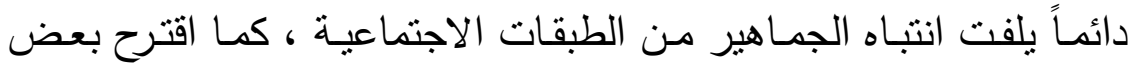
المؤرخين أنه نموذج فريد للبرجوازية للترفيه والتنلية ويرتبط ارتباطاً وثيقاً

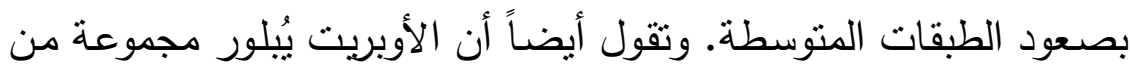

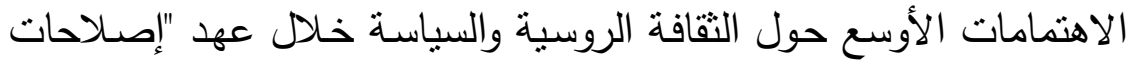

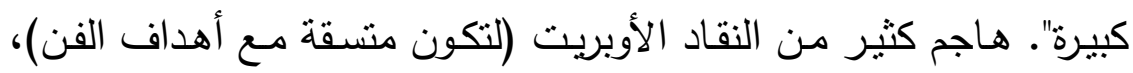

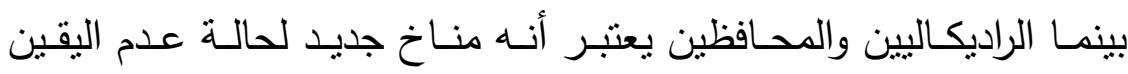




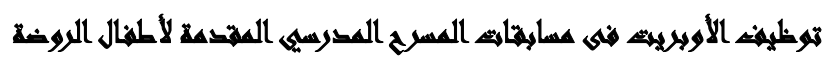

"عراسم تشليليه"

السياسي. وهكذا شهدت الردود الناقدة للأوبريت لشعبيتها وسرعة التغير في

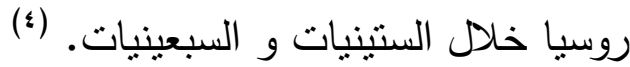

الاراسات التخى تثاولث فتون المسرح وعلاقته بأطةال

الروضة:

() دراسة : علا حسن كامـل سيد (V) . . rم) بعنوان : "فعالية برنـامج نشـاط تمثيلى مسرحى فى تنمية مفهوم المواطنة لأطفال الروضة" تهدف الدراسـة الحالية إلى التحقق من مدى فعالية برنامج النشاط التمثيلي المسرحي فى تتميـة مفهـوم المواطنـة لأطفـال الروضــة. و اسـتخدمت الدراسـة المـنهج التجريبي لمناسبته لطبيعـة هذه الدراسـة، وتمثلت عينة الدراسـة من (، (^) طفلاً وطفلة والملتحقين بالمستوى الثانى برياض الأطفال ـ وكان من أهم نتـائج الاراســة: وجـود فـروق دالـة احصـائياً بـين المجموعـات التجريبيـة التثلاث، و المجموعة الضـابطة لصـالح المجموعات التجربيية الثلاث ممـا يؤكد علـي فعاليـة برنـامج النشـاط التمنيلـي المسـرحي في تتميـة مفهوم

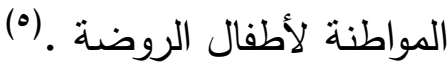

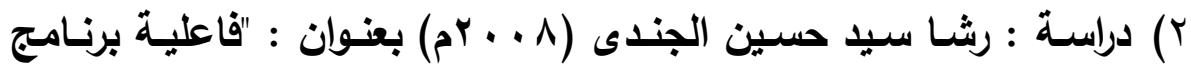
لتنميـة بعض المهـارات الحياتيـة لـدى طفـل الروضــة باسـتخدام مسـرح العرائس" وتهدف الدراسة الحالية إلى التحقق من مدى فاعلية برنامج مسرح العرائس المقترح في تتمية مهارات حل المشكلات واتخاذ القرار والاتصال لأطفـال الروضـة (ع-7) سـوات. وتعتمـد الدراسـة الحاليـة على اسـتخدام المـنهج التجريبـي، وتمثلـت أدوات الدراسـة فى عـدة أدوات منهـا اسـتمارة 


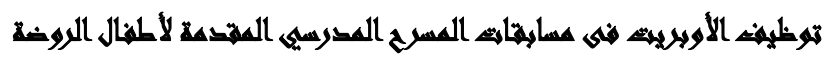

"عراسم تشليليه"

المسـتوى الاجتمـاعي/ الاقتصـادي/الثقـافي المطـور للأسـرة المصـرية. ومقيـاس المهارات الحياتيـة باستخدام مسـرح العرائس.وقــ أسـفرت نتـائج الدراسـة عن تأكيد الدور الفعال لبرنامج مسرح العرائس في تتمية مهارات حل المشكلات واتخـاذ القرار والاتصـال لدى طفل الروضــة، وقد أثبتت الدراسة الحالية صحة الفرض الأول والثاني والثالث والرابع. (؟)

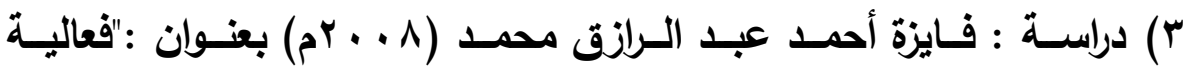
استخدام مسرح العرائس فى تتميـة بعض الجوانب الاجتماعية والأخلاقية للتربية البيئية لاى طقل الروضة" تتحدد أهداف البحث فى تحديد الجوانب الاجتماعيـة والأخلاقيـة للتربيـة البيائيـة الواجب نتميتهـا للدى طفل الروضــة وقياس فعالية استخدام مسرح العرائس في تتمية بعض الجوانب الاجتماعية والأخلاقيـة للتربيـة البيئية لدى طفل الروضـة. اتبع البحث الحالي المنهج التجريبـي، ومن أهم أدوات البحث قائمسة الجوانب الاجتماعيـة والأخلاقيـة للتربية البيئية لدى طفل الروضـة. ومن أهم نتائج البحث وجود فروق ذات دلالــة إحصـائية بـين متوسـطي درجـات كـل مـن المجموعـة التجريبيـة، والمجموعـة الضـابطة فـي التطبيـق البعـدي للمقيـاس المصـور للجوانـب

الاجتماعية، والأخلاقية للتربية البيئية لصالح المجموعة التجريبية. (v)

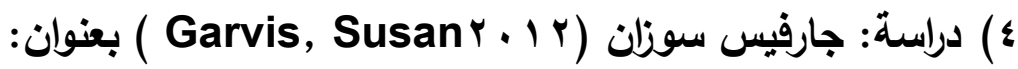
"استكثاف ممارسة الفنون الحالية في رياض الأطفال وصفوف مرحلة التعليم الأساسسى" هذه الورقة البحثية تقدم تقريراً عن الممارسـة الحالية للفنون في فصلين لرياض الأطفال واثثين من الفصـول الدراسية فى مرحلـة التعليم

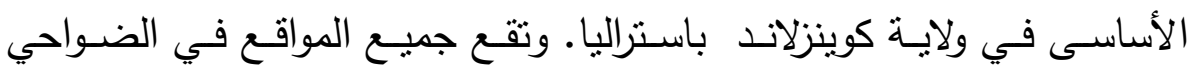




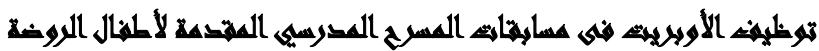

\section{"عراسها تطليلية"}

المجاورة. وتكثف النتائج التي توصل إلبها الباحث إلى أن الأطفال في رياض الأطفال يتعرضون لبيئة غنيـة بالفنون. وفي الفصول الدراسية لمرحلة التعليم الأساسى، يمكن ملاحظة أمثلة قليلة من أنشطة الفنون، مع الأطفال سوى درس الموسـيقى ، ب دقيقـة أسـبوعياً مـع مـدرس متخصـص. وممارسـة الفنـون في كي الفصول تتصل بفلسفة كل معلم لتعليم الفنون وتوصى بضرورة تسليط الضوء على أهمية تعليم الفنون الكافية في برامج تعليم المعلمين في مرحلة الطفولة

(^) المبكرة.

0) دراسة : ريهام رييع مصطفى العيوطى (T I • rم) بعنوان: "تنمية بعض المفـاهيم الاقتصـادية باسـتخدام الأنثـطة المسـرحية وعلاقتهـا بمظـاهر السلوك التوافقى لطفل الروضـة (ع - צ) سنوات " هدفت هذه الدراسة إلي قباس فعاليـة الأنشطة المسرحية المصممة بالدراسـة الحاليـة لتتميـة بعض المفاهيم الاقتصادية المحددة المناسبة لطفل الروضة (ع-7) سنوات. ومن أهم أدوات الدراسـة مقياس المفاهيم الاقتصادية الإكتروني المصور لطفل الروضــة (ع - 7) سـنوات، وبرنـامج الأنشـطة المسـرحية لتنميـة بعـض

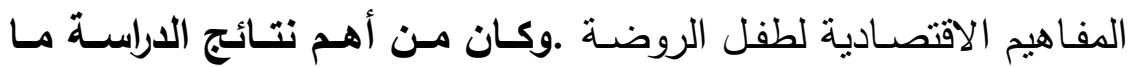
يليـي:- وجـود علاقـة ارتباطيـة إيجابيـة ذات دلالـة إحصـائية بـين درجـات أطفال المجموعـة التجربييـة علي مقيـاس المفاهيم الاقتصـادية الاككتروني المصـور لطفل الروضــة (صـورة الطفل) ودرجاتها علي بطاقـة ملاحظـة السـوك التوافقي لطفل الروضــة (صسورة المعلمة) في القياس البعدي بعد تطبيق برنامج الأنشطة المسرحية المستخدم. (9) 


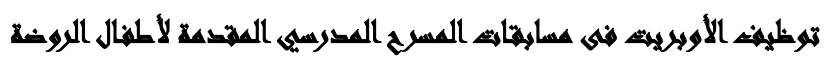

"عراسما تشليلية"

الاراسات التى تناولت المسرح المدرسى:

( ) دراسـة: أمل عـادل كامـل (9 . . rم) بعنـوان: "الأبعاد التريويـة والجماليـة

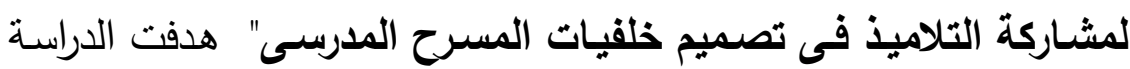
إلى تصميم خلفيات المسرح المدرسى بمشـاركة التلاميذ مـع معلم التربيـة الفنية وذلك باختيار بعض رسومهم لعمل الخلفية المسرحية والمعبر بها عن لهن

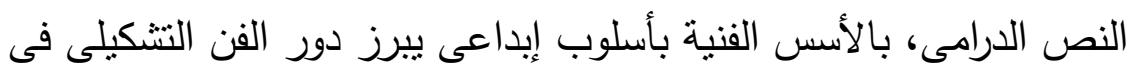

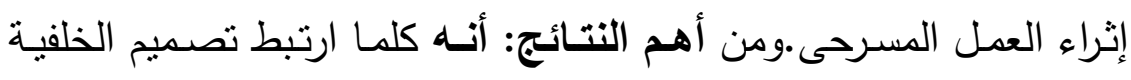
بالعالم الخاص بالأطفال و تم صباغة رموزه و عناصره منبنقة من عالم

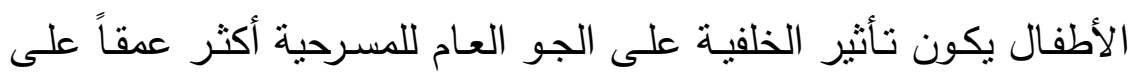

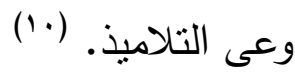

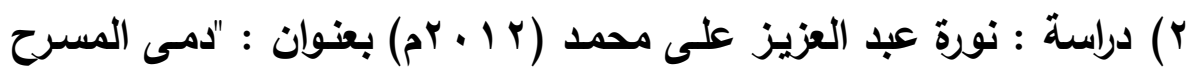

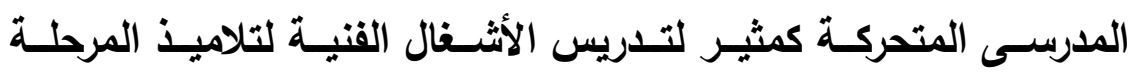
الإعدادية" يهدف البحث إلى استحداث صياغات تشكيلية للدمي المتحركة وخلفياتها للوصول إلى ابتكارات فنبة جديدة من خلال تدريس التربية الفنية

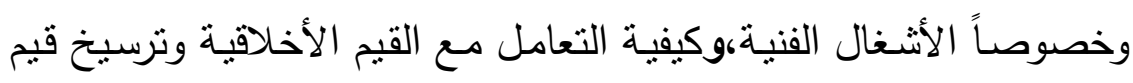

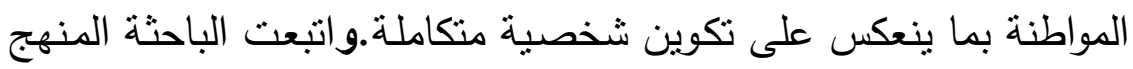
الوصفي التحليلي و المنهج التجريبي، وتمتلت عينـة البحث فى تجسيد شخصيات قصـة من قصص" ألف ليلة وليلة" ،والمرحلـة العمريـة لعينة

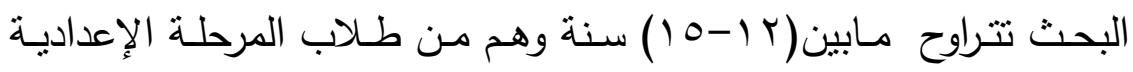

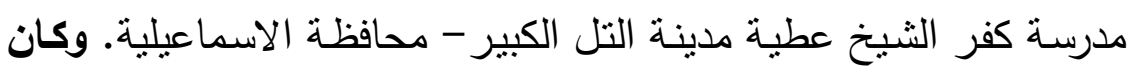
من أهم نتائج البحث :- إن مسرح الدمي يستطيع أن يحظى بدور نربوي الفئي 


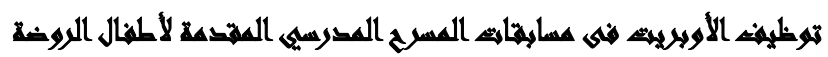

"عراسما تطليلية"

كبير في مجال تتشئة وتربية التلاميذ وفق المعايير والأسس العلمية السليمة التـي تتســم ومعطيـات بيئتهـه الوطنيـة وتدفعـهـ بإيجابيـة نحـو الإبـداع

(11). والتميز

r) دراسـة : نجـلاء محمد محمود محمود عبد الله (r ا • r م) بعنوان: "دور المسرح المدرسـى فى اكسـاب الأطفـال المعلومـات البيئية" تستهدف هذه الدراسة التعرف علي دور المسرح المدرسي في اكساب الأطفال المعلومات البيئية من خلال النصوص والعروض المسرحية المقدمة أثناء فترة الدراسـة وقد اتبعت الدراسـة منهج المسـح بالعينـة وفي إطـار ذلك قامت الباحثة. بتحليـل مضـمون عينـة مـن النصـوص والعـروض المسـرحية خـلال فتـرة

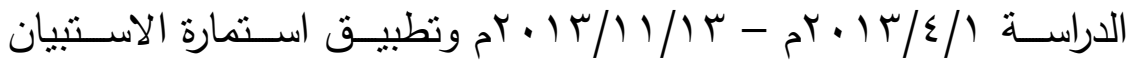
كواستمارة الحالـة الاقتصـادية علي عينـة مـن الاطفال "ذكور - إنـاث" فى

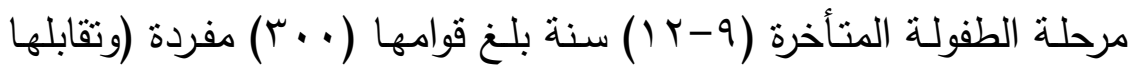
في الدراسة المرحلة الابتدائية).وكان من أهم نتائج الدراسـة وجود علاقة ارتباطية موجبة ذات دلالة إحصائية عند مستوي ا . . . بين كثافة تعرض الأطفال للمسرح المدرسي والمعلومات البيئية المكتسبة وهذا بعني أنه كلما زاد عدد مـرات مشـاهدة الأطفـال عينـة الدراسـة للعـروض المسـرحية التي تحمل في طياتها معلومات عن البيئة من حولها زاد مقدار هذه المعلومات

المكتسبة لديهم . (i) (1) - تعليـق عـام علـى الاربــات السـابقة: يمكن التعليق على نتـائج الاراسات السابقة من خلال المحاور الآتية : ا - المحسور الأول : تشـابهت دراسات كل من ستيفن ف. زدزنسكى وآخرون 


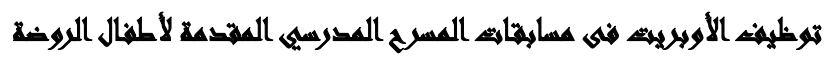

"عراسم تشليليه"

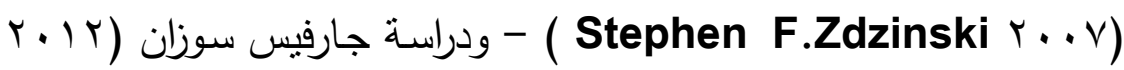
(Garvis, Susanne الأوبريت فى المسرح من خلال ضـرورة تسليط الضـوء على أهمية تعليم الفنون ضمن برامج مرحلة الطفولة المبكرة. r- المحور الثانى : بعد هذا العرض للدراسات السابقة العربية والأجنبية، لابد مـن توضـيح موقع هـذه الدراسـة مـن تلـك الدراسـات مـن حيـث التثـابه والاختناف، إذ أن نقاط التشـابه بينها تتمثل فـى الهدف، وهـو توظيف وتفعيل دور الأوبريت فى المسرحيات المدرسية ، كما اتفقت الدراسة الحالية مع دراسات كل من: - دراسة : علا حسن كامل سيد (V . . rم) - دراسة:

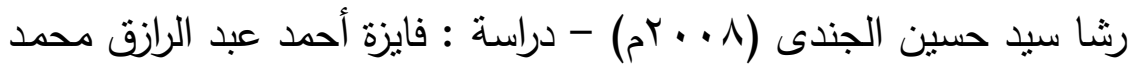

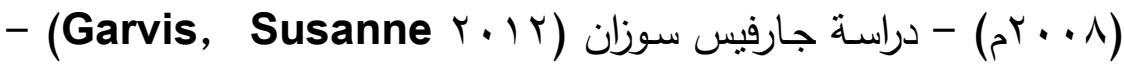

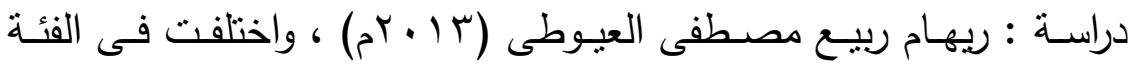
المستهدفة وهم أطفال الروضة.

r- المحور الثالث_: الاراسـات التحى تناولت نشـاط المسرح المدرسى هى : دراسة: أمل عادل كامل (9 . . rم) - دراسة : نورة عبد العزيز على محمد

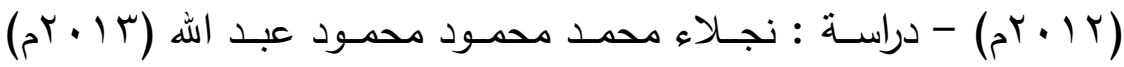

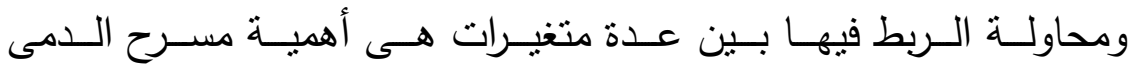
المدرسى،والأبعاد التربوية والجمالية للمسرح المدرسى، والمعلومات البيئية . - أوجه الإستفادة من الدراسات السابقة : الاستدلال على المشكلة البحنية وتحديدها،ووضع تساؤلات الدراسة. الاستفادة النظرية والتطبيقية من الدراسات السابقة. 


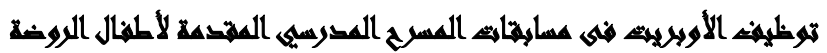

\section{"عراسمة تحليلية"}

ساعدت الباحثة فى اختيار المنهج المناسب للاراسة ومعرفة أهم المراجع العربية والأجنبية التى يمكن الاستعانة بها ـأبها ساعدت الباحثة على التأصيل النظرى للاراسة . الوفوف على بعض الجهود والمحاولات العربيـة والأجنبيـة التى بُذلت فى مجال الدراسة، والاستفادة من منهجها فى البحث وأهم النتائج التى توصلت

تحديد أوجـه التشـابه والاختـاف بين الدراسـات السـابقة والدراسـة الحاليـة، والذى يكمن فى أن الدراسات السـابقة تتاولت المسرح المدرسى فى علاقته بتلاميذ مرحلة الروضـة بمستوبيها الأول والثانى" وربطها ببعض المتغيرات بينمـا الدراسـة الحاليـة تتاولـت توظيـف الأوبربــت فـى مسـابقات المسـرح المدرسى المقدمة لأطفال الروضة وذلك من خلال الإطلاع على العديد من الخطـط والبـرامج الزمنيـة ولـوائح المسـابقات الخاصــة بالمسـرح المدرسـى المعنيـة بهذه الفئة، ومـن ثم يتضـح مدى إسـهام الدراسـة الحاليـة فى هذا

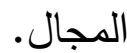
خلاصة القول أن الدراسة الحالية استفادت من الدراسات السابقة بأن بدأت من حيث انتهت تلك الدراسـات ،وخاصسةً أن دراسـة الأوبريت قى المسرح المدرسى لم يحظٌ بأى اهتمام من قبل الباحثين بمدارس روضـة الأطفال إذا ما قُورن بيقية الفنون الأخرى. ويعد أن تثاولت الباحثة الدراسات السابقة سوف تسير الدراسة وفقاً للخطوات

الإطار النظرى: وفى هذا الصدد سوف تقسم الباحثة بحثها إلى عدة محاور: 


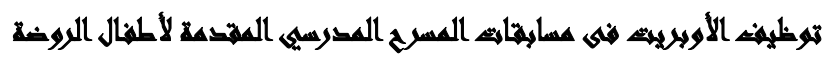

" قراسما تحليلهية"

المحور الأول : وتمثلت فى الأُطر النظرية للاراسة:

أولاً: الأوبريت (المفهوم- النشأة) - ثانياً: خصائص تلاميذ مرحلة الروضة. •المحور الثانى : الإطار المنهجى للدراسة.

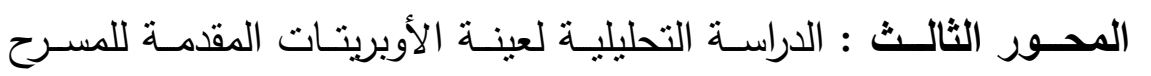

المدرسى (موضوع الدراسة) وعرض لنتائجها (تحليلها وتفسيرها).

المحور الأول : أولاً: الأويريت (المفهوم- النشأة)

إن الأوبريت كما نعرفها، وكما هـى معروفة بملامحها المتباينة، تُعتبر

ضحكة الموسيقى وابتسامتها، وهى تتألف عادة من ألحان موسيقية وغناء فردى وثتائى وثلاتى بالإضـافة إلى الرقص وإلى مقاطع متعددة يجرى فيها الحوار

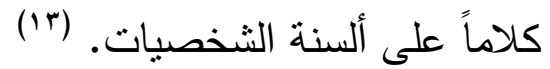

وهـى تصـغير لكلمـة أوبـرا، وهـى مسـرحية غنائيـة، تتتـاول موضـوعاً

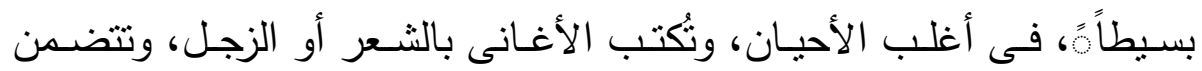

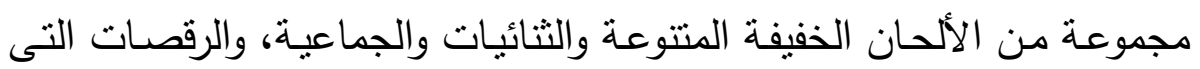

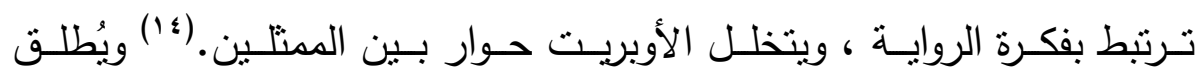
اصطلاح الأوبريت على المسرحية الخفيفة التى تجمع بين الحوار العادى وبين الثخصيات، والمقاطع الموسيقية والغنائية التى تعالج موضوع الحوار بأسلوب موسيقى مرح. (10)

وكانت تُشـير إلـى الأوبـرا القصـيرة، إلا أن مـلولها تغير فـى القرنين

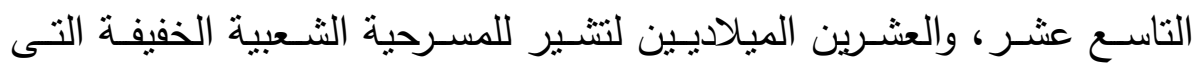
تتضـمن موسـيقى، وأغنيـات ورقصـات غيـر كلاسـيكية. (1') فهـى نـوع مـن المسرحيات الغنائية كان محبوباً في الفترة بين أواسط القرن التاسـع عثر حتى 


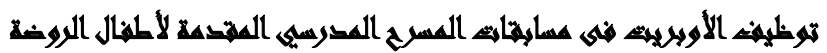

\section{"عراسما تبليلهية}

العشرينيات من القرن العشرين المبلادي. وتطور الأوبريت من الأوبرا الهزلية

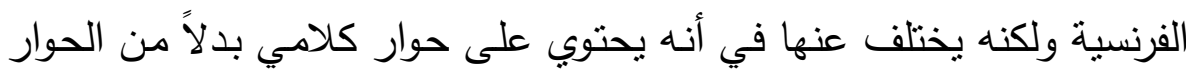

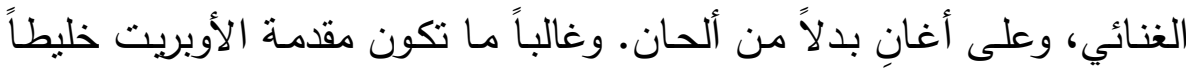

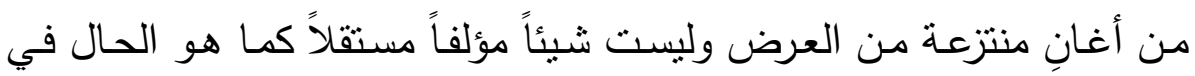

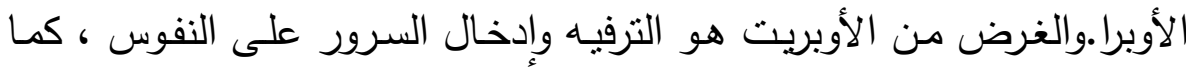

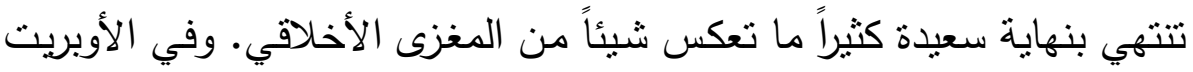

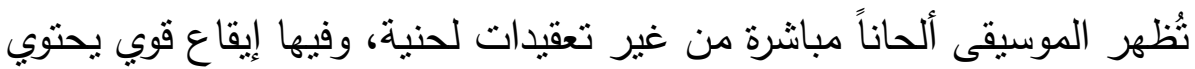

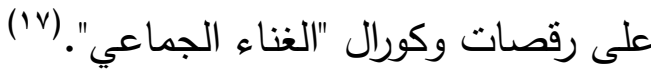

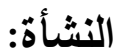

في العالم العربي انتشر فن الأوبريت نقلاً عن أوروبا ولكن بمزيد من التعريب ليلائم الفكر الثرقي والمتلقي في الثرق. وقد بدأ هذا اللون من المسرح الإنا

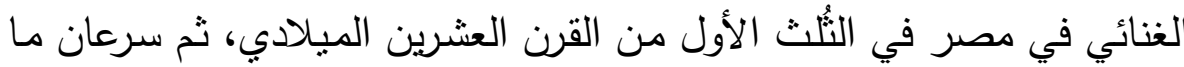
انتقل إلى بلدان عربية أخرى مثل لبنان وسورية وكان هناك تأثثر كبير لزيارة

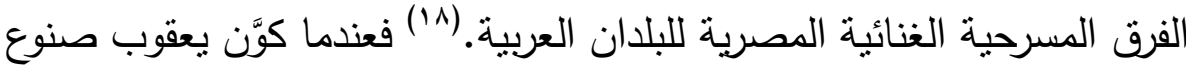

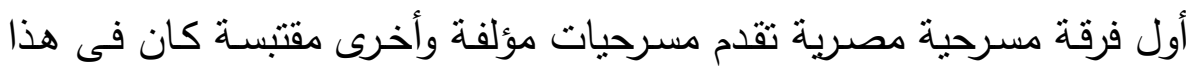
كله يصبغ مسرحياته بالصبغة العامية المصرية المحلية ويُضفى عليها الطابع الغنائى إلى جانب النكهة الفكاهيـة الانتقاديـة الضـاحكة. وهذا معناه أن رواد

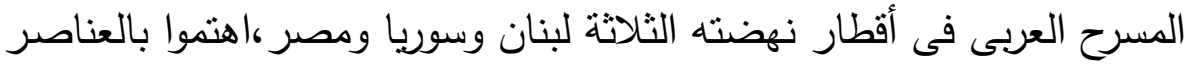

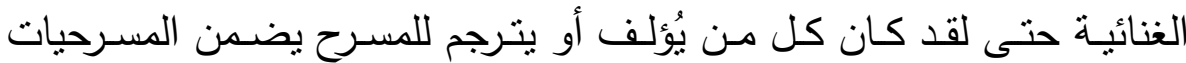
قصائد غنائية. ومضى المسرح العربى فى مصر على هذا النحو حتى انشق بنق سلامة حجازى عن أبى خليل القبانى الذى كون فرقة خاصـة اتجهت بالمسرح 


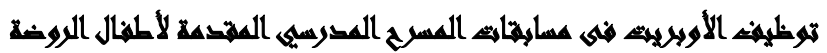

\section{"عراسما تطليلية"}

اتجاهاً غنائياً خالصاً. وأنشأ الثيخ سـلامة بدوره مسرحه الثهير "دار التشثيل

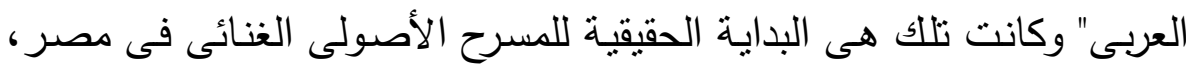
وشهر هذا المسرح روائع سلامة حجازى،وقد كان الجمهور يتهافت على مسرحها لسماع صوته. وحتى جورج أبيض الذى اشتهرت فرقته بطابعها التراجيدى كان يحرص على تقديم المسرحيات الغنائية باعتبارها اللون الملائم للمزاج المصرى.

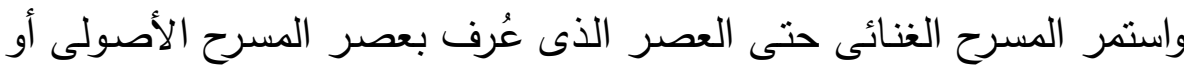

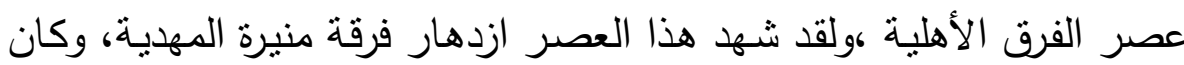

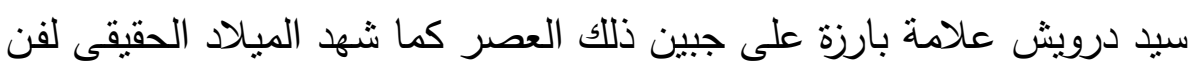
الأوبريت المسرحى، بعد أن كوَّن سيد درويش فرقته الخاصـة التى قدمت على دلى مسرح دار التمثيل العربى ثلاثثته الكبرى العشرة الطيبة وشهرزاد والباروكة فكان

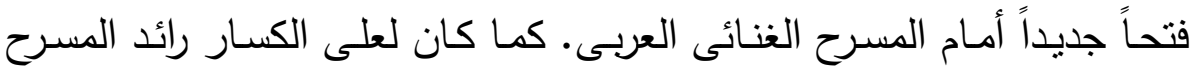

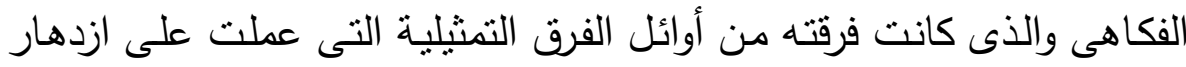
المسرح الغنائى وحشد للفرقات أشهر مطربات عضد عصره. تلك كانت مسيرة المسرح الغنائى قبل الثثورة وهى مسبرة باهرة، غير أنها مضت فى خطوط مترددة. تصعد تارة وتهبط ثانيـة بعد احتدام الفترة

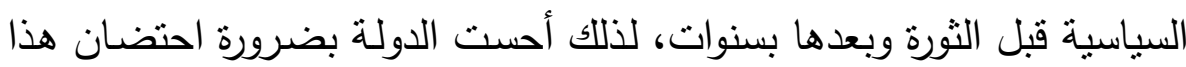

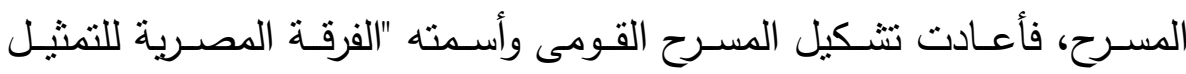

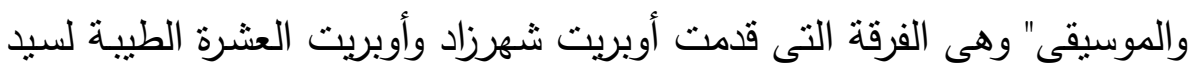
درويش وأوبريت يوم القيامة وأوبريت عزيزة ويونس لزكريا أحمد ثم أوبريت ليلة من ألف ليلة لبيرم التونسى وأحمد صدقى. 


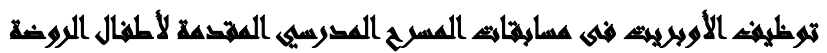

\section{"عراسما تشليلية"}

وعادت الروح إلى المسرح الغنائى فى عام 90 ام بعد أن احتضنته وزارة الثقافة وقدم له على أحمد بـاكثير وزكريـا الحجاوى تأليفاً ، وعبد الحليم

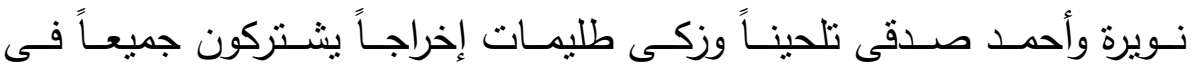
الاستعراض الغنـائى "ليـل يـا عين" والذى كان نـواة لظهور فرقة رضـا للفنون الثـعبية. وأنثـأت الـوزارة المسـرح الغنـائى عـام الو9 ام ، ثم أنثـئت الفرقـة الغنائية الاستعراضية عام ب 97 (م، وكان ذلك بمثابة تصحيح للمسار وترشيد

(19) للمسيرة

\section{أهداف تعليم الغناء فى مرحلة ما قبل المدرسة:}

يلعب الغناء دوراً هاماً فى تتميـة خصائص طفل ما قبل المدرسـة من جميع جوانبها،سواء كانت جسمية، أو عقلية، أو وجدانية، أو اجتماعية.وبمكن هئ أن نحدد هذه الأهداف فيما يلى جواء: التعرف على خصائص المثيرات المحيطة بالطفل. القدرة على إصدار الكلمات بدقة. زيادة الحصيلة اللغوية للأطفال. اكتساب المفاهيم،وتتمية الذاكرة. تكوين ميول إيجابية نحو ذات الطفل ونحو بيئنه ونحو الموسيقى. تكوين القيم والعادات السوية سواء صحية أو دينية أو إجتماعية. تعويد الطفل على المشاركة الاجتماعية والتعاون والإحساس بالدور . تحقيق التفاهم الدولى عن طريق غناء أغانى الثعوب المختلفة.(r)

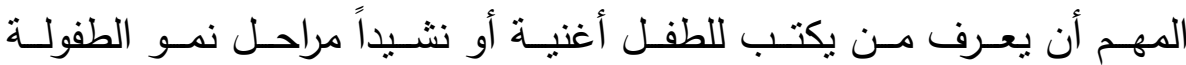
وخصائص كل مرحلة ومطالب نموها وحاجات الطفل النفسية فى كل مرحلة، 


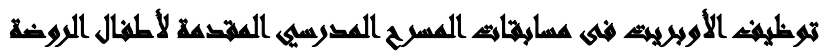

\section{"عراسمة تحليلية"}

هذا بالإضـافة إلى معرفـة معجمه اللغوى خـلال هذه المراحل. وعلى هذا فإن الموهبة الأدبية وحدها لا تكفى لمن يكتب أدباً للطفل، لأن أغنبة الطفل يمكن هُهن أن يكـون لهـا قيمـة كبيـرة فـى حياتـه، أو أهـداف عديـدة إلى جانـب الإمتـاع

والاستمتاع عند سماعها. (r)

\section{ثانياً :خصائص تلاميذ مرحلة الروضة}

تُعتبر السنوات الأولى من حياة الطفل من أهم مراحل الحياة وأكثرها

تأثيراً في مستقبل الإنسان، فهي مرحلة نكوينية يوضع فيها الأسـاس لشخصيته ويكتسب فيها عاداته وأنماط سلوكه المختلفة، كما أن كل ما يتعرض لـه من فن لهن خبرات وعلاقات وتفاعلات يكون لها أثرها على اتجاهاته المستقبلية. "وتُعتبر مرحلـة ريـاض الأطفـال مرحلـة إعداد وتهيئة للطفل بالنسـبة لحياتـه الدراسـية المقبلة وكل تخطيط فى الروضـة يجب أن يقوم على هذا الأسـاس فالطفل فى فره هذه المرحلة فى حاجة إلى توفير المناخ الملائم الذى يكثف عن قدرات الطفل ومواهبه ويساعد على التفكير المنظم الهادف ويعتتى بصحته الجسمية والنفسية العناية اللازمة، كما بعمل على إزالة ما قد يعتريه من خوف أو رهبة حين بترك

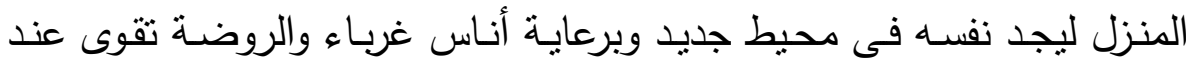
الطفل عامل الثـاعة والجرأة وتجعله أكثر انطباعاً وأقرب إلى اتباع النظام وأكثر تقبلاًا. (rr) ويُضيف حامد زهران فى تقسيمه لمراحل النمـو" أن مرحلـة الطفولة المبكرة تضم سنوات (r،ع، ه) وهى ما بُطلق عليها تربوباً مرحلة ما قبل المدرسة + الروضة". (r) وقد أثبتت الدراسـات التربويـة أن الطفل الذى يلتحق بريـاض الأطفال تتمو لديه العديد من المواهب والقدرات التى لا تتوافر لمن حُرموا من الالتحاق 


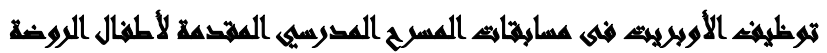

\section{"عرامسا تطليلهي"}

برياض الأطفال؛ لأنها يمارس العديد من الهوايات والأنشطة النى تتميهم نمواً

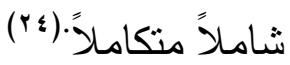

"لهذا تتضح بجلاء أهمية التعليم قبل المدرسى ، وتأثير خبرات الطفل

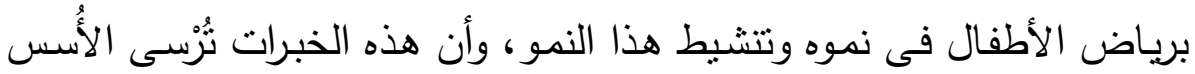
التى يقوم عليها بناء الثخصية كما تظهر تمكنه السريع من الخبرات الحركية ومن الاتساق الحركى الحسى. وأن الطفل - بتأثثر الروضـة - يُيدى نُضجاً

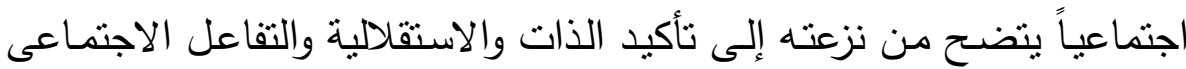

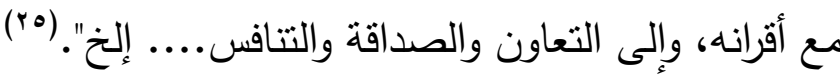

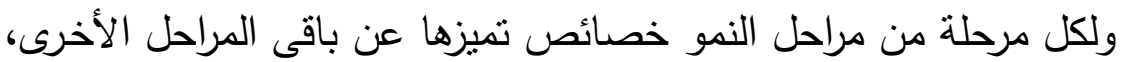

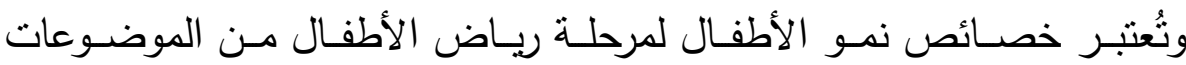

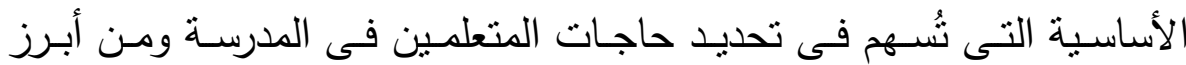
خصائص النمو لمرحلة رياض الأطفال:-

\section{1 - خصائص النمو الجسمى Physical Development}

يتضمن النمو الجسمى التغير التشريحى كماً وكيفاً وكماً وشكلاً ووضعاً ونسيجاً. والنمو الجسمى فى هذه المرحة مهم من ناحيـة الزيادة فى الطول

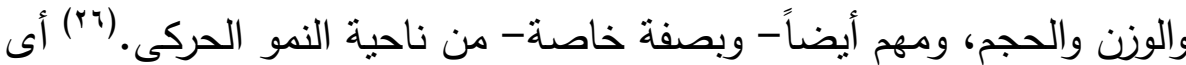

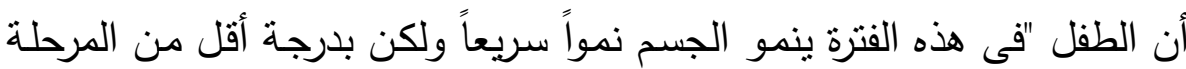

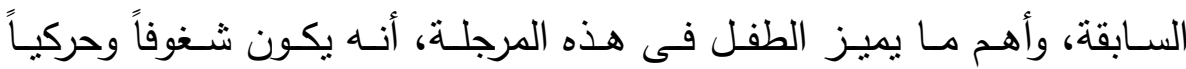

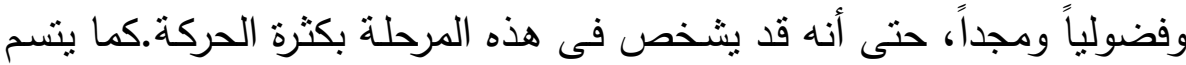
طفل هذه المرحلة بمهاراته فى استعمال يديه، إلا أن قدرته على تأدية العمل العله

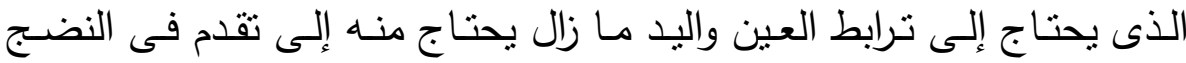




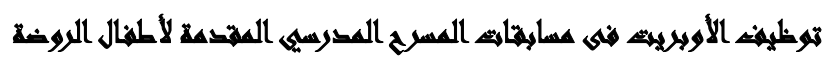

\section{"عراسمة تحليلية"}

والتدريب".(rV) وبُناءً على ذللك فلابد من توفير الأنشطة التى تنتلأم مـع ميول الطفل لتتمية مهاراته اليدوية، وتنمية قدرته على اللصق والرسم والتلوين ....إلخ Y Y خ خائص النمو العقلى Intellectual Development تتميز المرحلة بتمتع الطفل بمهارة عالية فى اللغة، وحب التكلم عند معظم الأطفال وبخاصـة أمسام مجموعة، كما أن قدرتى التخيل والابتكار تكونـان فى قمتها فى هذه المرحلة، ولذلك يجب أن ثُنمى هذه القدرات من خـل اللعب والرسم وقص القصص وإلى غير ذلك من أنشطة منتوعة.(^^) والتخيل عملية عقلية تعتمد على تكوين علاقات جديدة بين خبرات سابقة بحيث تتنظم هذه الخبرات فى أشكال وصور جديدة لم يألفها الفرد من قبل والتخيل يصل بين ماضسى الطفل وحاضـره ويمتد إلى مستقبله ولذلك فهو أسـاس للإبداع الفنى والابتكار والتكييف مـع البيئة .(9) ويُطلق البعض على هذه المرحلة " مرحلة السؤال، فمـا أكثر أسئلة الطفل فى هذه المرحلة، إنك تسمع منهـ دائمـاً مـاذا؟، لماذا؟، متى؟،أين؟، كيف؟، من؟....إلخ. ويكون الطفل فى هذه المرحلة علامـة استقهام حيـة بالنسبة لكل شىء، فهو يحاول الاستزادة العقلية المعرفيـة، وهو يريد أن يعرف الأشياء التى تثير انتباهـه، ويريد أن يفهم الخبرات التى يمر

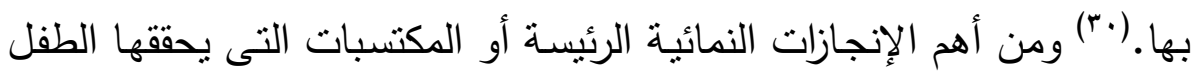
خـلال هـذه المرحلـة هـى الإدراك ( الأثـكال والألـوان، والعلاقـات المكانيـة،

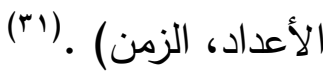

r- خصائص النمو الانفعالى Emotional Development وتعد فترة ما قبل المدرسة مرحلة هامة فى النمو الانفعالى للطفل، بقدر ما تأخذ انفعالات الطفل فى تلك الفترة فى التعدد والتعميم، يتصف النمو فى هذا 


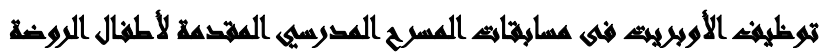

\section{"عراسما تطليلية"}

الجانب بالانفعالية المرتفعة التى تتصف بثورات الغضب، وبالمخاوف الثديدة

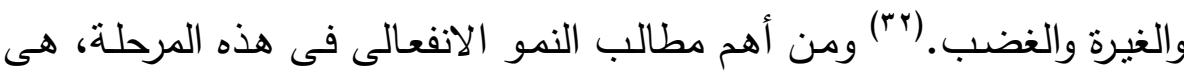
الحاجة إلى الثعور بالأمن والاطمئنان والقبول، ليستطيع أن يعبر عن انفعالاته

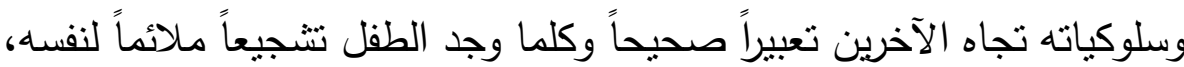

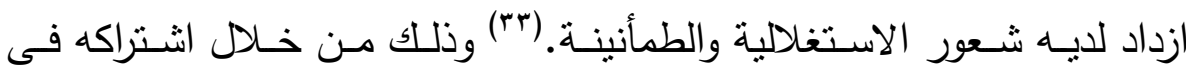
الأنشطة المتنوعة السارة، التى تتيح للطفل الفرصة للتمثيل واللعب والغناء والتى لتى تبعث المرح والسرور فى نفوس الأطفال مما تتيح لهم فرص التنفيس والتعبير

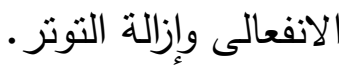

\section{Social Development خصائص النمو الاجتماعى}

من أهم مطالب النمو الاجتماعى فى هذه المرحلة أن يتعلم الطفل كيف يعيش مـع نفسـه، وكيف يعيش فى عالم يتفاعل فيـه مع غيره من الناس ومـع

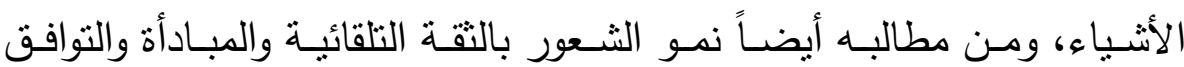

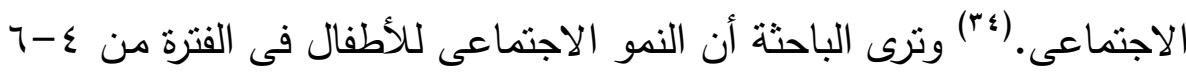
سنوات يتطور تطوراً متميزاً يتضـح فى عدد من المظاهر ، من أبرزهـا تزايد اتصـالات وعلاقـات الطفل مـع أقرانـه وإدراكه لبيئته وتفاعله معها. كمـا تقيد الروضـة فـى تأكيـد الـذات عنـــ الطفـل، والاعتمـاد على الـفس والاسـتقلال والاتصــال الجمـاعى. مـع أقرانــه كمـا تُشـهم فـى توافـق الطفـل الثخصـى والاجتماعى الناجح، وتعمل على تحسين عملية التشنئة الاجتماعية،فلابد وأن يشعر الطفل بثقته بنفسـ، وتأكيد لذاته وذلك من خلال المشاركة فى الأنشطة الجماعية التى تُسهم فى تشجيعه على التعاون. 


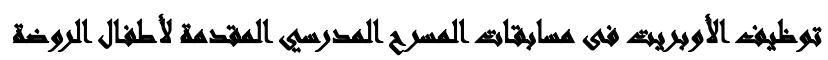

\section{"عراسمة تطليلية"}

ومن المظاهر الأساسية للنمو الاجتماعى فى تلك المرحلة هو" تغير نمط اللعب

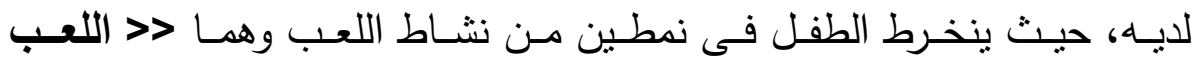
المتـوازى>> أى( يلعـب إلى جـوار الأطفال الآخرين الذين يستخدمون نفس

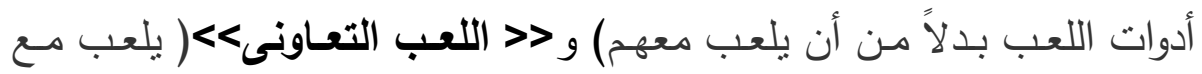
الآخرين ويشاطرهم أدوات اللعب)" ـ (ro(

وفيما يلى ملخص لبعض مظاهر النمو الاجتماعى فى تلك المرحلة: اتساع دائرة العلاقات والتفاعل الاجتماعى فى الأسرة ومع جماعة الرفاق. هتعلم الطفل المعايير الاجتماعيـة التهى تبلور الدور الاجتمـاعى لله وبيدأ الطفل بتمسمك ببعض القيم الأخلاقية والمبادىء والمعايير الاجتماعية. تتمو الصداقة حيث يستطيع الطفل أن يصادق اللآخرين ويلعب معهم. يميل إلى المنافسة و ينمو الاستقلال. ينمو الضمير ويتضمن الإحساس بما هو حسن أو خيراً أو حلال وما هو لإلى

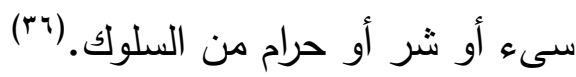

هoral Development خصائص النمو الخلقى فى هذه المرحلة، لا يصل النمو العقلى للطفل بعد إلى درجة، تسمح لـه بتعلم المبادىء الخلقيـة المجردة فيمـا يتعلق بالصـواب والخطأ، ولكنـه بيتطيع بالتدريج أن يتعلم ذلك فى مواقف الحيـاة اليوميـة العمليـة. ويلاحظ أن ذاكرة الطفل لا تسـاعد بعد على الاحتفاظ بتعليمات ومبـادىء السـلوك الخلقى مـن موقف لآخر ، وما زالت قدرته على تعميم مـا يتعلمهـ من موقف لموقف آخر محدودة. (rv) فالطفل شيئاً فنشيئًا أثناء نموه النفسى والحركى يكتسب الوعى بالقيم 


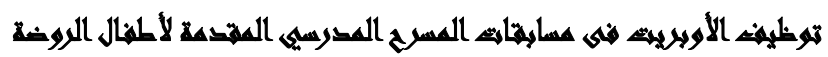

"كراسما تطليلية"

وضـرورة الالتزام بها عن طريـق التجربـة وتوجيـه الآبـاء والأمهات والمعلمينين والأشخاص المهمين بالنسبة له.

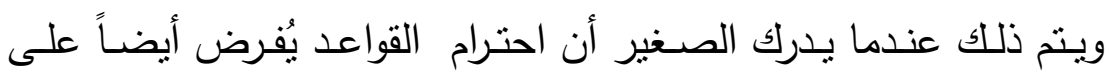
الآخرين،وأن ذلك يعود عليه بـالنفع هو أيضـاً،ومن هنا يتأكد فكرة أن القاعدة الحقيقية لها قيمة مستقلة عن الثخص وتكون صالحة بالنسبة للجميع. \- خصائص النمو اللغوى Linguistic Development هذه هى مرحلة أسرع نمو لغوى تحصيلاً وتعبيراً وفهماً. وللنمو اللغوى

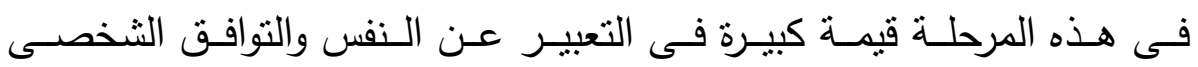
والاجتماعى والنمو العقلى. (r^) ويمكن إجمال التطورات الرئيسية للطقل فى تلك المرحلة فيما يلى : تظهر مهارات حركية قوية وجيدة وتزداد القوة.

السلوك متمركز حول الذات بدرجة كبيرة ولكنه يفهم آراء الآخرين. يؤدى عدم النضوج المعرفى إلى بعض الأفكار غير المنطقية عن العالم. ينضج اللعب، والإبداع، والتخيل، وبصبح أكثر اتقاناً . يزداد الاستقلال، والتحكم الذاتى، والاهتمام بالذات. ما زالت الأسرة هى محور الاهتمام بالرغم من أن الأطفال الآخرين أصبحوا

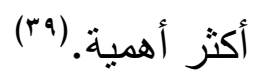

الإطار المنهجمى للاسراسة: المحور الثانى:

مشكثة الدراسة وتشاويلاتها : المسرح المدرسي مجال واسـع للجمع بين عدة فنون، كالرسم والنحت والتصوير وغيرها من الفنون، فهو ليس خشبة صماء ،وكلام جاف ، بل هو 


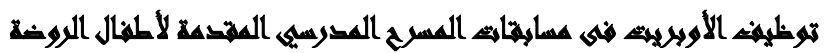

\section{"عراسما تطليلية"}

بوتقـة تتصـهر بـداخلها كل الفنون مـن موسيقى وديكور (الفنـون التتـكيلية)

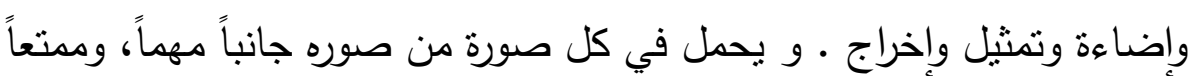

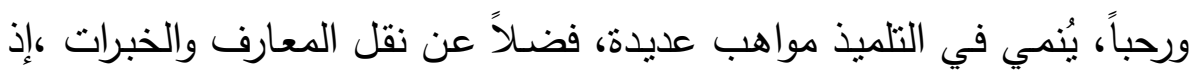

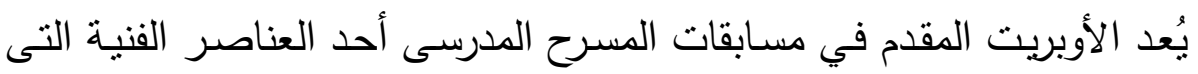

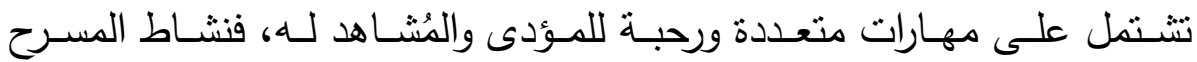

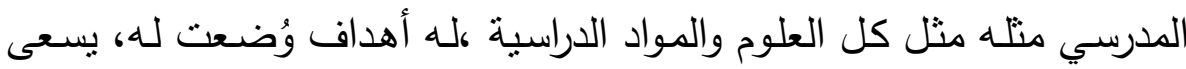

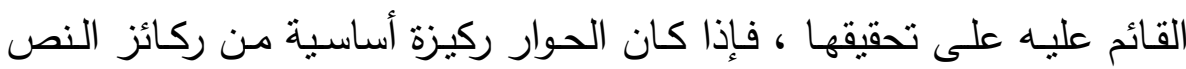

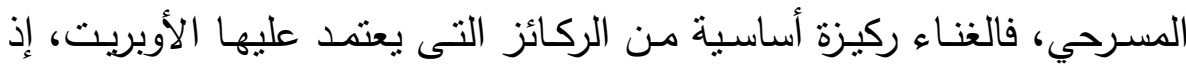

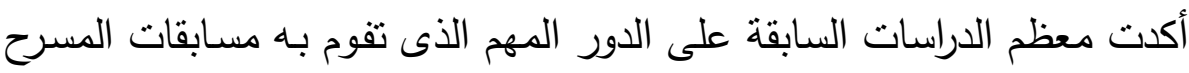

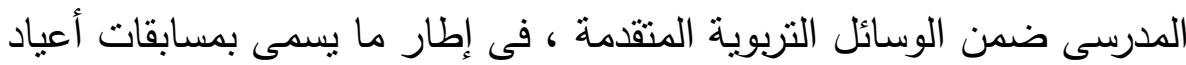

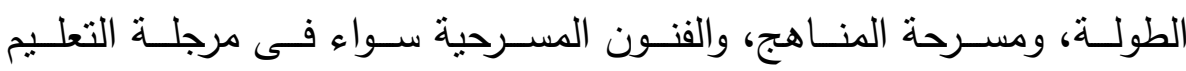

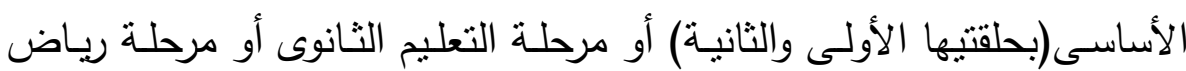

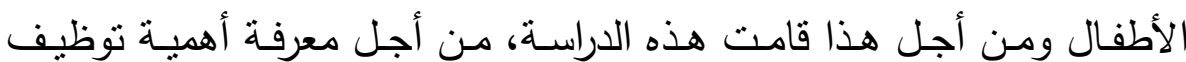
الأوبريت فى ثلاك الدسابقات الدقدمة لأطفال الروضة. ويمكن تحديــ مثـكلة الدراسـة الحاليـة في محاولـة الإجابـة على السـوأل

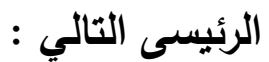

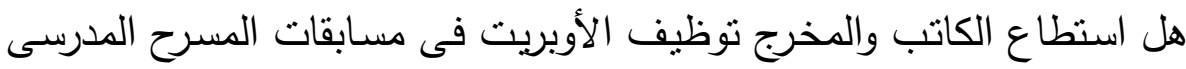
المقدمة لطفل الروضة؟ ويتفرع من هذا التساؤل عدد من التساؤلات الفرعيةٍ تثمل الارراسة التحليلية: (1) ما الثكل الأدبى الذى قُم به الأوبريت ؟

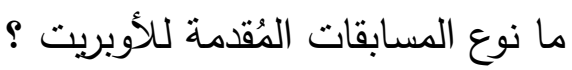




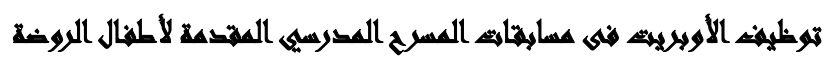

"عراسما تشليلهي"

(T) ما المرحلة العمرية التى يُخاطبها الأوبريت

(ع) ما الإطار الزمانى الذى يجرى فيه الأوبريت ؟

(0) ما الإطار المكانى الذى يجرى فيه الأوبريت ؟

(T) ما اللغة المُستخدمة فى تقديم الأوبريت ؟ (الإسى

ما المصدر الذى تُستمد منه فكرة الأوبريت (V)

(^) ما المجتمع الذى يتتاوله الأوبريت ؟ (ه)

(9) ما نوع المعلومات التى ظهرت فى مضمون الأوبربت ؟

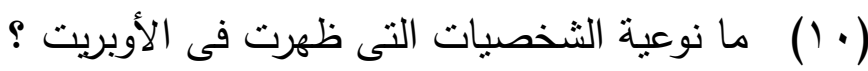

(1) (1) ما نوعية الأغنيات التى تتاولها الأوبريت ؟ (1)

؟ ما أسلوب تقديم الموسيقى فى الأوبريت (T)

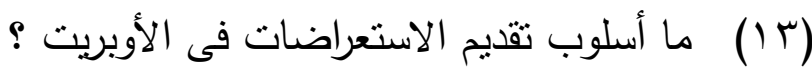

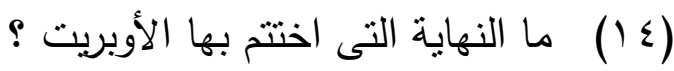

أهداف الاراسـة: وتثمثل أهـاف الدراسـة التحليلبـة في التعرف

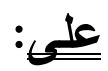

(1) الثكل الأدبى الذى قُدم به الأوبريت.

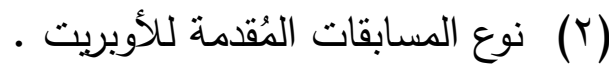

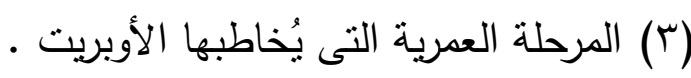

(ع) الإطار الزمانى الذى يجرى فيه الأوبريت . الذئ.

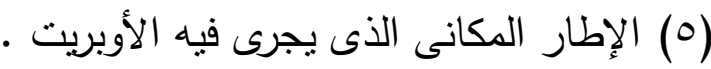

(T) اللغة المُستخدمة فى تقديم الأوبريت . الإطل

. المصدر الذى تُشتمد منه فكرة الأوبريت (V) 


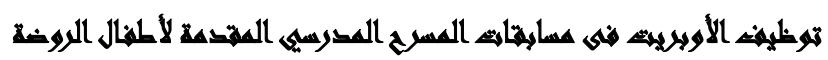

"عراسما تشليلهية"

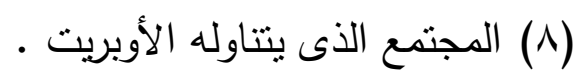

(9) نوع المعلومات التى ظهرت فى مضمون الأوبربت .

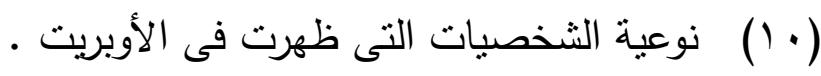

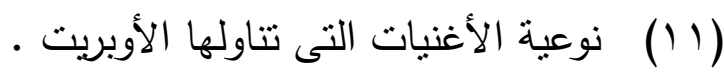

( أسلوب تقديم الموسيقى فى الأوبريت (T)

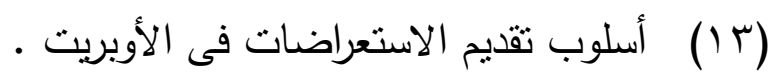

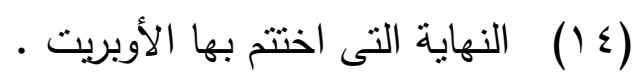

(0) بُناء على ما تتوصل إلبه الدراسة من نتائج ، يمكن رصد مجموعة من التوصيات العامة والمتخصصـة التى تقيد القائمين على المسرح المدرسى

ورياض الأطفال - و

أهمية الدراسة : تكمن أهمبة الدراسة الحالية فيما لـي :

ا ـ توضيح دور الأنشطة المسرحية المختلفة في تتمية بعض الجوانب لطفل الروضة.

r. أهميـة المرحلـة العمربـة التىى تتناولها الدراسـة وهـى مرحلـة الروضــة حيث يتسم طفل هذه المرحلة بالواقعية والخيال المحدود.

r. أهمية موضوع الدراسة حيث يتتاول طبيعة العلاقة بين الأوبريت والأنشطة المدرسية المسرحية وأطفال الروضة.

ع. تكتسب الدراسـة أهميتها من تحليل مضمون عينـة من الأوبريتات المقدمة فى مسابقات المسرح المدرسى وإبراز ما تحمله من مؤشرات تربوية تُخاطب عقل الطفل بسهولة ويُسر • 


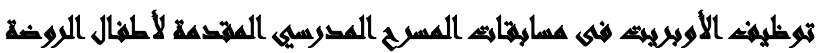

"عراسما تشليلية"

ه. لفت أنظار المهتمين بمرحلة رياض الأطفال بتزويد الأنشطة التعليمية التي تساعد على تتمية الحس الفنى لدى طفل الروضة . T. لفـت أنظـار المهتمـين بمرحلـة ريـاض الأطفـال بتقديم أنثـطة مسـرحية وموسيقية وغنائية تعمل على تتمية بعض جوانب الثخصية لديهم. V. الكثف المبكر عن الأطفال ذوي الحس التمثيلى والغنائى المسرحى في مرحلة رياض الأطفال والعمل على تتميتها وتوجيه نظر المرتمين والقائمين على تربيـة الأطفـال ورعـايتهم (أى تتشـيط مواهـب الطفـل فـى الغنــاء والتمثيل) ^. الاستفادة من نتائج هذه الدراسة في أنه يمكن رصد مجموعة من التوصيات العامـة والمتخصصـة التى تقيد القـائمين على المسـرح المدرسـى وريـاض - الأطفال - العطال

\section{: منهج الدراسة} تقع هذه الدراسة فى إطار المنهج الوصفى - المسحى الذى يستهدف دراسـة خصائص ظاهرة معينة أو موقف ما تغلب عليه صفة التحديد،وذلك عن طريق جمـع البيانـات والمعلومـات حـول الظـاهرة وجدولتها وتبوييهـا ثم تفسير تلك

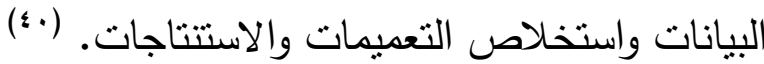
حدود الدراسة : لكل دراسة حدود علمبة نقف عندها، وتتمثل حدود

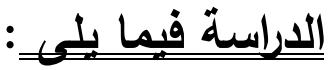

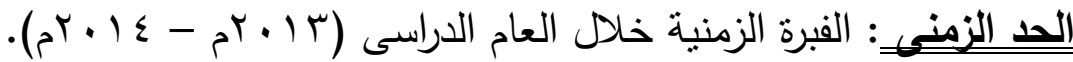
الحد البشري : أطفال المرحلة العمرية من (ع -7) سنوات(kg1-kg). الحد المكانى: بعض إدارات التربية والتعليم التابعة لمحافظة القليوبية. 


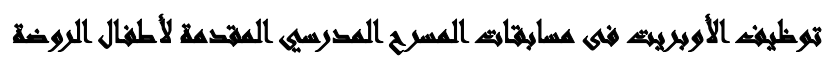

"عراسما تشليلهية"

الحد الموضوعى: دراسـة تحليلية لتوظيف الأوبريت فى مسابقات المسرح المدرسي المقدمة لأطفال الروضة . عينة الاراسة :

العينـة جزء من مجتمـع الدراسـة وتُمثنل مجتمـع الدراسـة تمثنيلاً صـادقاً،ولهذا يمكن تعميم النتائج على مجتمع الدراسة بأكمله (1؛) هولذا قامت الباحثة بإجراء الدراسـة التحليلية بعد إجراء الدراسـة الاستطلاعية "المبدئية" ل للمسابقات التى

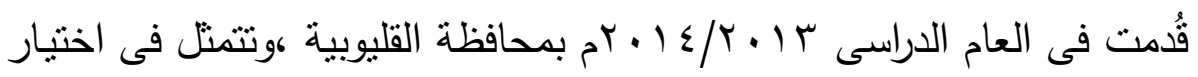

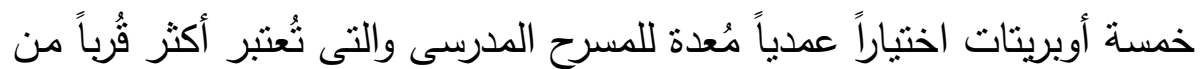
تحقيـق أهداف الدراسـة وهـى أوبريتـات ( إثـارات المـرور - الحروف تنتكلم -

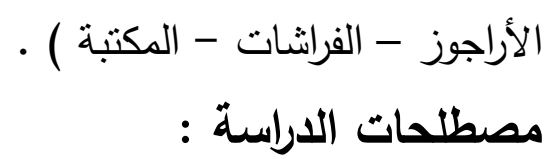

\section{Operetta الأويريت}

بـالمعنى اللفظى، الأوبريت هـى أوبرا صغيرة،لكنها طبعاً تختلف فنياً عن

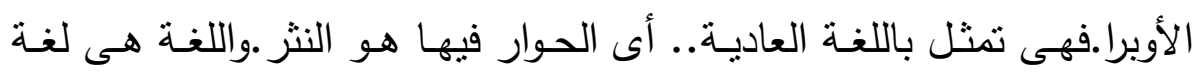
الحديث العادية فى الحياة،كما أن ألحانها أكثر سهولة من ألحان الأوبرا فهى تعتمد على ألحان(المدن الكبرى))إن صح هذا التعبير .أى الألحان الثـائعة بين

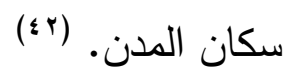
School Theatre contests مسابقات المسرح المدرسي وتُعرفها الباحثة إجرائياً بأنها "مجموعة المسابقات المنوطة بنشـاط المسرح المدرسى مثل مسابقة أعياد الطفولة للمراحل الدنيا من التعليم العام والأساسي والتى تضم موضوعات تربوية هادفة ومسابقة مسرحة المناهج ليتسنى للنشاط 


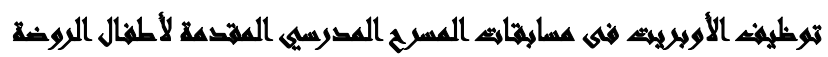

\section{"عراسمة تطليلية"}

المشـاركة الإيجابيـة في مسـرحة المنـاهج المدرسـية لطـلاب المراحل المختلفـة ومسـابقة فن الإلقاء والتحدث باللغـة العربيـة الفصـى على مختلف المراحل ومسابقة الفنون المسرحية".

\section{Kindergarten Children أطفال الروضة}

وتُعرفها الباحثة إجرائياً بأنها "المرحلـة العمريـة من (ع-7 سنوات) أو مـا

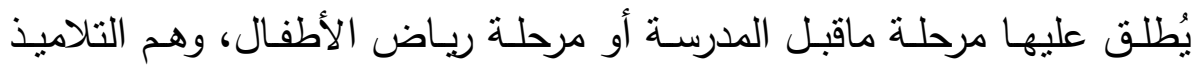
الذكور والإنـاث فى المدارس الرسمية التابعـة لوزارة التربية والتعليم بمستوبيها

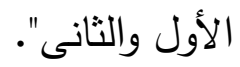
أدوات الدراسة :

اســتخدمت الباحثـة أداة تحليـل المضـمون كـأداة لجمـع البيانـات لتحليـل

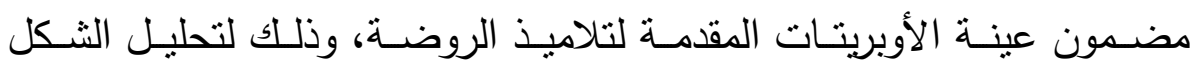
• والمضمون لهذه الأوبريتات - تحديد فئات تحليل المضمون: وهذه الفئات عبارة عن مجموعة من التصنيفات التى تقوم الباحثة بإعدادها تبعاً لمحتوى المضمون، ويتم ذلك بموضوعية، مما يتيح عملية استخراج النتائج بأسلوب علمى سليم •والتى تم على أساسـها جمـع المعلومـات فقد تـم اختيـار التقسيم التالى ليصنف تحته مضمون الأوبريتات: أولاً: فئات الشكل (كبف قيل) ؟

وهى فئات تخنص بالثكل الفنى الذى كُتب بـه الأوبربت، وتتقسم هذه الفئات الرئيسية إلى الأبعاد التالية: 


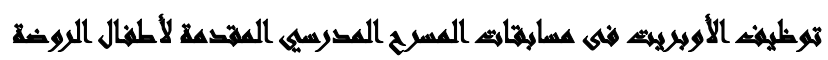

\section{"عراسمة تطليلية"}

(1) الثـكل الأدبى للأوبريـت عروض منهجيـة (مسرحة منـاهج) / مسـرحية

$$
\text { تربوبة عامة. }
$$

نـوع المسـابقات المُقدمـة للأوبريــت مسـابقة العـروض المنهجيـة مسـرحة

المناهج/ مسابقة الفنون المسرحية / مسابقة أعياد الطفولة.

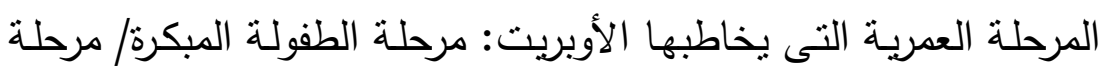

$$
\text { الطفولة المتأخرة/ لم تُحدد. }
$$

الإطار الزمانى الذى يجرى فيه الأوبريت: قديم/ حديث/ معاصر •

الإطـار المكانى الذى يجـرى فيـه الأوبريـت: فنـاء مدرسـة/ مسـرح/ غير الإسر

$$
\text { مُحدد. }
$$

اللغة المُستخدمة فى تقديم الأوبربت : اللغة العربية الفصحى المبسطة/

$$
\text { اللهجة العامية/ لغة تجمع بين الفصحى والعامية. }
$$

$$
\text { ثانياً: فئنات المضمون (ماذا قيل) ؟ }
$$

وهى فئات ترتبط بمضمون أو محتوى الأوبريتات،وتتقسم هذه الفئات الرئيسية إلى الأبعاد التالية:

(1) المصدر الذى تُستمد منه فكرة الأوبريت: أفكار عامـة /المنهج الدراسى/

$$
\text { مصادر أخرى. }
$$

(Y) المجتمـع الــى بيتاولـه الأوبريـت : المجتمـع المصـرى عمومـاً / المجتمـع

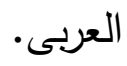

(r) نوع المعلومات التى ظهرت فى مضمون الأوبريت: المعلومـات العلميـة| المعلومات الدينية/ المعلومات الجمالية. 


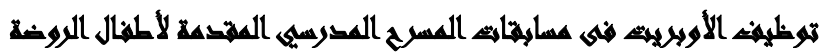

\section{"عراسمة تحليلية"}

(ع) نوعية الشخصيات التى ظهرت فى الأوبريت: أطفال/ كبار / شخصيات

$$
\text { أخرى. }
$$

(0) نوعيـة الأغنيـات التى تتاولها الأوبربـت : أغـانى فرديـة (solo) / أغـانى

$$
\text { جماعية/ أغانى فردية وجماعية (مشتركة). }
$$

أسـلوب تقديم الموسيقى فـى الأوبربت : موسيقى مُؤلفـة (حيـة) /موسيقى

$$
\text { مُقتبسة (مُسجلة)/ موسيقى تجمع بين الإثنين. }
$$

(V) جماعية استعراضات تجمع بين الإثنين. (^) النهاية التى اختتم بها الأوبريت : نهاية منطقية / نهاية غير منطقية. - تحديا وحدات تحليل المضمون:

"هى عبارة عن الوحدات التى يتم على أساسها العد والقياس مباشرة" (ז؛) ولتحليل المضـون يمكن الاستعانة بوحدات كثيرة وفى الدراسـة الحاليـة قامت الباحثة باختيـار الموضـوع كوحدة للتحليل فى هذه الدراسـة، حيث تُعتبر أهم وحدات التحليل حتى يتسنى دراستها واستخلاص النتائج منها. - إجراعات الثبات والصدق للاراسة التحليلية : بعد تصميم استمارة التحليل، قامت الباحثة بإجراء اختبارى الصدق والثبات، للتأكد من صلاحية الاستمارة للتطبيق فى تحليل البيانات.

ويعنى دراسة مدى مُلاعمة الأسلوب المُستخدم فى قياس الموضوعات التى يسـعى القـائم بالتحليـل إلىى قياسـها. وللتأكـد مـن صـدق الاسـتمارة الظـاهرى والمحتوى معاً تم عرض استمارة تحليل المضمون على بعض المحكمين فى لهى 


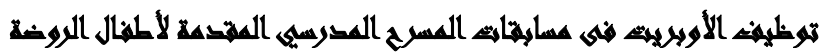

\section{"عراسمة تحليلية"}

مجالات الإعلام التربوى ، والمسرح ،والتربية (؛ ؛)ولقد بلغت نسبة الاتفاق بين المُحكمين 1 ^ \% مما يُشير إلى توافر الصدق بدرجة كبيرة. وذلك عن طريق حساب نسبة الاتفاق كالآتى =

\section{عدد الأسئلة المُتَفق عليها بلين المُحكمين}

\section{عدد محاور الاستمارة}

ومن خلا آراء وتعديلات المُحكمين تم صياغة الاستمارة فى صورتها النهائية بعد مـا أضـاف المُحكمون فئات معينة وحذفوا فئات أخرى، ثم قامت الباحثة بحساب مدى الاتقاق بينهم على بنود الاستمارة وإجراء التعديلات اللازمة لتكون الاستمارة فى صورتها النهائية وصالحة للإستخدام وتم على أساس ذلك تحليل مضمون عينة الأوبريتات عينة الدراسة.

\section{- مeبات التحليل : Reliability}

ويُقصد بـه ضرورة الوصسول إلى اتفاق كامل فى نفس النتائج بين الباحثين الذين يستخدمون نفس الأسس والأساليب على نفس المادة الإعلامية وإن كان يصعب تحقيق هذا الاتفاق الكامل من الناحية العملية لاحتمال تسرب الخطأ إلى أى مرحلة من المراحل أو تدخل قدر من الذاتية فيها.(ه؛) وللتأكد من ثبات الأداة فإن الباحثة تختار أسلوب للاختبار من بين الأساليب أو الاختبارات التى هن بتت من خلالها التأكد من ثبات التحليل، "ومنها طريقة إعادة الاختبار وطريقة

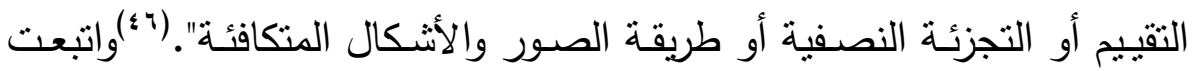
الباحثنة فى هذه الدراسـة طريقة إعـادة التطبيقة، ولحسـاب معامل الثبات بين

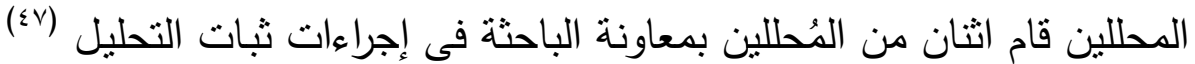
حيث لا يمكن التقة فى نتائج مُحلل واحد لعدم توفر الموضوعية من خلاله ، 


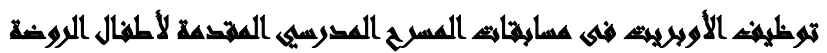

\section{"عراسها تيليليه"}

ويمكن اختبـار الموضـوعية مسن خـلال حسـاب درجـة الاتفـاق وتتطلب نسـبة

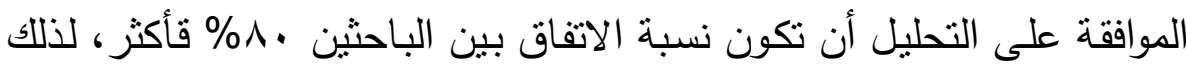
قامت الباحثة بإجراء ثبات الباحثة مع نفسها أولاً، وتم حساب معامل الثبات بين

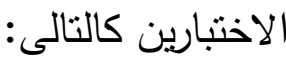

$$
\begin{aligned}
& \text { ith } 72 \times t \quad 5 \\
& .9 Y={ }_{-}={ }_{-}= \\
& \text {10. Vo+vo rut }
\end{aligned}
$$

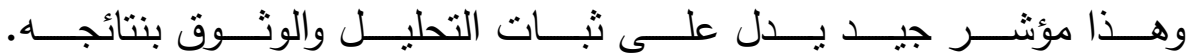
حيث م هى عدد الفئات المتفق عليها فى الاختبارين. ن (، ن Y هـى مجموع الفئات التى حُللت ، وبعد ذلك أجرت الباحنة اختبار الثبات مع المُحللين بعد تزويد كل مُحلل بوحدات التحليل والتعريفات الإجرائية

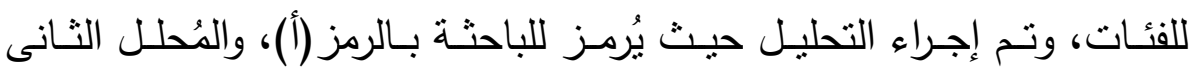
بالرمز (ب)، والمُحلل الثالث بالرمز (ج)، وبذلك تكون معاملات الثبات كالتالى:

$$
\begin{aligned}
& \text { أكب = } \\
& .91={ }_{-}={ }_{-}= \\
& \text {10. Vo vo viti } \\
& \text { أl } \\
& . .90={ }_{-}={ }_{-}= \\
& \text {10. Vo+Vo }
\end{aligned}
$$




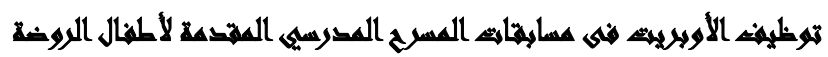

"عراسما تشليلهية"

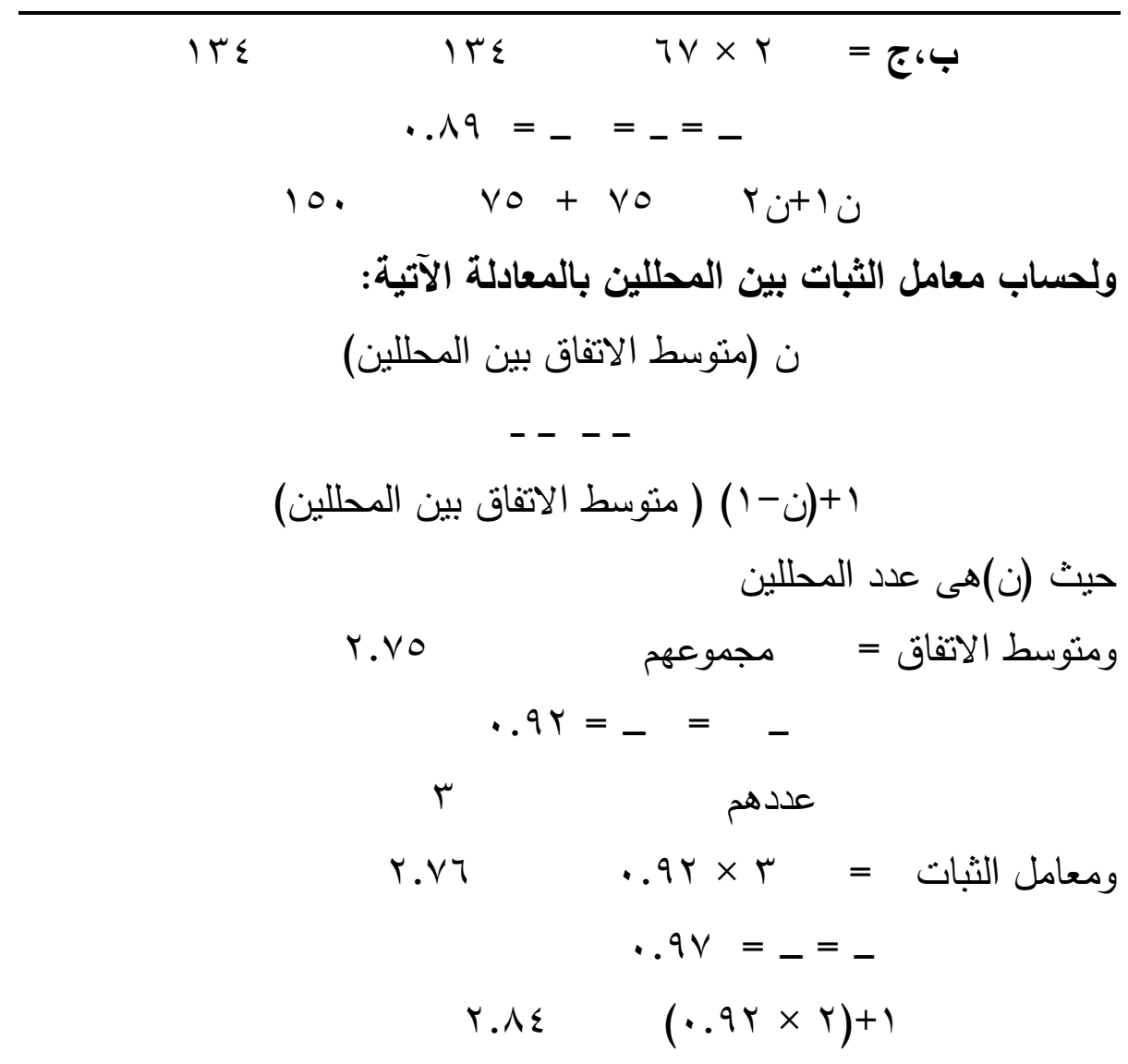

وبتضح من هذه النتائج أن عمليات التحليل التى اعتمدت على استمارة تحليل المضدون وفئاتها يمكن الوثوق بنتائجها بدرجة كافية. - الأساليب الإحصائية المستخدمة : الإنة لاسـتخراج النتائج الخاصـة بالدراسـة التحليليـة اعتمـدت الباحثة فى عمليـات التحليل الإحصائى لهذه الدراسة على التكرارات البسيطة والنسب المئوية . المحور الثالث : الاراسة التحليلة : التيلية (أويريث إشارات المرور (^ء) 


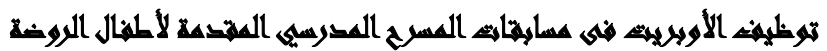

\section{"عراسمة تحليلية"}

الفكرة : الأوبريت يتتاول إثارات المرور وألوانها وكيفية استخدامها.

نـوع المسـابقة: مسـرحة منـاهج ، مدرسـة شوقى يونس التجريبيـة ، إدارة شبين $\cdot{ }^{0}+1 \leq 6$

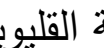
ة تة، محافظ القن

الموسيقى : تأليف أ/عاطف عطا موجه الأنشطة والحفلات بالمدرسة. الهرف : هو تزويد وتعليم تلاميذ مرحلة رياض الأطفال ما يلى: - - معرفة جهة اليمين وجهة اليسار والنظر فى كلا الإتجاهين قبل العبور • - معرفة مـا يترتب على مخالفة إثـارات وقواعد المرور وعدم المشىى الآمن فى الطريق.

- - اتباع القوانين والقواعد واحترام النظام والمرور جيداً حتى لا تسبب الخطر للك ولغيرك ومعرفة أهمية اتبـاع تلك القواعد وأهميـة تتظيم المروروالآثار المترتبو على ذلك . - - عبور الطريق من المكان المُخصص لعبور المشاة. - - التأكد من أن الطريق خالى من السيارات القادمة. - - الالنزام بإثتارات المرور الضوئية فى الطريق ومعرفة مدلول كل إثنارة. - - الإشارة الحمراء لقائد السيارة تعنى أن يتوقف (السيارات متوقفة). - الإثـارة الصـفراء تعنـى اسـتعد للمُشــاة والسـيارات ( السـيارات فى وضـع (الانتظار ).

- - الإثـارة الخضـراء تعنى السبيارة تسـبر وأنت تقف فى مكانك ( السـيارات تثحرك) - معرفة فائدة شُرطى المرور ، فى تتظيم الثنارع للسيارات والمُشناة. 


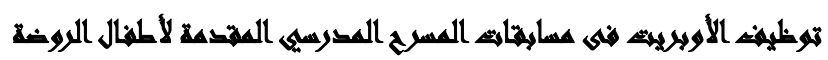

"عراسما تشليلهية"

- تدريب الأطفال على نظام السير فى الطريق.

بيدأ بأغنية استهلالية (الكورال):

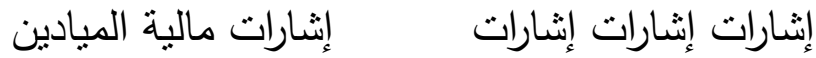

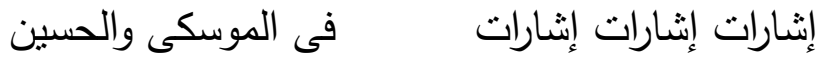

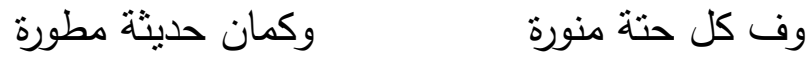

$$
\begin{aligned}
& \text { هنشوفهم فى الميادين }
\end{aligned}
$$

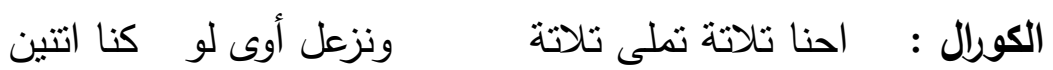

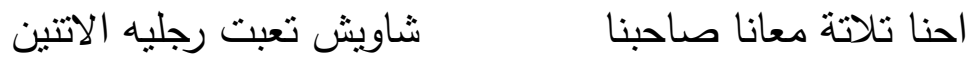

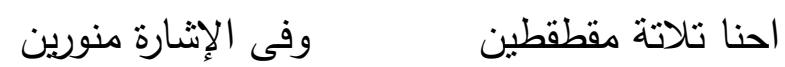

أحمر أصفر أخضر الله علينا كلنا الله علينا كلنا

ثم تبدأ كل إثارة فى عرض وتوضيح وظيفتها :

دمى خفيف ومدورة

عمرى ما يوم قلت أنا

حلوة ومين أدى أنا

بتستعدوا يادى الهنا

نورى يسعد قلبكم

بتعدوا ولا يهمكم

أنا اللى فى إيديا الزمام

ألاقى كله فى التمام

مين غيرك انت رافع راسنا
الإثارة الحمرا : أنا الإشارة الأحمرة

ومحافظة دايماً ع النظام

الإثنارة الصفرا : الوسطانية هو أنا

لما أنور فى الميدان

الإشارة الخضرا : أنا الأمان ليكوا كلكم

صغيرين وكمان كبار

(ويدخل الشاويش عوضين)
أفتح كدة كدة أو كدة

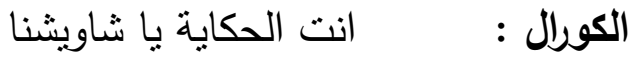




\section{"عراسمة تطليلية"}

$$
\begin{aligned}
& \text { وانت اللى مدينا الأمان } \\
& \text { الكل نايم فى أمان } \\
& \text { عوضين الهمام } \\
& \text { تحية منا كلنا لشاويشنا } \\
& \text { واحنا بنضربله سلام } \\
& \text { بيضحى عمره من أجلنا } \\
& \text { منتكرين ليكوا كلكم }
\end{aligned}
$$

لاحظت الباحثة أن صياغة الأوبريت باللغة العامية تم بحرفية وسهولة نظراً

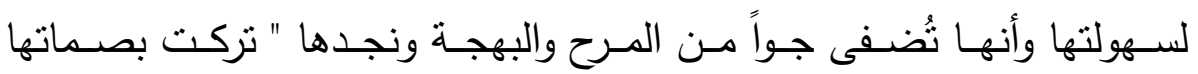
الواضـحة، فهى إلى جانب وظيفتها المعرفيـة فى بلـورة الشخصيات، وتحديد

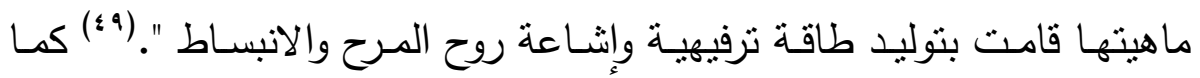
لاحظت التتوع فى الأغانى بين الفردية والمتمنلة فى "الإشارات كل واحدة على حدة" والجماعيـة والمتمنلـة فـى "كورال الأطفـال" ، والموسيقى الحيـة المُؤلفـة،

$$
\text { rالاستعراضات الفردية والجماعية. }
$$

الفكرة: الأوبريت يتتاول أسماء الحروف الهجائية العربية من الألف إلى الياء

$$
\text { (ثمانية وعشرون حرفاً). }
$$

نــوع المســابقة : مسـرحة منـاهج، مدرسـة سـليم زهنى الخاصـة، إدارة شـبين

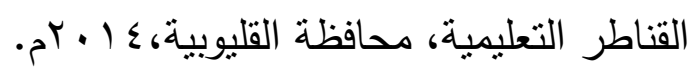
تأليف وإعداد واستعراضات وموسيقى : أ/عاطف عطا مصطفى. الهدف : هو تزويد وتعليم أبناء وتلاميذ مرحلة رياض الأطفال ما يلى:

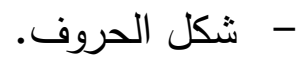
- - - اتقان كتابة الحروف. 


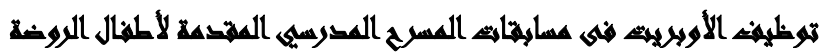

\section{"عراسما تحليلية"}

- أسماء الحروف الهجائية العربية من الألف إلى الباء وفائدتها والتى بدونها

$$
\text { لا نعرف الكتابة ولا القراءة . }
$$

المعلمة: أنـا مس تقى مدرسة الفصل هعرفكم على تلميذاتى وإزاى هما شطار ومنظمين فى درس الحروف الأبجديـة يـلا يـا شطار ادخلوا بنظام مـع الأستاذ عاطف على الموسيقى التلاميذ: أ ب ت ث ج ح خ د ذ ر ز س ش ص ض ط ظ ع غ ف ق ك ل

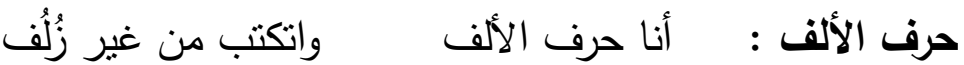
فوق راسى همزة وأحب أقف على السطر ثابت

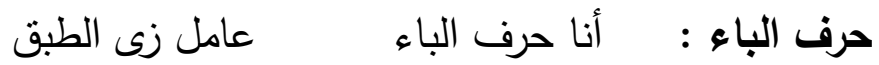
بس من غير غطا وتحتى نقطة صغيرة وليا أخت اسمها تاء عطولها نقطتين صغيرين حطولها ثلاثة حلوين مقطقطين وأخت اسمها ثاء

$$
\text { حرف الجيم : أنا حرف الجيم } \quad \text { و بابدأ بمستقيم }
$$

بنحب بعضنا ونخاف على بعضنا

محتاجة حتة زقة

أخدك وأميل

ثلاثة فى العيلة

فى كلمة شيرين

$$
\text { وحجمه زى حجمى }
$$$$
\text { حرف الراء : أنا الراء كلى رقة }
$$
حرف السين : أنا حرف السين

$$
\text { وأسنانى جميلة }
$$

وأختى اسمها شين

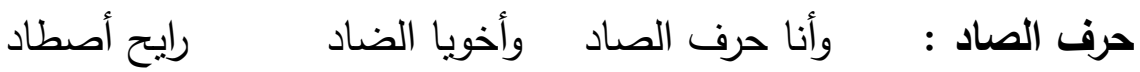




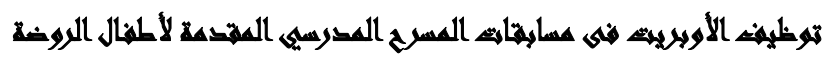

\section{"عراسمة تحليلية"}

$$
\begin{aligned}
& \text { حرف الطاء : أنا حرف الطأطأطأطء وأختى الظأظأظأظء }
\end{aligned}
$$

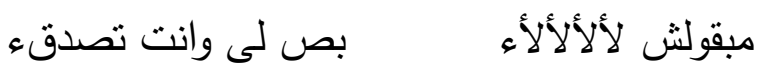

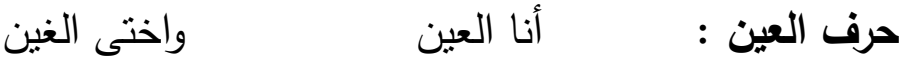

بشوف كل الحلوين والحاجب بتاعى طويل ولية كرش عظيم

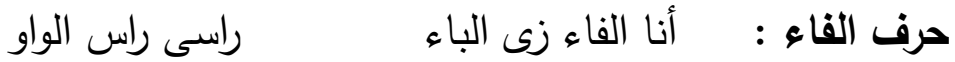

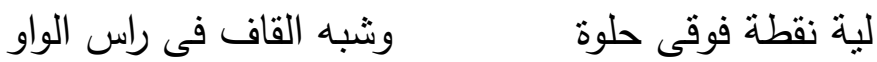

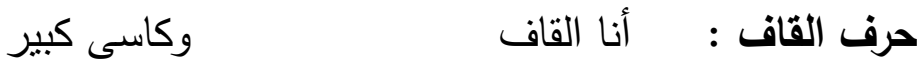

والثطرين عارفين فاهمين فوقى نقطة ونقطة يبقوا اتتين حلوين حلوين

$$
\text { حرف الكاف : أنا الكاف ياسلام علية }
$$

\section{دمه خفيف دمه خفيف}

حرف اللام : أنا اللام ... تقول يا سلام..على الانسجام

$$
\text { ولية زُلُف ... شبه الألف ولية كاسة .... زى القاف }
$$

حرف الميم : أنا الميم أثكالى كتير تلاقيها فى محمد أو محمود أو فى سمير حرف النون : أنا النون من غير سنون ولية كاسة وفيها نقطة وشبه القاف من غير نقطة

حرف الهاء : أنا الهاء، وزى الدال وحط معها حرف الفاء لما تكون فى وسط الكلمة

$$
\text { حرف الواو : أنا الواو من جزئين }
$$

الجزء الأول مثل الفاء والجزء الثانى منل الراء

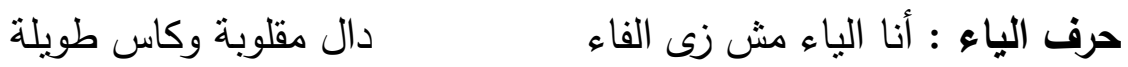




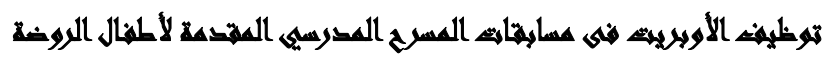

"عراسما تشليلهي"

$$
\text { وفى النهاية أغنية الفينال التلاميذ يرددون ائماً العيلة بياء البطة أو ياء الوزة }
$$

التلاميذ: أ ب ت ث ج ح خ د ذ ر ز س ش ص ض ط ظ ع غ ف ق ك ل

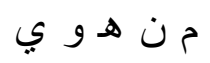

فهى أغنية بسيطة وسـهة، حيث يمكن للطفل أن يُدندن بها ، فتؤثر فى

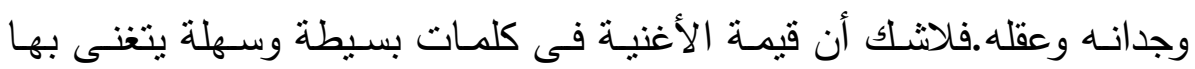
الطفل ويتعايش معها بأسلوب شيق وسلس يسـل حفظه وترديده.إذ لاحظت الباحثة فى الأوبريت الدمج الواضـح بين اللغة العربية العامية البسيطة وكذلك اللغة العربية الفصحى المبسطة، والتى يشوبها التعقيد والاسترسال الغير مُلائم للأطفـال في تلك المرحلـة العمريـة واسـتخدام تراكيب ومعـانى غيـر مفهومـة يصعب عليه فههها بـل وتكرارها فى أكثر من موضـع مثنل ( زُلُفْ- كثيدةكاسـة)، وتتـوع الأغـانى الفرديـة والجماعيـة ، وكـذا الاستعراضـات الفرديـة والجماعية، والموسيقى الحية المُؤلفة.

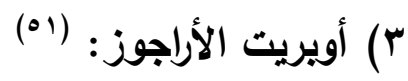
الفكرة: الأوبريت يتتاول تعديل بعض السلوكيات الخاطئة من خلال المواقف، وذلك من خلال تقديم بعض المضامين التربوية التى تتلاءم مع طبيعة المرحلة. نوع المسابقة: فنون مسرحية، محافظة القليوبية، ـا ـ ـ بم. تدريب وتصميم الاستعراضات والألحان : أ/ محمد إسماعيل. الهرف: هو تزويد وتعليم تلاميذ مرحلة رياض الأطفال ما يلى: - أهمية النظام فى حياتتا وضرورة المحافظة عليه. - - المحافظة على ميعاد الروضة. 


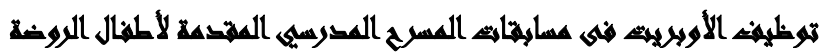

\section{"عراسمة تحليلية"}

- - - ضرورة مشاركة الزملاء فى المحافظة على حجرة الروضة منظمة. - تجنب العادات السيئة كالكسل والإهمال. - تتظيم الوقت يساعد على أداء الواجبات بسرعة.

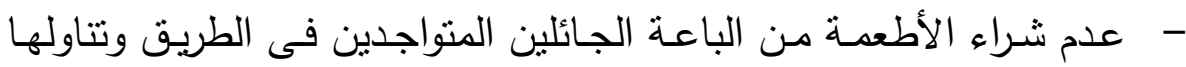
نظراً لأضرارها الكثيرة ولأنها رديئة وجلبها لكثير من الأمراض. - إلقـاء الضـوء على السـلوكيات الإيجابيـة المرغوبـة وضـرورة الاقتـداء بهـا، والسلوكيات السلبية غير المرغوب فيها وتجنبها. وذلك من خلال الأراجوز ومجموعة الأطفال التى أقام المؤلف عليها بناء الأوبريت فى إطار من الحكاية الجميلة الغنائية ومحاولة اضفاء جواً من المرح ليُّلف به العمل بلغة سهلة وبسيطة مناسبة للمرحلة العمرية، لأن إدراك الطفل لم يبلنغ النضـج الكافى لمتابعة حوار، بينما يمكنه أن يرى مسرح عرائس يدور فى شكل جذاب ،يعتمد على الحركة ويُسهم فى ترسيخ بعض القيم الأخلاقية والاجتماعيـة والدينيـة فى نفوس الأطفال الصـار و العمل على تتشئة الطفل وخلق ثقافة عامة من خلال التفاعل مع مسرح العرائس المتمثل فى الأراجوز فهى شخصية كومبدية مُحببة إلى قلوب الأطفال. طقلة : أراجوز زمان فين أياملك وحشنا زمنك وكلامك وسع وسع وسع وسع

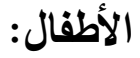
الأراجوز وصل الأراجوز وصل وحشنا زمنك وكلامك وسك وسئ وهن الأراجوز: أنا جيث أنا جيت هحكيلكوا حكاية أحلى دن اللوز أنا جيت ياولاد علثان أنكلم ويا بخت من عاش واتعلم 


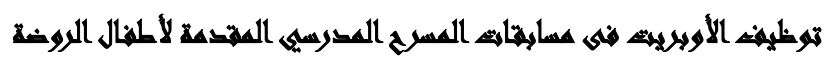

\section{"عراسمة تطليلية"}

الأراجوز : ولد كسول دايماً سهران يصحى للمدرسة كسـان يمشى فى الثـارع

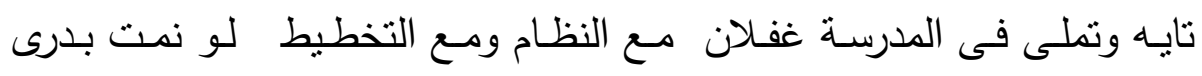
هنصحى نشيط

$$
\text { بقى ده يصح؟ }
$$$$
\text { الأراجوز: - أل }
$$$$
\text { الأطفال: الأنور: }
$$$$
\text { وسع وسع وسع وسع }
$$

الأطفال: - (الأن

الأراجوز وصل الأراجوز وصل راح يحكيلنا حكاية جميلة أحلى وسي

من العسل الأراجوز: من غير فطار مشى واتساهل وراح على بائع جاهل أكل حاجات تعبت بطنه واللى يذقها بستاهل أكل الفطار إما فى بيتتا ياإما نخده فى شنطنتا

$$
\text { الألأطفال: الأطفال: }
$$

الأراجوز وصل الأراجوز وصل راح يحكيلنا حكاية جميلة أحلى من

العسل

الأراجـوز: تملى مشـغول بالألعـاب بعديها مـن مدرسـته غيـاب فى الامتحـان معرفش جواب أصل الثاطر قبل ما يلعب يكتب واجبه وبعديها يلعب

$$
\begin{aligned}
& \text { الأراجوز: بقى ده يصح? ينفع كدة؟ }
\end{aligned}
$$

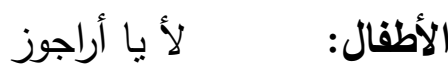

$$
\begin{aligned}
& \text { وسع وسع وسع وسع }
\end{aligned}
$$

الأراجوز وصل الأراجوز وصل راح يحكيلنا حكاية جميلة أحلى من العسل وسع وسع ولاعل 


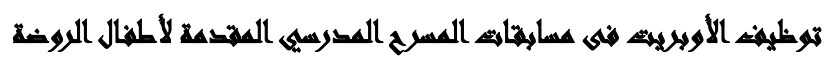

"عراسما تطليلية"

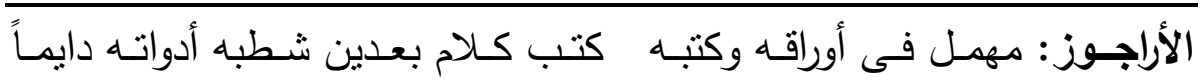
يهملها كل شوية تضبع من جنبه واللى يحافظ على أدواته يفضل ناجح كل حياته

الأراجوز: بقى ده يصح؟ ينفع كدة؟

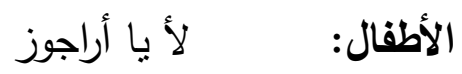

الأطفال: إحنا من الدرس اتعلمنا إحكيلنا يا أراجوز إحكيلنا الأراجوز: خلاص خلصت جكايات النهاردة ؛ ) أويريث الفراشات: (ro)

الفكرة: تتمية بعض السلوكيات الإيجابية فى نفوس التلاميذ . نوع المسابقة: أعياد طفولة، مدرسة سليم زهنى الخاصسة، إدارة بنها التعليمية،

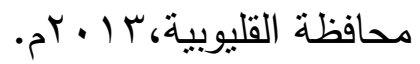
الهـف: هو توعيـة وتثقيف التلاميذ ببعض المعلومـات المناسبة لمـرحلتهم

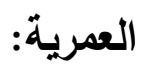

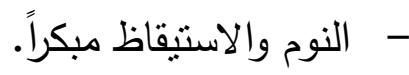

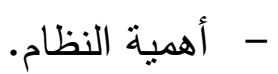
- - الوضوء والصلاة. - الاهتمام بتتظيم الطفل لملابسه وحجرته. - - المحافظة على ميعاد الروضة والجلوس معتدلاً فى الفصل.

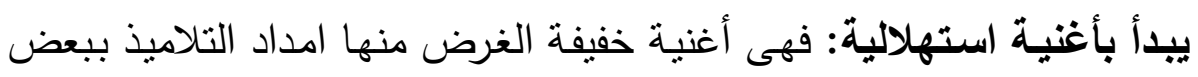
المعلومات الهامة إيماناً بأهمية الأغنية ودورها فى أدب الأطفال" فالأغنية بوجه اعهيه عام لها تأثير كبير على الطفل، فهى تعمل على تتمية المعلومات وتتمية العقل 


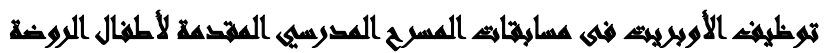

\section{"عرامسا تطليلهي"}

أو يمكن القول أن كل مـا أريد أن أعلمهـ للطفل يمكن أن أعلمهـ عن طريق

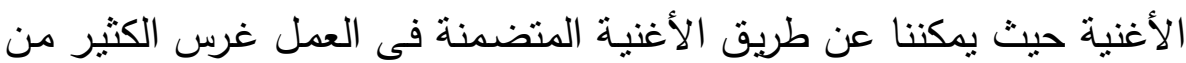

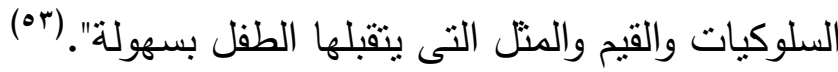

الكورال : احنا الفراثنات الطيارة بنطير ونطير أحلى مافى الدنيا زى ليطى العصافير بنغنى كمان كوكو ونقول ألحان تتجيكوا

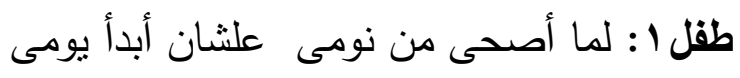

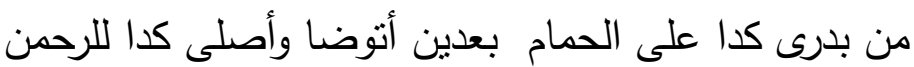
علثان أحسن صورتى دايماً أنظم أوضتى لبنى

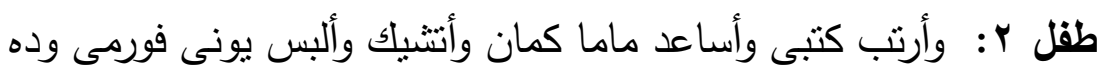

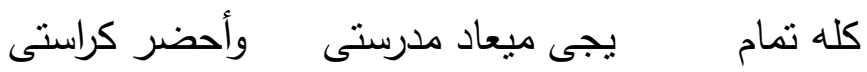

وأروح فى طابورى وأقوم بنظام وأحيى علمنا واضرب لله تعظيم سلام

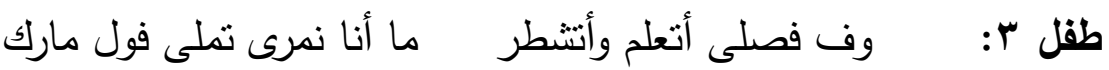

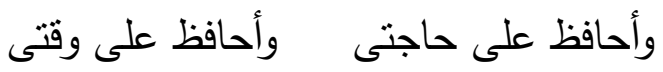

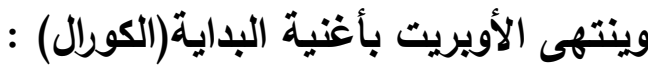

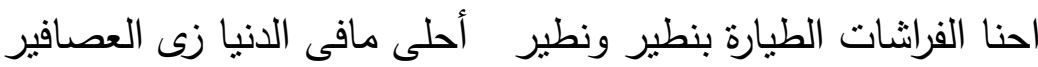
بنغنى كمان كوكو ونقول ألحان تشجيكوا

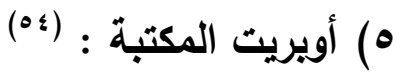
الفكرة: نشر الوعي حول فائدة المكتبة. نوع المسابقة: أعياد طفولة، مدرسة سليم زهنى الخاصة، إدارة بنها التعليمية،

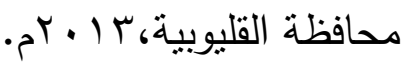




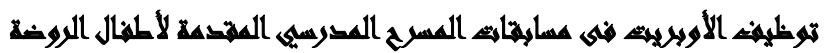

\section{"عراسما تحليلهية}

الهـدف: هو التوعيـة والتثقيف العـام للتلاميذ ببعض المعلومـات عن المكتبـة وأهميتها كتتظيم القراءة لديهج، ونشر الوعي والإمداد بالمعلومات فى التاريخ والعلوم والمعارف، فالمكتبة هي نور وكنزالمعرفة ، إضافة إلى تعليم المستقيدين القراءة والكتابة والتى تتاسب مختلف الأعمار . الكورال : هس هس هس هس ع المكتبة هنطل نبص هس هس هس هس ع المكتبة هنطل نبص نحكى حكاية وقصة جميلة تعرف فيها معانى جميلة كله هيسمع ساكت هس هس هس هس هس ع المكنبة هنطل نبص مئس (استهلالية غنائية يتم من خلالها عرض الرسالة التى يتتاولها الأوبريت فمن مضمون كلماتها تتضح الفكرة)

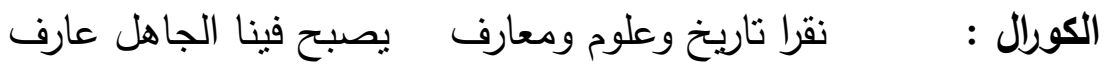
نعرف فكرة ونزرع شجرة ويبقى العلم لسان وشفايف هس هس هس هس عالمكتبة هنطل نبص ع المكتبة هنطل نبص

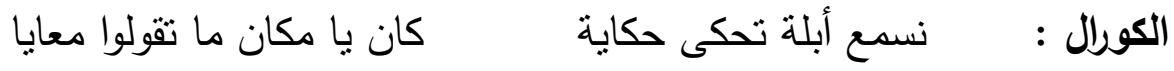
ونقول توتة فى الحدوتة والحدوتة يقولها النص هس هس هس هس ع المكتبة هنطل نبص ع المكنبة هنطل نبص الإطار التحليلى للاراسة التحليلية لعينة الأويريتات المقدمة للمسرح المدرسى (موضوع الاراسة) وعرض لنتائجها (تحليلها وتفسيرها). 


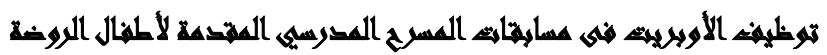

"دراسما تشليلهية"

"تموذج لاستمارة تحليل المضمون حول

توظيف الأويريت فى العروض المسرحية المدرسية المقدمة لأطفال الروضة

"دراسة تحليلية"

فئات استمارة تحليل المضمون

تنقسم الفئات التى تتضمنها استمارة تحليل المضمون إلى فئتين رئيسيتين:- فئة المضمون ( ماذا قيل؟)

- فئة الثكل (كيف قيل؟)

وفيما يلى توضيح أبعاد هذه الفئات كما يلى:

أولاًا : فئات الثكل : (كيف قيل؟) وهذه الفئة تنقسم إلى الأبعاد التالية:

البعد الأول : الثكل الأدبى للأويريت :

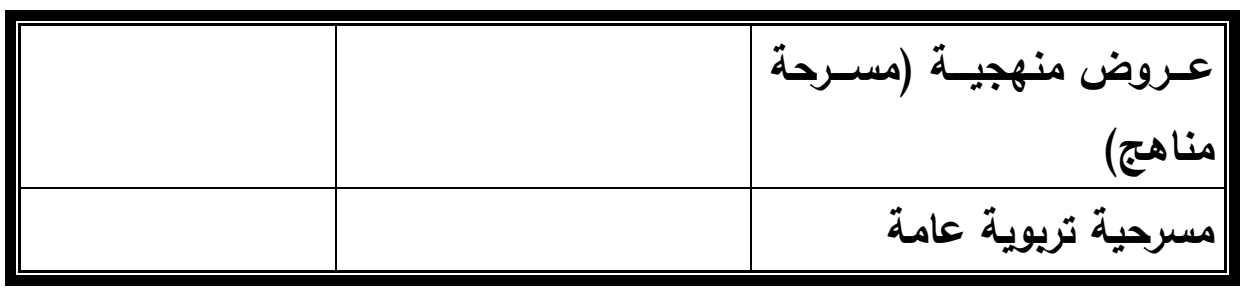

البعد الثانى : نوع المسابقات المقدمة للأويريت:

\begin{tabular}{|r|r|r|}
\hline & & مسابقة العروض المنهجية(مسرحة \\
\hline & & (المناهج) \\
\hline & & مسابقة القنون المسرحية أعياد الطقولة \\
\hline
\end{tabular}




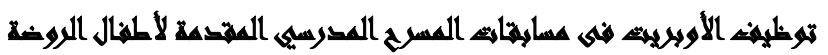

"قراسمة تطليلهية"

البعد الثالث: المرحلة العمرية التى يخاطبها الأويريت:

\begin{tabular}{|c|c|c|}
\hline & & مرحلة الطفولة المبكرة \\
\hline & & مرحلة الطقولة المتأخرة \\
\hline & & لم تحدد \\
\hline
\end{tabular}

البعد الرابع : الإطار الزمانى الذى يجرى فيه الأويريت:

\begin{tabular}{|l|l|r|}
\hline & & قديم \\
\hline & & حديث \\
\hline & & معاصري \\
\hline
\end{tabular}

البعد الخامس: الإطار المكانى الذى يجرى فيه الأويريت:

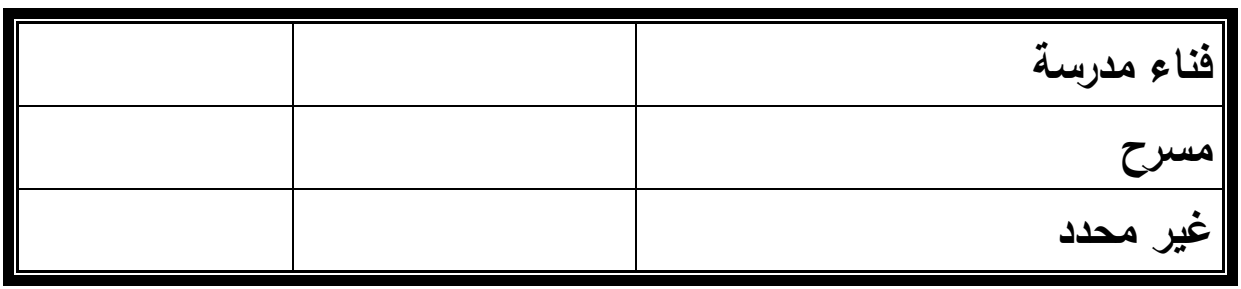

البعد السادس: اللغة المستخدمة فى تقديم الأويريت:

\begin{tabular}{|c|c|c|}
\hline & & اللغة العربية الفصحى المبسطة \\
\hline & & اللهجة العامية \\
\hline & & لغة تجمع بين الفصحى والعامية \\
\hline
\end{tabular}




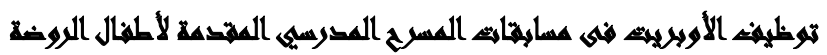

" سراسمة تطليلهية"

ثانياً: فئات المضمون : (ماذا قيل؟) وهذه الفئة تنقسم إلى الأبعاد التالية: البعد الأول: المصدر الأى تستمد منه فكرة الأويريت:

\begin{tabular}{|c|c|c|}
\hline & & أفكار عامة \\
\hline & & المنهج الدراسى \\
\hline & & مصادر أخرى \\
\hline
\end{tabular}

البعد الثانى: المجتمع الذى يتناوله الأويريت: (المجتمع المريى المصرى عموماً

البعد الثالث: نوع المطومات التى ظهرت فى مضمون الأوبريت:

\begin{tabular}{|c|c|c|}
\hline & & المعلومات العلمية \\
\hline & & المعلومات الدينية \\
\hline & & المعلومات القنية \\
\hline & & |معلومات أخرى \\
\hline
\end{tabular}

البعد الرابع: نوعية الثخصيات التى ظهرت فى الأويريت:

\begin{tabular}{|c|c|c|}
\hline & & أطفال \\
\hline & & كبار \\
\hline & & شخصيات أخرى \\
\hline
\end{tabular}




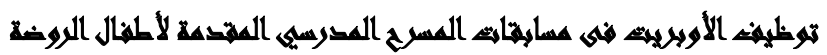

"قراسمة تطليلهية"

البعد الخامس: نوعية الأغنيات التى تناولها الأوبريت:

\begin{tabular}{|r|r|r|}
\hline & (solo) \\
\hline & & (أغانى فردية جماعية \\
\hline & & (أغانى فردية وجماعية(مشتركة) \\
\hline
\end{tabular}

البعد السادس: أسلوب تقديم الموسيقى فى الأويريت:

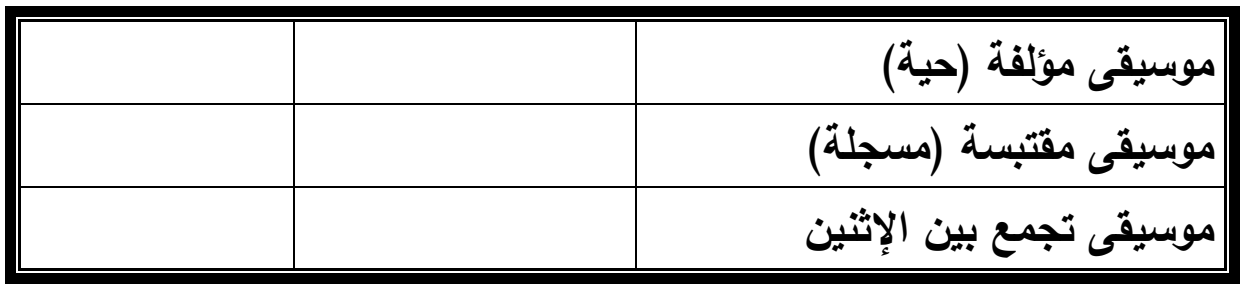

البعد السابع: أسلوب تقديم الاستعراضات فى الأويريت:

\begin{tabular}{|r|r|r|}
\hline & & (استعراضات فردية \\
\hline & & (استعراضات جماعية \\
\hline & & (استعراضات تجمع بين الإثنين \\
\hline
\end{tabular}

البعد الثامن: التهاية التى اختتم بها الأويريت:

\begin{tabular}{|l|r|r|}
\hline & & نهاية منطقية \\
\hline & & نهاية غير منطقية \\
\hline
\end{tabular}




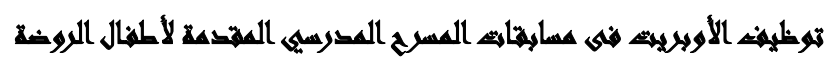

"عراسما تطليلية"

\section{تتائج الدراسة التحليلية وتفسيرها}

يتتـاول هذا الجانـب الدراسـة التحليليـة للأوبريتـات المقدمـة فـى مسـابقات

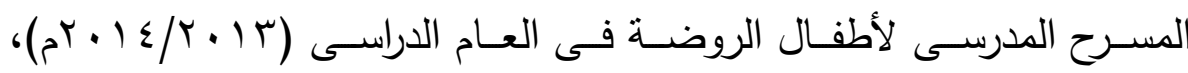
وضمت هذه العينـة إجمـالى خمسـة أوبريتات هـى عينـة الدراسـة المقدمـة فى لـى مسابقات أعياد الطفولة ومسرحة المناهج والفنون المسرحية ،وفيما يلى عرض هلئل لأهم نتائج الدراسـة التحليليـة التحى أُجريـت على تلك العينـة المقدمـة لأطفـال الروضــة فـى مسـابقات المسـرح المدرسـي. ،وذلـلك للإجابـة عـن تسـاؤلات الدراسة،والتعليق على النتائج ومناقثتها ومقارنتها بدراسات وأبحاث أُجريت فى

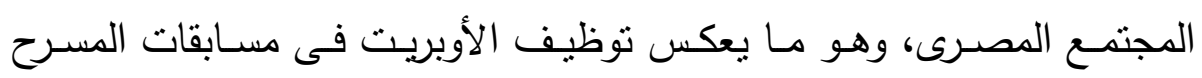

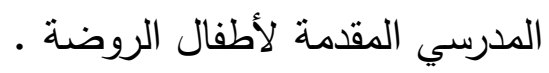

وقد أسفر هذا التحليل بعد عملية الجدولة والتصنيف عن بيانات كمية دعمت الثقة فى النتائج وموضوعيتها،كما ساعدت على تحقيق أهداف الدراسـة والإجابة عن تساؤلاتها ـ 


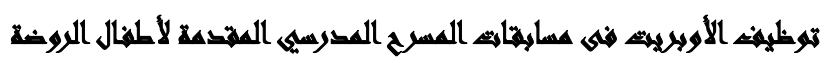

"عراسمة تحليلية"

$$
\begin{aligned}
& \text { أولاًا : فئات الشكل: } \\
& \text { (1) الشكل الأدبى للأويريت }
\end{aligned}
$$

\begin{tabular}{|c|c|c|c|c|c|c|}
\hline \multicolumn{6}{|c|}{ الشكل الأدبى للأويريت } & \multirow{3}{*}{$\hat{\imath}$} \\
\hline \multicolumn{2}{|c|}{ مج ك } & \multicolumn{2}{|c|}{ مسرحية تريوية عامة } & \multicolumn{2}{|c|}{ عروض منهجية } & \\
\hline$\%$ & ك5 & $\%$ & ك & $\%$ & ك & \\
\hline$\% r$. & 1 & - & - & $\%$ & 1 & 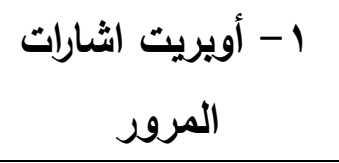 \\
\hline$\% r$. & 1 & - & - & $\% 0$. & 1 & r - أويريت الحروف \\
\hline$\%$ r. & 1 & 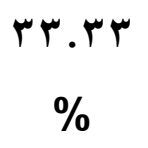 & 1 & - & - & r- أويريث الأراجوز \\
\hline$\% r$. & 1 & $\begin{array}{c}\text { M } \mu \\
\%\end{array}$ & 1 & - & - & ع - أويريث الفراشات \\
\hline$\% r$. & 1 & $\begin{array}{c}\text { ץ }{ }^{\mu} \\
\%\end{array}$ & 1 & - & - & ه - أويريت المكتبة \\
\hline$\% 1 \ldots$ & 0 & $\% 7$. & r & $\% \varepsilon$. & $r$ & مـج ك \\
\hline
\end{tabular}

جدول (1)

يتضع من خلال تحليل بيانات الجدول رقم (1) الآتى:

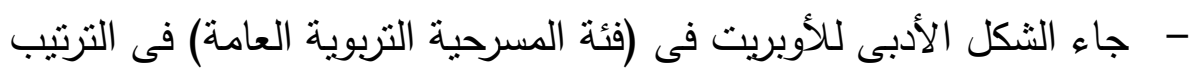




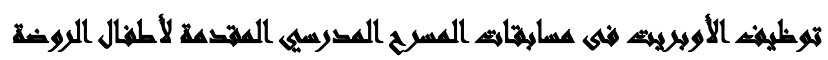

"عراسما تشليلهية"

الأول بنسبة ( ، ؟\%) ، يليها فى الترتيب الثانى (فئة العروض المنهجيـة "مسرحة المناهج") بنسبة ( • ع\%).

- مانتهت نتائج البحث إلى أنه بالنسبة (لفئهة العروض المنهجية ) "مسرحة المنـاهج" جـاءت فى أوبريت إثـارات المرور والحروف تنكلم فى الترتيب

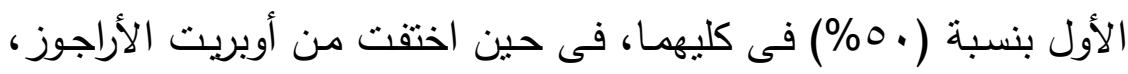

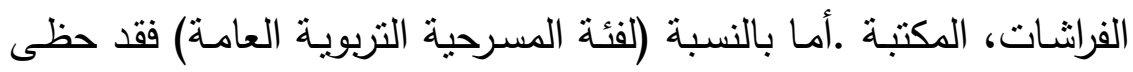
أوبريت الأراجوز والفراشات والمكتبة على نسبة واحدة هى (سب.بr\%) فى حين اختقت من أوبربت إثنارات المرور والحروف نتكلم. (Y) نوع المسابقات المقدمة للأويريت

جدول (ז)

\begin{tabular}{|c|c|c|c|c|c|c|c|c|}
\hline \multicolumn{8}{|c|}{ نوع المسابقات المقدمة للأويريت } & \multirow{5}{*}{$r$} \\
\hline \multirow{3}{*}{\multicolumn{2}{|c|}{ مج ك }} & \multirow{3}{*}{\multicolumn{2}{|c|}{ أعيابقة }} & \multirow{3}{*}{\multicolumn{2}{|c|}{ المسابقة }} & \multirow{3}{*}{\multicolumn{2}{|c|}{ العسابقة }} & \\
\hline & & & & & & & & \\
\hline & & & & & & & & \\
\hline$\%$ & ك5 & $\%$ & ك5 & $\%$ & ك & $\%$ & 5 & \\
\hline$\%$ \%. & 1 & - & - & - & - & $\% 0$. & 1 & المرور \\
\hline \%r. & 1 & - & - & - & - & $\% 0$. & 1 & r - أويريت الحروف تتكلم \\
\hline$\% r$. & 1 & - & - & $\begin{array}{c}1 \ldots \\
\%\end{array}$ & 1 & - & - & r- أويريت الأراجوز \\
\hline
\end{tabular}




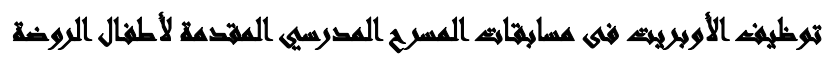

"عراسم تشليلية"

\begin{tabular}{|c|c|c|c|c|c|c|c|c|}
\hline \%r. & 1 & $\begin{array}{l}0 . \\
\%\end{array}$ & 1 & - & - & - & - & ع - أويريت الفراشات \\
\hline$\%$ r. & 1 & $\begin{array}{l}0 . \\
\%\end{array}$ & 1 & - & - & - & - & هـ أويريت المكتبة \\
\hline $\begin{array}{c}1 \ldots \\
\%\end{array}$ & 0 & $\begin{array}{l}\varepsilon . \\
\%\end{array}$ & $r$ & $\% r$. & 1 & $\% \varepsilon$. & $r$ & مج ك5 \\
\hline
\end{tabular}

يتضح من خلال تحليل بيانات الجدول رقم (Y) الآتى:

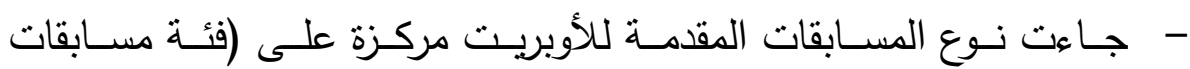

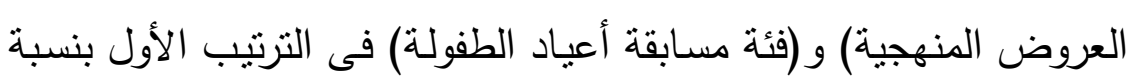

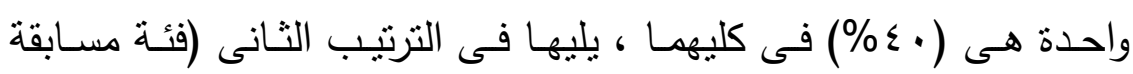

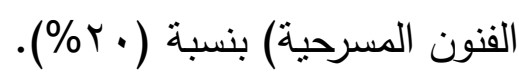

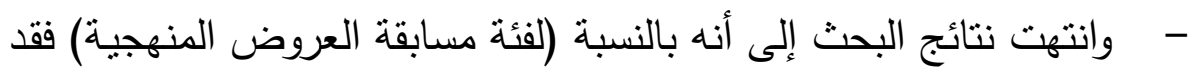

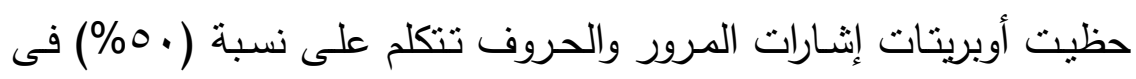

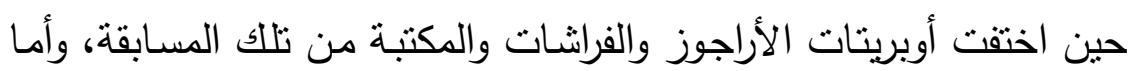

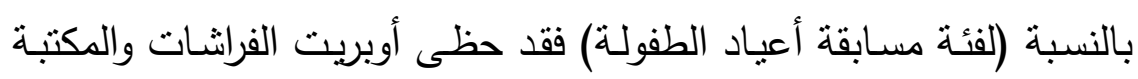
على نفس النسبة وهى ( •\%\% في حين اختقت أوبريتات إثارات المرور والحروف نتكلم والأراجوز من نتلك المسابقة.

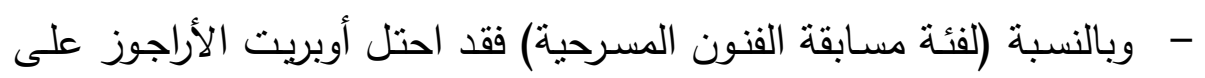

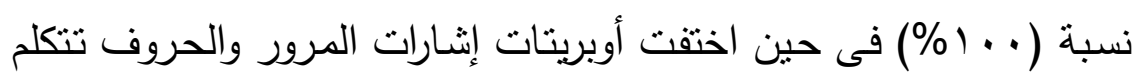
والفراثنات والمكتبة من تلك المسابقة. 


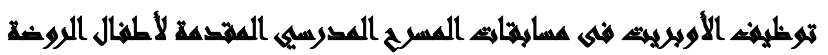

"عراسم تشليلية"

(r) المرحلة العمرية التى يخاطبها الأويريت

جدول (r)

\begin{tabular}{|c|c|c|c|c|c|c|c|c|}
\hline \multicolumn{8}{|c|}{ المرحلة العمرية التى يخاطبها الأويريت } & \multirow{4}{*}{ p } \\
\hline \multirow{2}{*}{\multicolumn{2}{|c|}{ مج ك }} & \multirow{2}{*}{\multicolumn{2}{|c|}{ تجمع بين }} & \multirow{2}{*}{\multicolumn{2}{|c|}{ الطرحلة }} & \multirow{2}{*}{\multicolumn{2}{|c|}{ الطفولة المبكرة }} & \\
\hline & & & & & & & & \\
\hline$\%$ & ك5 & $\%$ & 5 & $\%$ & ك5 & $\%$ & ك5 & \\
\hline$\%$ r. & 1 & - & - & - & - & \%ro & 1 & المرور أويريـــــ اشـــــارت \\
\hline$\%$ r. & 1 & $\begin{array}{l}1 \cdots \\
\%\end{array}$ & 1 & - & - & - & - & ب ب- أويريـــت الحــروف \\
\hline$\%$ r. & 1 & - & - & - & - & $\%$ ro & 1 & r- أويريت الأراجوز \\
\hline$\% r$. & 1 & - & - & - & - & $\%$ ro & 1 & ع - أويريت الفراشات \\
\hline$\%$ r. & 1 & - & - & - & - & \%ro & 1 & 0- أويريت المكتبة \\
\hline $\begin{array}{l}1 \ldots \\
\%\end{array}$ & 0 & $\% r$. & 1 & - & - & $\% \wedge$ & $\varepsilon$ & 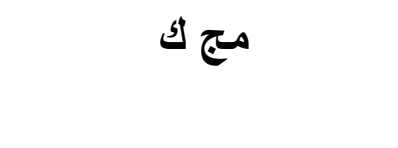 \\
\hline
\end{tabular}

يتضح من خلال تحليل بيانات الجدول رقم (r) الآتى:

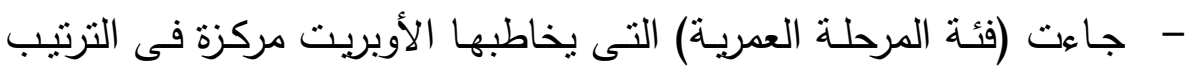

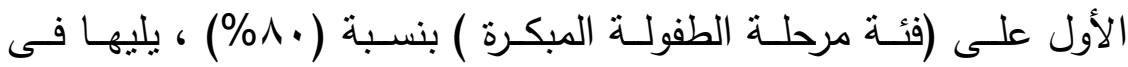

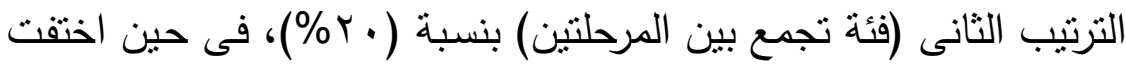




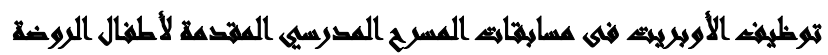

\section{"عراسمة تطليلية"}

(فئة مرحلة الطفولة المتأخرة) التى يخاطبها الأوبريت.

- - وانتهت نتائج البحث إلى أنه بالنسبة لمرحلة الطفولة المبكرة فقد حظيت أوبريتات إثنارات المرور والأراجوز والفراشـات والمكتبـة على نفس النسبة (\%) في حين اختقى من تلك المرحلة أوبريت الحروف تتكلم ، أمـا بالنسبة لفئة تجمع بين الإثنين (مرحلة الطفولة المبكرة والمتأخرة) فقد حظي أوبريـت الحروف تنكلم على نسبة ( . . (\%) واختفت أوبريتات إثـارات المرور والأراجوز والفراشات والمكتبة من تلك المرحلة. - اختق (فئة مرحلة الطفولة المتأخرة) فى جميع الأوبريتات. (ع ) الإطار الزمانى الأى يجرى فيه الأويريت

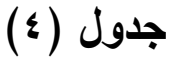

\begin{tabular}{|c|c|c|c|c|c|c|c|c|}
\hline \multicolumn{8}{|c|}{ الإطار الزمانى الأى يجرى فيه الأويريت } & \multirow[b]{3}{*}{ p } \\
\hline \multicolumn{2}{|c|}{ مج ك } & \multicolumn{2}{|c|}{ معاصر } & \multicolumn{2}{|c|}{ حديث } & \multicolumn{2}{|c|}{ 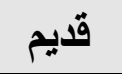 } & \\
\hline$\%$ & ك & $\%$ & 5) & $\%$ & ك5 & $\%$ & ك5 & \\
\hline$\%$ \%. & 1 & $\% r$. & 1 & - & - & - & - & 1 - أويريث اشارات المرور \\
\hline$\%$ \%. & 1 & $\% r$. & 1 & - & - & - & - & ץ - أويريث الحروف تتكلم \\
\hline$\%$ \%. & 1 & $\% r$. & 1 & - & - & - & - & ب- أويريت الأراجوز \\
\hline$\%$ \%. & 1 & $\% r$. & 1 & - & - & - & - & ع - أويريت الفراشات \\
\hline$\%$ \%. & 1 & $\% r$. & 1 & - & - & - & - & 0- أويريت المكتبة \\
\hline $\begin{array}{c}1 \ldots \\
\%\end{array}$ & 0 & $\begin{array}{c}1 \ldots \\
\%\end{array}$ & 0 & - & - & - & - & مج ك \\
\hline
\end{tabular}




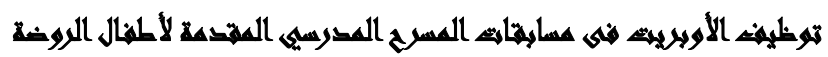

"عراسما تطليلية"

يتضح من خلال تحليل بيانات الجدول رقم (ع ) الآتى:

- - أن (فئهة الـزمن المعاصـر) هـى أنسـب الأزمنـة التى تـدور فيهـا أحداث الأوبريـت حيـث بلغت نسـبتها ( . (\%) مسن إجمالى الأزمنـة، فى حين اختقت (فئات الزمن القديم والحديث) من كل الأوبريتات.

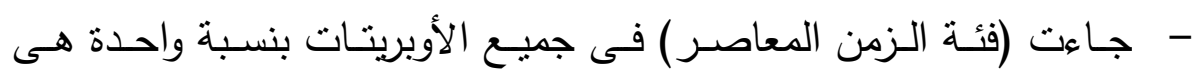
$\cdot(\% r \cdot)$

(0) الإطار المكانى الأى يجرى فيه الأويريت

جدول (0)

الإطار المكانى الأى يجرى فيه الأويريت

\begin{tabular}{|c|c|c|c|c|c|c|c|c|}
\hline \multicolumn{2}{|c|}{ مج ك } & \multicolumn{2}{|c|}{ غير محدد } & \multicolumn{2}{|c|}{ مسرح } & \multicolumn{2}{|c|}{ فناء } & \multirow[t]{2}{*}{ p } \\
\hline$\%$ & ك & $\%$ & ك & $\%$ & ك5 & $\%$ & ك & \\
\hline$\%$ \%. & 1 & - & - & $\%$ \%. & 1 & - & - & المرور - أويريــت اشــارات \\
\hline$\%$ \%. & 1 & - & - & $\%$ \%. & 1 & - & - & ب - أويريـت الحـروف \\
\hline$\% r$. & 1 & - & - & $\%$ \%. & 1 & - & - & r- أويريت الأرجوز \\
\hline$\% r$. & 1 & - & - & $\%$ r. & 1 & - & - & ع - أويريث الفراشات \\
\hline$\% r$ & 1 & - & - & $\% r$. & 1 & - & - & ه - أويريت المكتبة \\
\hline$\% 1 \ldots$ & 0 & - & - & $\% 1 \ldots$ & 0 & - & - & مج ك \\
\hline
\end{tabular}




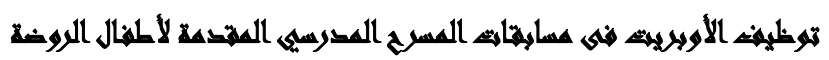

"عراسم تشليليه"

يتضح من خلال تحليل بيانات الجدول رقم (0) الآتى:

- جاءت(فئة المسرح)هى أنسب الأماكن فى الترتيب الأول حيث بلغت

نسبتها ـ . 1\% من إجمالى الأماكن التى تدور فيها أحداث الأوبريت ، بينما

اختقت ( فئة فناء المدرسة)و (فئة غير محدد) فى جميع الأوبريتات.

- وجاءت (فئة المسرح) بنسبة واحدة هى (·r\%) فى جميع الأوبريتات . . -

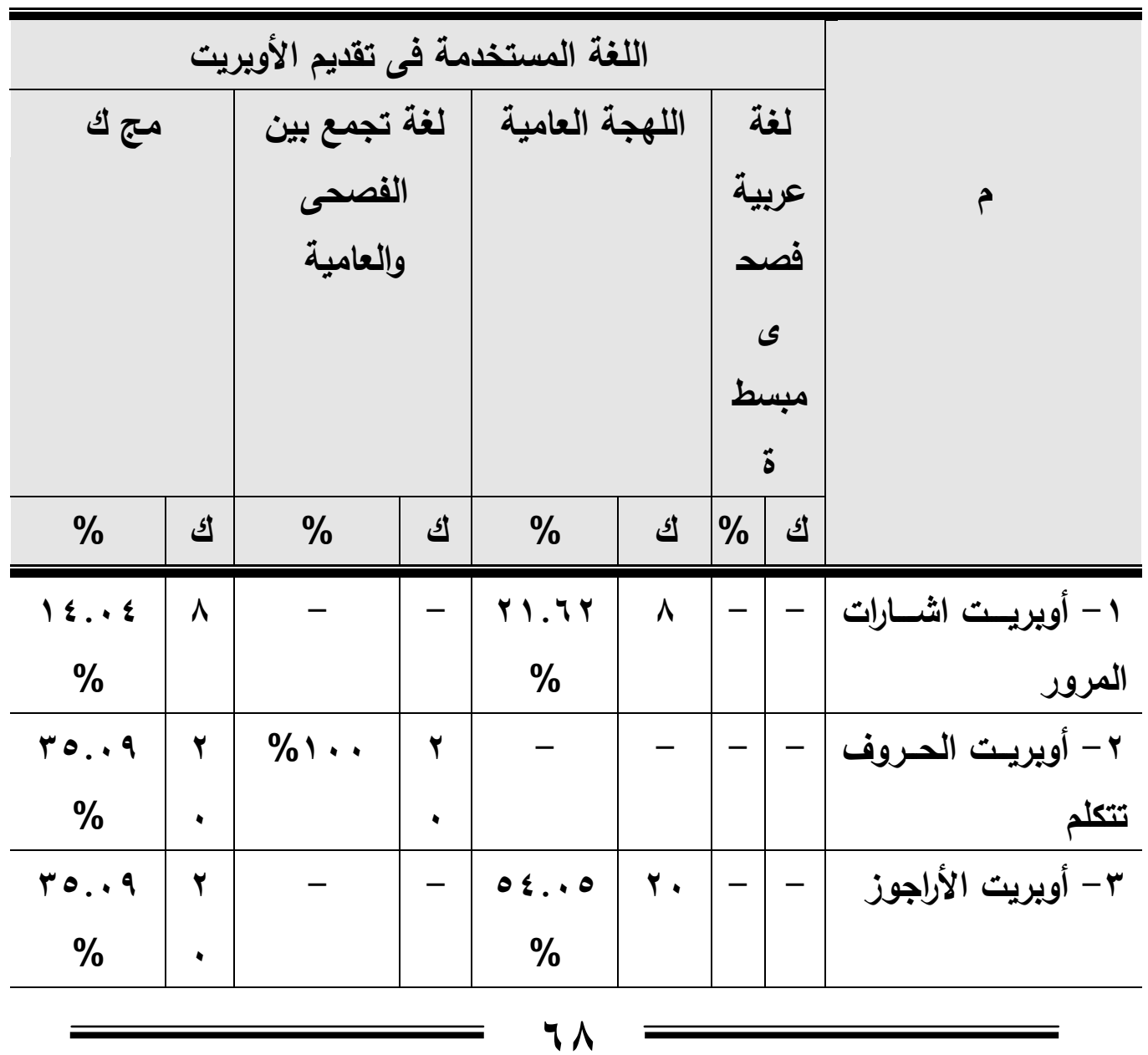




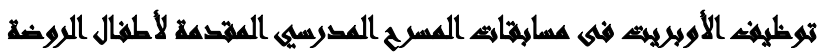

"عرامس تشليلهية"

\begin{tabular}{|c|c|c|c|c|c|c|c|c|}
\hline $\begin{array}{c}1 . .0 r \\
\%\end{array}$ & 7 & - & - & $\begin{array}{c}17 . r r \\
\%\end{array}$ & 7 & - & - & ع - أويريت الفراشات \\
\hline$\% 0 . Y 7$ & $r$ & - & - & $\% \wedge .11$ & $r$ & - & - & ه - أويريت المكتبة \\
\hline$\% 1 \ldots$ & $\begin{array}{l}0 \\
v\end{array}$ & $\begin{array}{c}r 0 . . q \\
\%\end{array}$ & r & $\begin{array}{c}7 \leq .91 \\
\%\end{array}$ & $r v$ & - & - & مج ك5 \\
\hline
\end{tabular}

(7) اللغة المستخدمة فى تقديم الأويريت

يتضح من خلال تحليل بيانات الجدول رقم (7) الآتى:

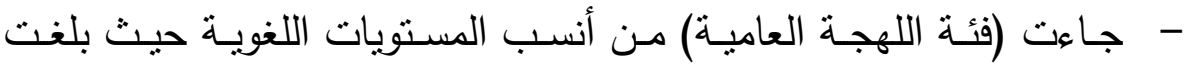

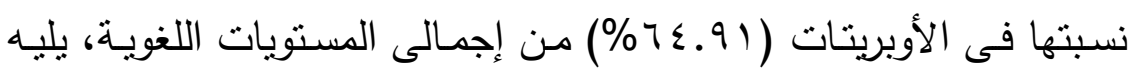

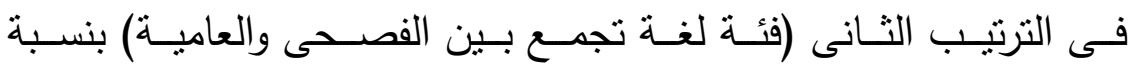
(9 . .0\%\%) من إجمالى المستويات اللغوية ، فى حين اختفت (فئة اللغة العربية الفصحى المبسطة) من جميع الأوبريتات. - وجاءت (فئة اللهجة العامية) فى الترتيب الأول فى أوبربت الأراجوز بنسبة

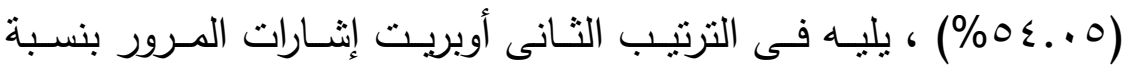

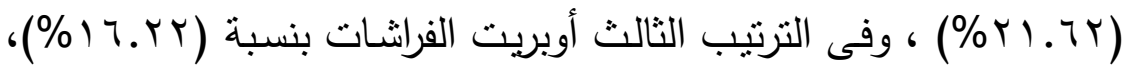
وفى الترتيب الرابع والأخير أوبريت المكتبـة بنسبة (1 (1\%)، في حين اختقت أوبريت الحروف نتكلم من تلك الفئة.

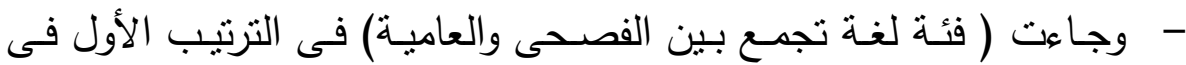
أوبريت الحروف تتكلم بنسبة ( . . (\%) فى اختفى أوبريت إثـارات المرور و الأراجوز و الفراشات و والمكتبة من نلك الفئة. 


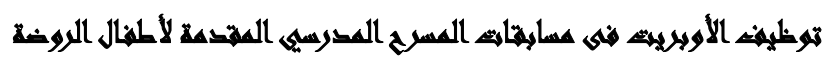

\section{"عراسمة تحليلية"}

- م ولاحظت الباحثة صياغة الأوبريتات عينة البحث بلغة سهلة واضحة، وتم

توظيف اللغة العامية فى جميع الأوبريتات بحرفية وسهولة نظراًً لسهولتها

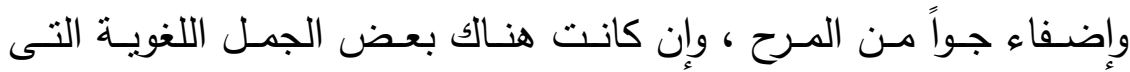

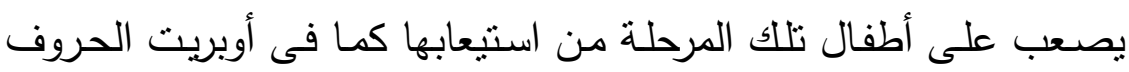

تتكلم.

ثانياً : فئات المضمون:

المصدر الأى تستمد منه فكرة الأويريث (V)

جدول (v)

\begin{tabular}{|c|c|c|c|c|c|c|c|c|}
\hline \multicolumn{8}{|c|}{ المصدر الذى تستمد منه فكرة الأوبريت } & \multirow{3}{*}{$r$} \\
\hline \multicolumn{2}{|c|}{ مج ك } & \multicolumn{2}{|c|}{ مصادر } & \multicolumn{2}{|c|}{ الدراسهج } & \multicolumn{2}{|c|}{ 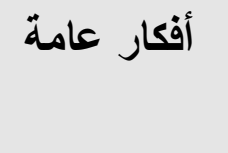 } & \\
\hline$\%$ & 5 & $\%$ & 5 & $\%$ & ك5 & $\%$ & ك5 & \\
\hline \%r. & 1 & - & - & $\begin{array}{l}0 . \\
\%\end{array}$ & 1 & - & - & المرور - أويريــت اثــارات \\
\hline$\% r$. & 1 & - & - & $\begin{array}{l}0 . \\
\%\end{array}$ & 1 & - & - & بت - أويريـت الحـروف \\
\hline$\% r$ & 1 & - & - & - & - & $\begin{array}{c}r . \mu r \\
\%\end{array}$ & 1 & r- أويريت الأراجوز \\
\hline$\% r$. & 1 & - & - & - & - & $\begin{array}{c}\mu r . \mu r \\
\%\end{array}$ & 1 & ع - أويريت الفراشات \\
\hline
\end{tabular}




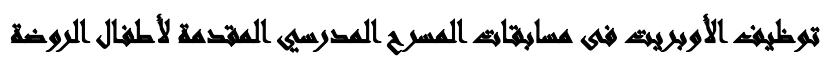

"عراسما تشليلهية"

\begin{tabular}{|c|c|c|c|c|c|c|c|c|}
\hline$\%$ r. & 1 & - & - & - & - & $\begin{array}{c}r \text { r.r } \\
\%\end{array}$ & 1 & ه - أويريت المكتبة \\
\hline $\begin{array}{l}1 \ldots \\
\%\end{array}$ & 0 & - & - & $\begin{array}{l}\varepsilon . \\
\%\end{array}$ & $r$ & $\% 7$. & $\mu$ & مج ك \\
\hline
\end{tabular}

يتضح من خلال تحليل بيانات الجدول رقم (V) الآتى:

- - جـاءت (فئـة أفكـار عامـة) مـن أنسـب المصـادر التى تسـتمد منهـا فكرة

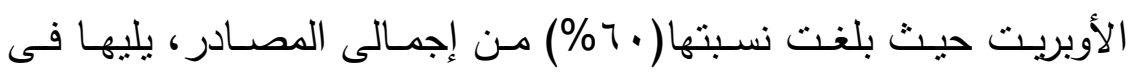

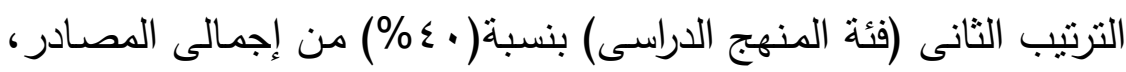
فى حين اختفت (فئة مصادر أخرى) من جميع الأوبريتات.

- - جـاءت (فئسة أفكـار عامـة) فى الترتيب الأول بنسبة واحدة فى أوبريتـات الأراجوز والفراشات والمكتبة هى (r.r.r\%\%) ، بينما اختقت فى أوبربت إثارات المرور والحروف تتكلم.

- وجاءت (فئة المنهج الدراسى) فى الترتيب الأول بنسبة ( •0\%) فى أوبريت إثـارات المرور والحروف تتكلم فى حين اختقت من أوبريتات الأراجوز والفراشـات والمكتبـة، بينمـا اختفـت ( فئـة مصــادر أخـرى) مـن جميـع الأوبريتات. 


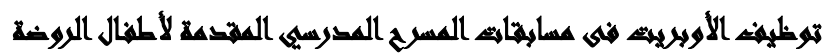

"عراسم تشليليه"

( المجتمع الأى يتناوله الأويريت

جدول (^)

\begin{tabular}{|c|c|c|c|c|c|c|}
\hline \multicolumn{6}{|c|}{ المجتمع الذى يتتاوله الأويريت } & \multirow{3}{*}{ r } \\
\hline \multicolumn{2}{|c|}{ مج ك } & \multicolumn{2}{|c|}{ المجتمع } & \multicolumn{2}{|c|}{ المجتمع } & \\
\hline$\%$ & 5 & $\%$ & 5 & $\%$ & ك & \\
\hline \%r. & 1 & - & - & $\%$ \%. & 1 & 1- أويريت اشارات \\
\hline$\%$ \%. & 1 & - & - & $\%$ r. & 1 & r - أويريت الحروف \\
\hline$\%$ r. & 1 & - & - & $\%$ r. & 1 & ب- أويريت الأراجوز \\
\hline$\%$ \%. & 1 & - & - & $\%$ \%. & 1 & ع - أويريت الفراشات \\
\hline$\% r$. & 1 & - & - & $\% r$. & 1 & ه - أوبريت المكتبة \\
\hline$\% 1 \ldots$ & 0 & - & - & $\% 1 \ldots$ & 0 & مج ك \\
\hline
\end{tabular}

يتضح من خلال تحليل بيانات الجدول رقم (^) الآتى:

- كانت (فئة المجتمع المصـرى) هـى أنسب المجتمعات حيث بلغت حيث بلغت نسبتهم ( . . (\%) من إجمالى أنواع المجتمعات، بينما اختقت (فئة المجتمع العربى) فى جميع الأوبريتات.

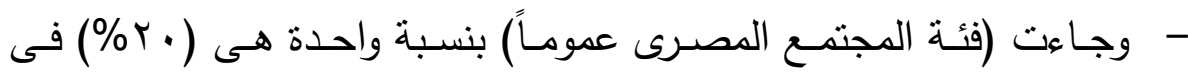




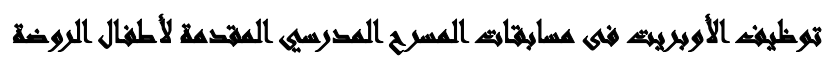

"عراسم تشليليه"

أوبريت إثـارات المرور، والحروف تنكلم، والأراجوز، والفراثنات ،والمكتبة،

بينما اختقت (فئة المجتمع العربى) فى جميع الأوبريتات.

(9) نوع المعلومات التى ظهرت فى مضمون الأويريت

جدول (9)

\begin{tabular}{|c|c|c|c|c|c|c|c|c|}
\hline \multicolumn{8}{|c|}{ نوع المعلومات التى ظهرت فى مضمون الأويريت } & \multirow{3}{*}{ r } \\
\hline \multicolumn{2}{|c|}{ 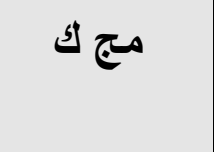 } & \multicolumn{2}{|c|}{ معلومات } & \multicolumn{2}{|c|}{ معلومات } & \multicolumn{2}{|c|}{ معلومات } & \\
\hline$\%$ & ك5 & $\%$ & ك5 & $\%$ & ك & $\%$ & ك & \\
\hline $\begin{array}{l}1 Y .0 \\
\%\end{array}$ & 1 & - & - & - & - & $\%$ Y. & 1 & المرور - أويريــت اثـــارات \\
\hline $\begin{array}{l}\text { IY.o } \\
\%\end{array}$ & 1 & - & - & - & - & $\%$ r. & 1 & r - أويريــث الحـروف \\
\hline $\begin{array}{l}1 Y .0 \\
\%\end{array}$ & 1 & - & - & - & - & $\%$ r. & 1 & r- أويريت الأرجوز \\
\hline $\begin{array}{l}\text { PV.o } \\
\%\end{array}$ & $r$ & $\begin{array}{l}0 . \\
\%\end{array}$ & 1 & $\begin{array}{l}1 \ldots \\
\%\end{array}$ & 1 & \%r. & 1 & ع - أويريت الفراشات \\
\hline \%ro & $r$ & $\begin{array}{l}\circ . \\
\%\end{array}$ & 1 & - & - & $\%$ \%. & 1 & ه - أويريت المكتبة \\
\hline $\begin{array}{l}1 \cdots \\
\%\end{array}$ & $\Lambda$ & $\begin{array}{l}\text { ro } \\
\%\end{array}$ & $r$ & $\begin{array}{l}1 Y .0 \\
\%\end{array}$ & 1 & $\begin{array}{l}9 Y .0 \\
\%\end{array}$ & 0 & مج ل5 \\
\hline
\end{tabular}




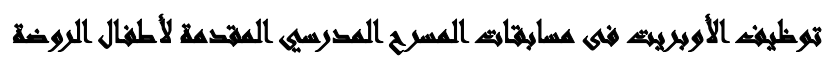

"عراسما تطليلية"

يتضح من خلال تحليل بيانات الجدول رقم (9) الآتى:

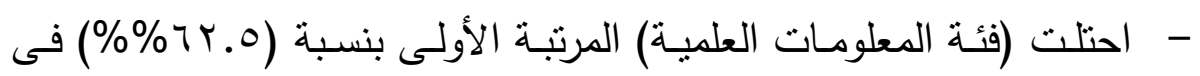
أوبريتات البحث، وجـاءت (فئة المعلومـات الجماليـة) فـى المرتبـة الثانيـة

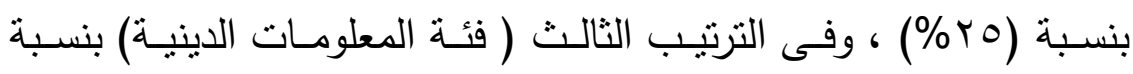
(\%. (\% ) من إجمالى عينة البحث.

- مجاءت (فئة المعلومات العلميـة) بنسبة واحدة هى ( • ب \%) فى مجموعة أوبريتات البحث.

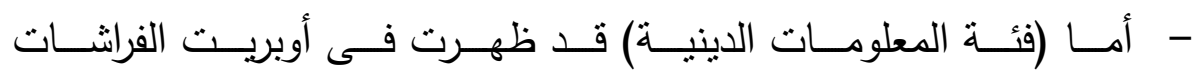

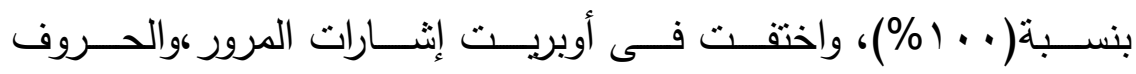
تتكلم ،والأراجوز كوالمكنبة.

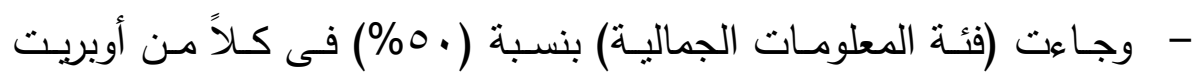
الفراشات ،والمكتبة، فى حين اختقت من أوبريت إثـارات المرور ،والحروف لهن

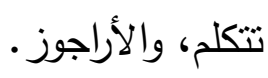




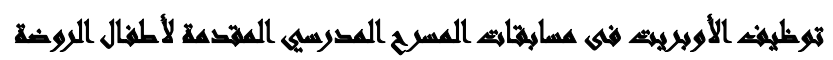

"عراسما تطليلية"

(1. (1) نوعية الشخصيات التى ظهرث فى الأويريت

جدول (· (1)

\begin{tabular}{|c|c|c|c|c|c|c|c|c|}
\hline \multicolumn{8}{|c|}{ نوعية الشخصيات التى ظهرت فى الأويريت } & \multirow{3}{*}{ r } \\
\hline \multicolumn{2}{|c|}{ مج ت } & \multicolumn{2}{|c|}{ شخصيات } & \multicolumn{2}{|l|}{ كبار } & \multicolumn{2}{|c|}{ أطقال } & \\
\hline$\%$ & 5 & $\%$ & ك & $\%$ & ك5 & $\%$ & 5 & \\
\hline $\begin{array}{c}r q .91 \\
\%\end{array}$ & 18 & - & - & $\begin{array}{c}r r . r T \\
\%\end{array}$ & 1 & $\begin{array}{c}\text { YV.I } \\
\%\end{array}$ & $\begin{array}{l}1 \\
7\end{array}$ & المرور أويريـت اشـارات \\
\hline $\begin{array}{c}19 . .0 \\
\%\end{array}$ & Ir & - & - & - & - & $\begin{array}{c}r . . r \varepsilon \\
\%\end{array}$ & $\begin{array}{l}1 \\
r\end{array}$ & r ب - أويريث الحروف \\
\hline \% \%.ro & $\varepsilon$ & $\% 1 \ldots$ & 1 & - & - & $\% 0.1$ & $r$ & r- أويريث الأراجوز \\
\hline $\begin{array}{c}r . .91 \\
\%\end{array}$ & 18 & - & - & $\begin{array}{c}M r . M r \\
\%\end{array}$ & 1 & $\begin{array}{c}r V . I r \\
\%\end{array}$ & $\begin{array}{l}1 \\
7\end{array}$ & ع الفراشـات أوبريــــــــــ \\
\hline $\begin{array}{c}r . .7 r \\
\%\end{array}$ & Ir & - & - & $\begin{array}{c}M r . \mu r \\
\%\end{array}$ & 1 & $\begin{array}{c}r \cdot . r \varepsilon \\
\%\end{array}$ & $\begin{array}{l}1 \\
r\end{array}$ & 0- أويريت المكتبة \\
\hline$\% 1 \ldots$ & $7 r$ & $\% 1.09$ & 1 & $\begin{array}{l}\varepsilon . \vee\urcorner \\
\%\end{array}$ & $\mu$ & $\% q r . V$ & $\begin{array}{l}0 \\
9\end{array}$ & مج ك (5 \\
\hline
\end{tabular}

يتضح من خلال تحليل بيانات الجدول رقم (• (1) الآتى:

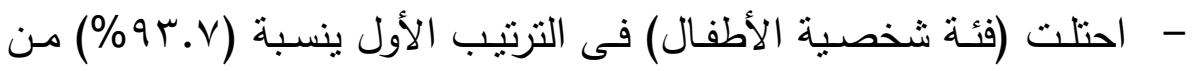

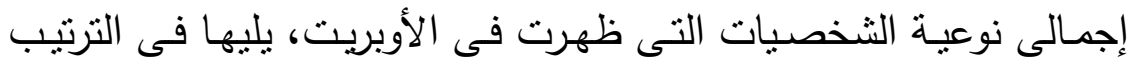




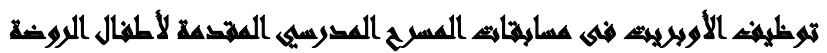

\section{"كراسها تطليلية"}

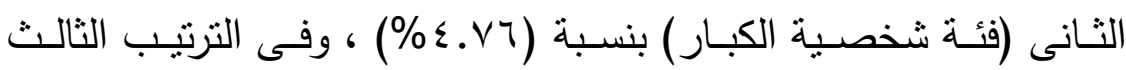
والأخير (فئة شخصيات أخرى) بنسبة (09.09\%) .

- - جاءت (فئة شخصيات الأطفـال) التى ظهرت فى الأوبريت فى الترتيب

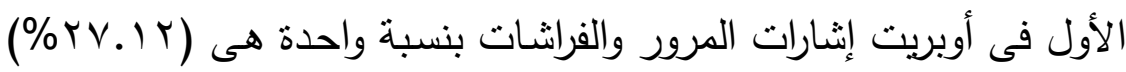
فى كليهما ،وفى الترتيب الثانى أوبريت الحروف تتكلم والمكتبة قد جاءوا

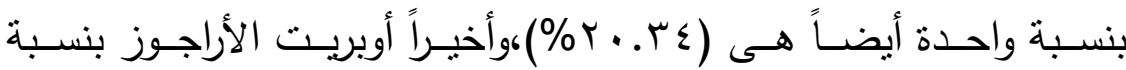

$$
.(\% \bullet . \wedge)
$$

- أمسا (فئة شخصيات الكبار) فقد جاءت بنسبة واحدة فى أوبريت إثـارات

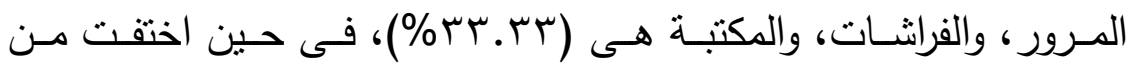
أوبربت الحروف تتكلم، والأراجوز •

- أمـا (فئة شخصيات أخرى) فقد احتل فيها المركز الأول الأراجوز بنسبة

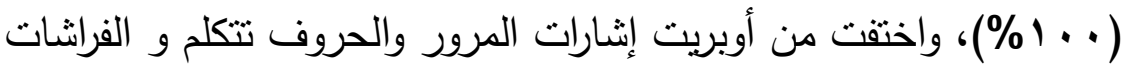

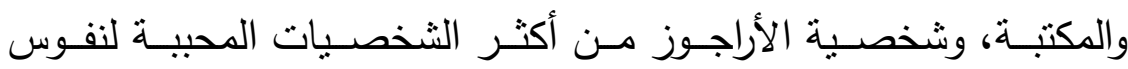

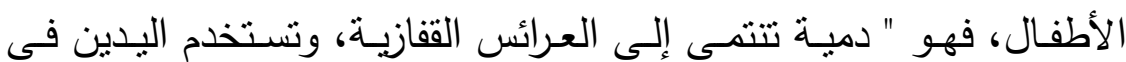
تحريكها بواسـة الأصـابع ولها غطاء للرأس يسـى طرطور ، والأراجـوز يتميز مسـرحه بسـهولة التتقل، وكل الاحتياجـات الفنيـة، فهو يتمتع بخفـة الظل، وطول اللسان، والنقد الساخر لكل من حوله من عيوب." (00) 


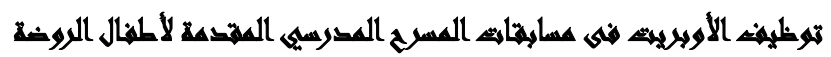

"عراسم تشليليه"

(11) نوعية الأغنيات التى تتاولها الأويريت

جدول (11)

\begin{tabular}{|c|c|c|c|c|c|c|c|c|}
\hline \multicolumn{8}{|c|}{ نوعية الأغنيات التى تناولها الأويريت } & \multirow{3}{*}{ r } \\
\hline \multicolumn{2}{|c|}{ مج ك } & \multicolumn{2}{|c|}{ وزردية } & \multicolumn{2}{|c|}{ جماعانية } & \multicolumn{2}{|c|}{ فرديةة(solo) } & \\
\hline$\%$ & ك5 & $\%$ & 5 & $\%$ & 55 & $\%$ & ك5 & \\
\hline $\begin{array}{c}1 \varepsilon .00 \\
\%\end{array}$ & $\Lambda$ & - & - & $\begin{array}{l}1 \wedge .1 \\
\% \wedge\end{array}$ & $\varepsilon$ & $\begin{array}{l}\text { M.IY } \\
\%\end{array}$ & $\varepsilon$ & المرور - أويريــث اشــارات \\
\hline $\begin{array}{c}\text { wy } \\
\%\end{array}$ & $r$. & - & - & $\begin{array}{l}9 . .9 \\
\%\end{array}$ & $r$ & $\begin{array}{c}0 \leq .00 \\
\%\end{array}$ & 1 & r ب - أويريـت الحـروف \\
\hline $\begin{array}{c}r q . r q \\
\%\end{array}$ & $r \cdot$ & - & - & $\begin{array}{l}\varepsilon \cdot .9 \\
\% 1\end{array}$ & 9 & $\begin{array}{c}r . r r \\
\%\end{array}$ & 1 & r- أويريت الأراجوز \\
\hline$\% \vee . r V$ & $\varepsilon$ & - & - & $\begin{array}{l}1 \wedge .1 \\
\% \wedge\end{array}$ & $\varepsilon$ & - & - & ع - أويريت الفراشات \\
\hline$\% 0 . \leqslant 0$ & $r$ & - & - & $\begin{array}{l}1 T .7 \\
\% \varepsilon\end{array}$ & $r$ & - & - & 0 - أويريت المكتبة \\
\hline$\% 1 \ldots$ & 00 & - & - & $\%$ \&. & $r r$ & $\% 7$. & $r$ & 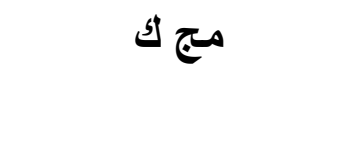 \\
\hline
\end{tabular}




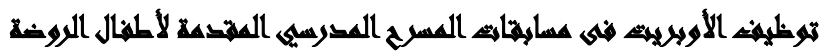

\section{"عراسمة تطليلية"}

يتضح من خلال تحليل بيانات الجدول رقم (11) الآتى:

- أن (فئة الأغانى الفردية) جاءت فى مقدمة الأغانى التى تتاولها الأوبربت بنسـبة ( • 7\%) مـن إجمـالى نوعيـات الأغـانى التى تتاولهـا ، تليها (فئة الأغـانى الجماعيـة) فى الترتيب الثنانى بنسبة ( • ع\%) ،فى حين اختفت بشكل ملحوظ (فئة الأغانى الفردية والجماعيـة) من كل الأوبريتات عينة الدراسـة. وترى الباحثة أن فئة الأغانى الجماعية هي أنسب الأغانى وهى عكس ماتوصلت إليه لغة الأرقام ذلك لأن الغناء الجماعى أو الكورال يسهم فى تعليم الأطفـال التكيف الاجتمـاعى ، ويزبـد مـن شعورهم بالمسئولية، ويصبح هناك لديهم تحمس وتركيز كامل فى العمل . - وتركزت (فئة الأغانى الفرديـة) فى الترتيب الأول بنسبة (00. هـ\%) في أوبريت الحروف تنتلم، ويليه فى الترتيب الثانى أوبريت الأراجوز بنسبة

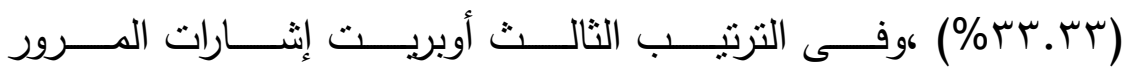

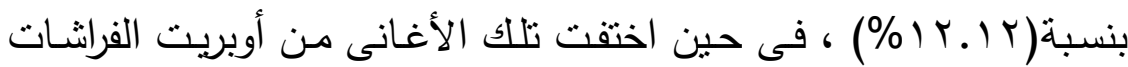
والمكتبة.

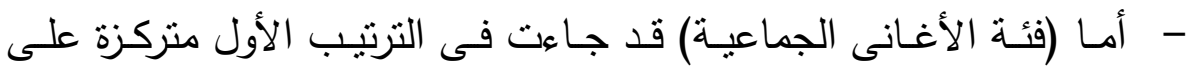

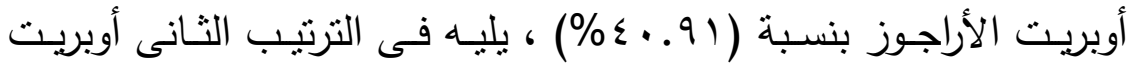

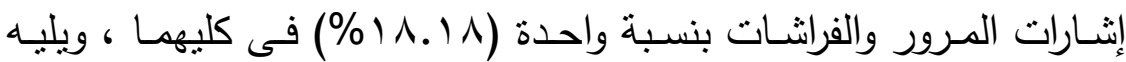
أوبريت المكتبة بنسبة (ع 7. ب (\%) ، وفى الترتيب الأخير أوبريت الحروف

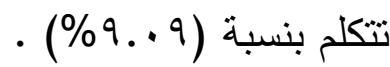
- اختفاء بشكل ملحوظ (لفئة الأغانى الفردية والجماعية) (المشتركة) من كل الأوبريتات عينة الدراسة. 


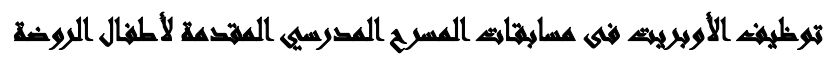

"عراسم تشليليه"

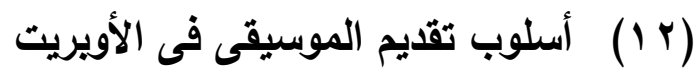

$$
\begin{aligned}
& \text { جدول (Y) }
\end{aligned}
$$

\begin{tabular}{|c|c|c|c|c|c|c|c|c|}
\hline \multicolumn{8}{|c|}{ أسلوب تقديم الموسيقى فى الأويريت } & \multirow{3}{*}{ r } \\
\hline \multicolumn{2}{|c|}{ مج ك } & \multicolumn{2}{|c|}{ تجمع بينى } & \multicolumn{2}{|c|}{ مقبسيةى مقبسة } & \multicolumn{2}{|c|}{ موسيقى مؤلفة } & \\
\hline$\%$ & ك5 & $\%$ & 5 & $\%$ & ك5 & $\%$ & ك & \\
\hline $\begin{array}{c}17.7 \mathrm{~V} \\
\%\end{array}$ & $\Lambda$ & - & - & - & - & $\% \backslash v . r q$ & $\wedge$ & المرور أويريت اشـارات \\
\hline $\begin{array}{c}\mu .0 \Lambda \\
\%\end{array}$ & 19 & - & - & - & - & $\% \leq 1 . \mu$ & 19 & 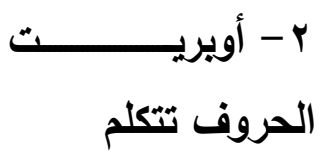 \\
\hline$\%$ Yro & Ir & - & - & - & - & $\%$ \%...9 & Ir & الأراجوز \\
\hline$\% \wedge . r \mu$ & $\varepsilon$ & - & - & - & - & $\% \wedge . \vee$. & $\varepsilon$ & ع الفراشات - أويريــــــــــ \\
\hline $\begin{array}{c}1 . . \varepsilon r \\
\%\end{array}$ & $\bullet$ & - & - & $\% 1 \ldots$ & r & $\% 7.0 \mathrm{r}$ & $r$ & ه - أويريث المكتبة \\
\hline$\% 1 \ldots$ & $\varepsilon \wedge$ & - & - & $\% \varepsilon .1 V$ & r & $\% 90 . \wedge r$ & $\varepsilon 7$ & مج ك \\
\hline
\end{tabular}




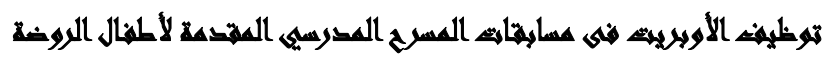

"عراسم تشليليه"

يتضح من خلال تحليل بيانات الجدول رقم (r I) الآتى:

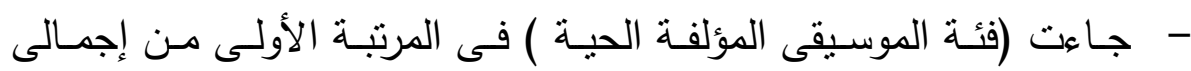

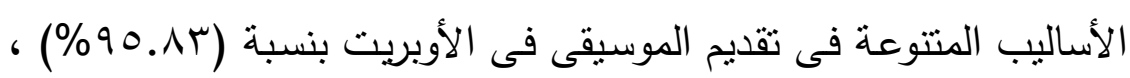

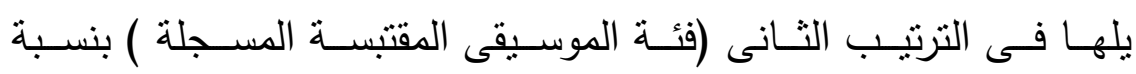

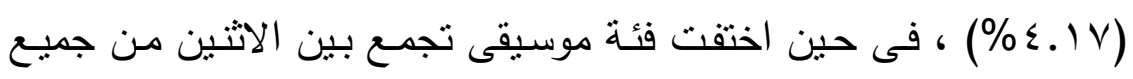
الأوبريتات عينة البحث. وتعكس هذه النتيجة حقيقة هامة هى أن الموسيقى

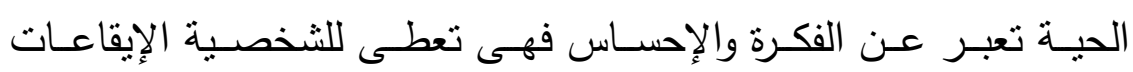
والألحان.

- وجاءت (فئة الموسيقى المؤلفة الحية) متركزة فى الترتيب الأول فى أوبريت

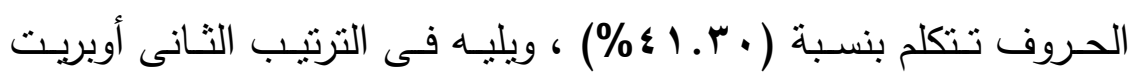
الأراجوز بنسبة (9 . . ؟ \%)، وفى الترتيب الثالث أوبريت إثـارات المرور

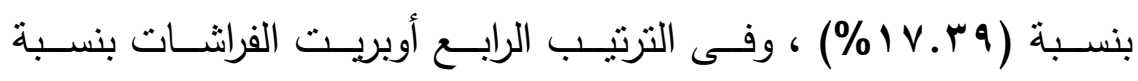

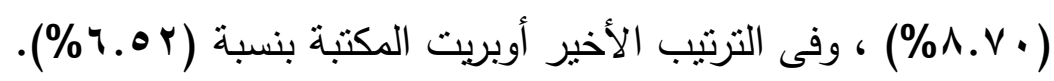

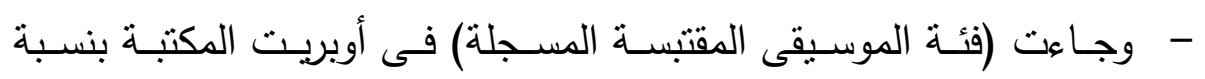

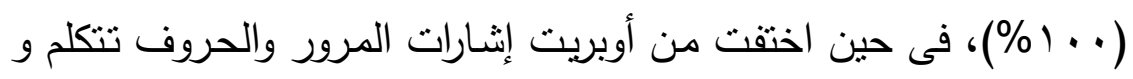
الأراجوز و الفراشات.

- اختفت (فئة موسيقى تجمع بين الإثتين) (أى بين المؤلفة الحية والمقتبسة المسجلة) من جميع أوبريتات البحث . 


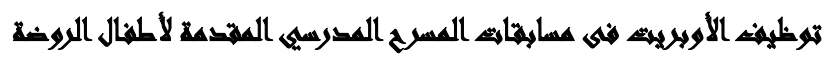

"عراسم تشليليه"

$$
\begin{aligned}
& \text { (T ا I أسلوب تقديم الاستعراضات فى الأويريت } \\
& \text { جدول (IT) }
\end{aligned}
$$

\begin{tabular}{|c|c|c|c|c|c|c|c|c|}
\hline \multicolumn{8}{|c|}{ أسلوب تقديم الاستعراضات فى الأويريت } & \multirow{3}{*}{ r } \\
\hline \multicolumn{2}{|c|}{ مج ك } & \multicolumn{2}{|c|}{ ت تبتعراضا } & \multicolumn{2}{|c|}{ جتعراضات } & \multicolumn{2}{|c|}{ استعراضا فردية } & \\
\hline$\%$ & ك5 & $\%$ & ك & $\%$ & ك5 & $\%$ & ك & \\
\hline $\begin{array}{l}r 4.7 V \\
\%\end{array}$ & $\varepsilon$ & - & - & $\begin{array}{c}r q .7 V \\
\%\end{array}$ & $\varepsilon$ & - & - & المرور أويريسـت اشــارات \\
\hline $\begin{array}{c}\text { M.ru } \\
\%\end{array}$ & $r$ & - & - & 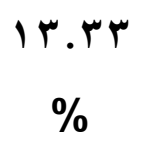 & $r$ & - & - & r - أويريـت الحـروف \\
\hline $\begin{array}{c}\mu . \mu \\
\%\end{array}$ & 0 & - & - & $\begin{array}{c}\text { wr. } \\
\%\end{array}$ & 0 & - & - & r- أويريت الأراجوز \\
\hline 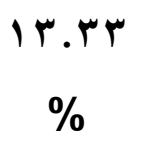 & $r$ & - & - & 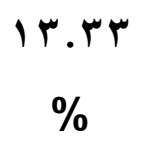 & $r$ & - & - & ع - أويريت الفراشات \\
\hline 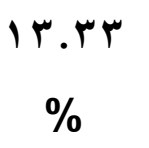 & $r$ & - & - & 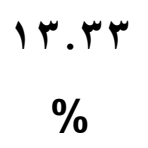 & r & - & - & هـ - أويريت المكتبة \\
\hline$\% 1 \ldots$ & 10 & - & - & $\% 1 \ldots$ & 10 & - & - & مج ك \\
\hline
\end{tabular}




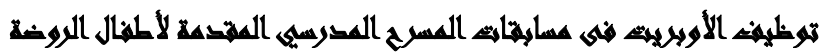

\section{"كراسها تطليلية"}

يتضح من خلال تحليل بيانات الجدول رقم (ب I) الآتى:

- جاءت (فئة استعراضات جماعية) فى المرتبة الأولى من إجمالى الأساليب المتتوعة فى تقديم الاستعراضات فى الأوبريت بنسبة ( . . (\%) من إجمالى

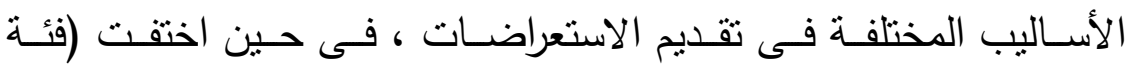
استعراضـات فرديـة) و (فئة استعراضـات تجمـع بـين الاثتين) (أى الفرديـة والجماعية) فى كل أوبريتات البحث . - جاءت ( فئة الاستعراضات الجماعية) مركزة فى الترتيب الأول فى أوبريت الأراجـوز بنسبة (سب.rr\%) ، يليـه فى الترتيب الثانى أوبريـت إثـارات

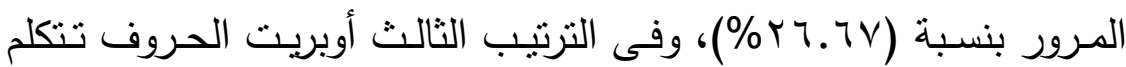

$$
\text { والقراشات والمكتبة بنسبة واحدة هى (rس.r ا (\%). }
$$

- أمـا (فئـات الاستعراضـات الفرديـة) و (فئهة الاستعراضـات التى تجمـع بين الاثثين) (الفردية والجماعية) قد اختفت من جميع أوبريتات البحث . فكان الاستعراض الجماعى يعبرعن مضدون ومعنى معين يريد المخرج نقله

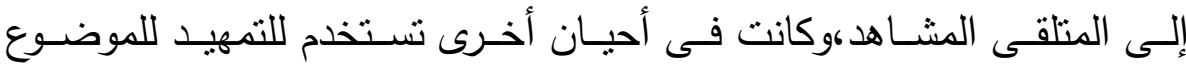
أوالتعليق عليه وذلك بالأداء الحركى والغناء والرقص. 


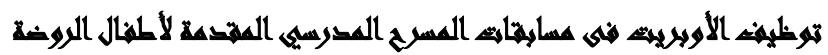

"عراسم تشليليه"

( ع 1) النهاية التى اختتم بها الأويريت

جدول (1)

\begin{tabular}{|c|c|c|c|c|c|c|}
\hline \multicolumn{6}{|c|}{ النهاية التى اختتم بها الأويريت } & \multirow{3}{*}{ r } \\
\hline \multicolumn{2}{|c|}{ مج ك } & \multicolumn{2}{|c|}{ نهاية غير } & \multicolumn{2}{|c|}{ نهاية منطةبة } & \\
\hline$\%$ & ك5 & $\%$ & ك & $\%$ & ك5 & \\
\hline$\% r$. & 1 & - & - & $\% r$. & 1 & 1- أويريث اشارات \\
\hline$\% r$. & 1 & - & - & $\% r$. & 1 & ץ - أويريت الحروف تتكلم \\
\hline$\% r$. & 1 & - & - & $\%$ r. & 1 & r- أويريت الأراجوز \\
\hline$\% r$. & 1 & - & - & $\% r$. & 1 & ع - أويريت الفراشات \\
\hline$\% r$. & 1 & - & - & $\% r$. & 1 & ه - أويريت المكتبة \\
\hline$\% 1 \ldots$ & - & - & - & $\% 1 \ldots$ & 0 & مج ك \\
\hline
\end{tabular}

يتضح من خلال تحليل بيانات الجدول رقم (ع 1) الآتى:

- جاءت (فئة نهايـة منطقيـة) هـى أنسب النهايـات التى اختتم بها الأوبريت حيث بلغت نسبتهم ( . . (\%) من إجمالى أنواع النهايات، بينما اختقت فئة (نهاية غير منطقية) فى جميع الأوبريتات.

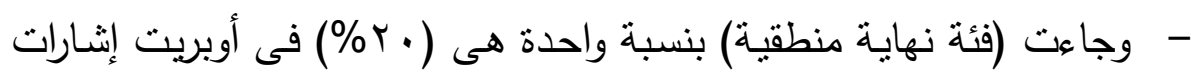
المرور ، والحروف تتكلم، والأراجوز ، والفراشات ،والمكتبة، بينما اختقت (فئة نهاية غير منطقية) فى جميع الأوبريتات. 


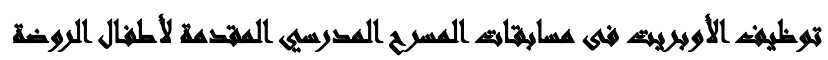

"عراسلا تطليلية"

استناداً إلى الاراسـة التحليلية التى قامت بها الباحثة، فضـلاً عن ملاحظة

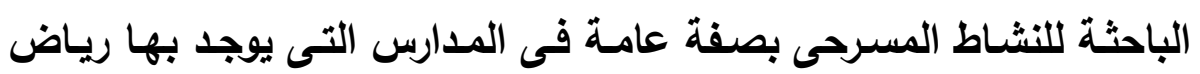

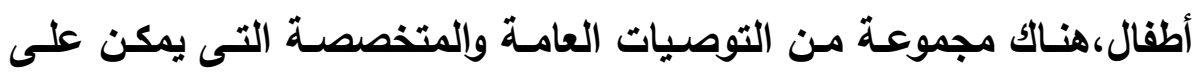

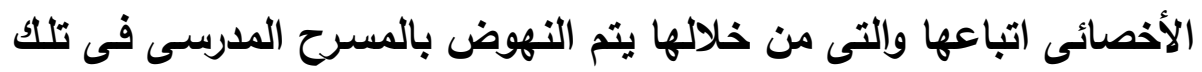
المدارس والتى تتلائم وتتوافق مع هذه هن الفئة ومنها: [أ] توصبيات عامـة: ( ) ضرورة استخدام الأنشطة المسرحية فى رياض الأطفال التي تساعد على تتمية السمات الثخصية لطفل رياض الأطفال.

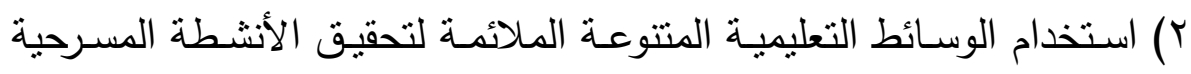

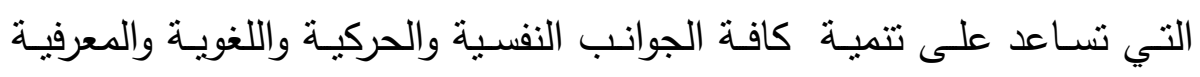
والاجتماعية والصحية للطفل. r) توظيف الغنـاء والموسيقى للمسـاهمة في تحقيـق أهداف تربويـة تعليميـة للطفل.

\section{[ب] توصيات متخصصة :}

() استخدام كلمات أغاني وألحان ملائمة للخصائص النفسية للطفل في مرحلة

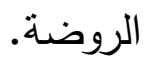
r) ضـرورة توظيف الغناء والإيقاعـات الموسيقية لتتميـة الخصـائص الحركيـة للطفل في مرحلة الروضة لتحقيق الإبداع الموسيقي، الغنائي، الإيقاعي له. له. 


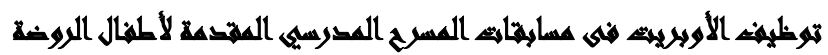

"عراسم تشليليه"

\section{قائمة المراجع}

ا ـ مسعد عويس : دراسة حول مسرح الطفل فى التربية المتكاملة للتشع فح

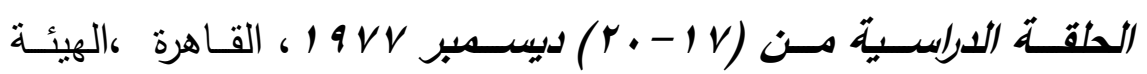

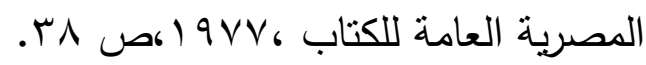

r. محمد عبد المنعم أحمد : المخرج فى المسرح الغنائى المصرى فى الفترة

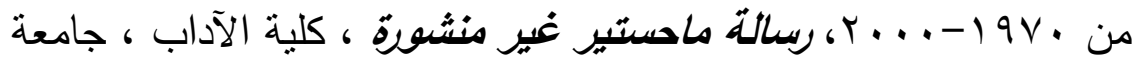

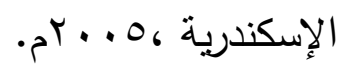

3. Stephen F.Zdzinski and others : Attitudes and practices of Japanese and American music teachers towards integrating music with other subjects, International Journal of Music Education, University of Miami, USA April 2007 vol. 25 no. 1 55-70

4. Murray Frame : The Early Reception of Operetta in Russia, 1860 s -1870s, Journal Citation Reports, University of Dundee, UK, 2013.

•. علا حسن كامل سبد : فعالية برنـامج نشاط تمثيلى مسرحى فى تنميـة مفهوم المواطنـة لأطفال الروضـة ، رسـالة دكتـوراه غير منشسورة، كليـة

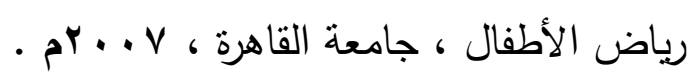
7 . رشا سيد حسين الجندى: فاعلية برنامج لتتمية بعض المهارات الحياتية لدى

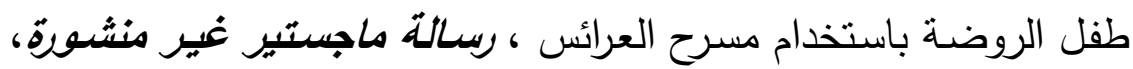

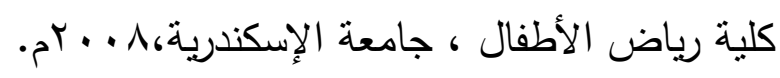




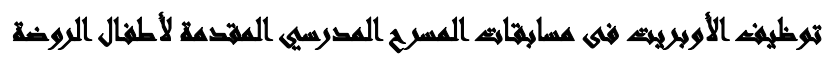

"عراسما تشليلهي"

V. فايزة أحمد عبد الرازق محمد: فعاليـة استخدام مسرح العرائس فى تتميـة

بعض الجوانب الاجتماعية والأخلاقية للتربية البيئية لدى طفل الروضـة ،

رسالةة ماجستير غير منشورة، كلية التربية ، جامعة المنصورة ، 1 ـ . بام.

8. Garvis, Susanne : Exploring current arts practice in kindergartens and preparatory classrooms , Australasian Journal of Early Childhood. Dec2012, Vol. 37 Issue 4, p86-93.

9 • ربهام ربيع مصطفى العيوطى: تتمية بعض المفاهيم الاقتصـادية باستخدام الأنشطة المسرحية وعلاقتها بمظاهر السلوك التواققى لطفل الروضـة (ع 7) سنوات ، رسيالة دكتوراه غير منشورة، كلية رباض الأطفال ، جامعة

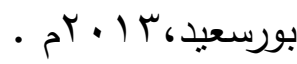

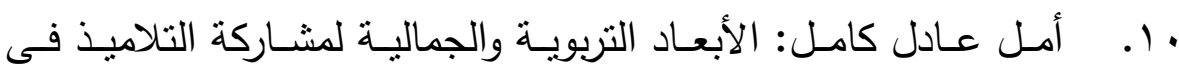
تصميم خلفيات المسرح المدرسى ، رسالة ماجستير غير منشسوة ، كلية التربية الفنية ، جامعة حلوان، 9 ، . بم. ا1 ا. نورة عبد العزيز على محمد: دمس المسرح المدرسى المتحركة كمثير لتدريس الأثـال الفنيـة لتلاميذ المرحلة الإعداديـة كرسالة ماجستير غير

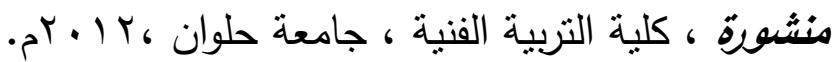
r ا. نجلاء محمد محمود محمود عبد الله: دور المسرح المدرسى فى اكساب الأطفال المعلومات البيأية ، رسالةة ماجستير غير منشورة ، كلية التربية

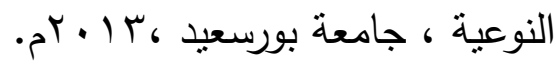




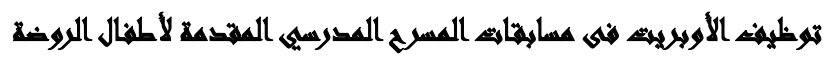

"عراسما تشليلية"

rا . مجلــة المســرح: العـدد الثـامن والأربعـون، السـنة الرابعـة، ديسـمبر (P) $197 \mathrm{~V}$

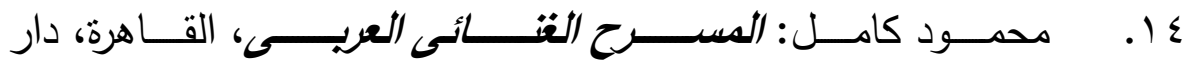

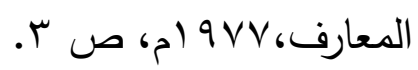

1 . نبيل راغب: النقد الفنى، طا، دار نوبار للطباعـة، القاهرة، 999 (م، . $1 \leq 0$ ص

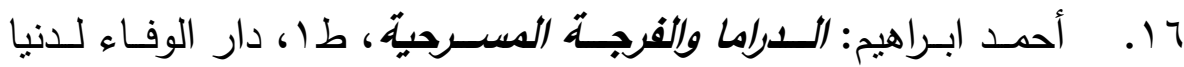

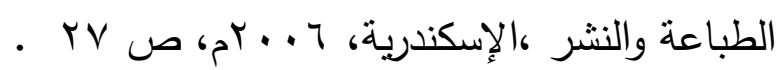

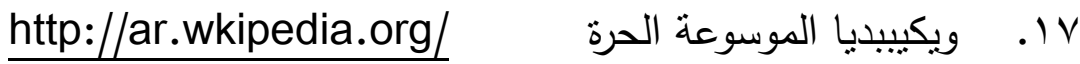
11 ا. نافذة المسرح لكل المسرحيين المصريين http://www.masrahy.net.tc/

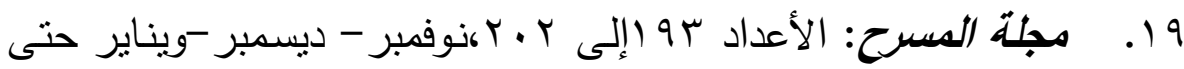

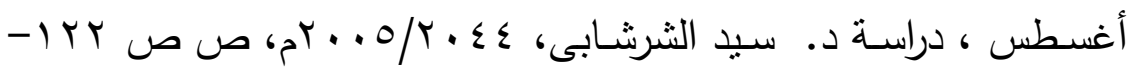
Trו.

• ץ. آمال أحمد مختار صادق: لغة الموسبقى، طا (القاهرة، مركز التتمية

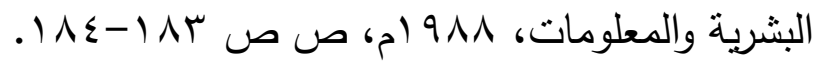

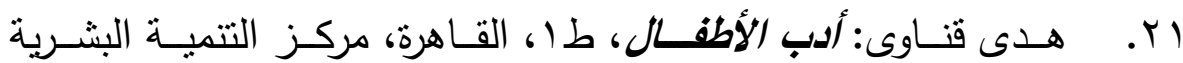

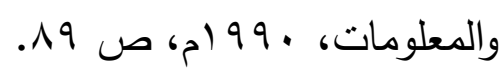

r r . س سهير كامل أحمد ، شحاتة سليمان محمد: تتشئة الطفل وحاجاتهه بين

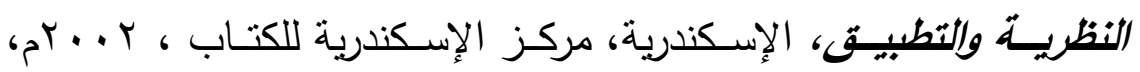

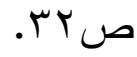




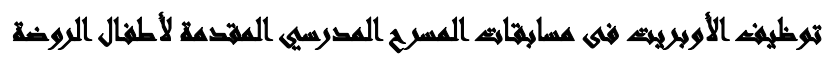

"عراسم تشليليه"

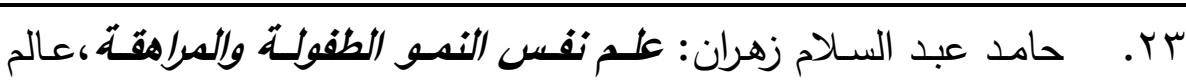

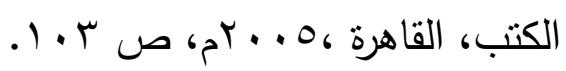

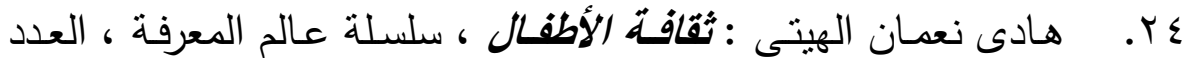

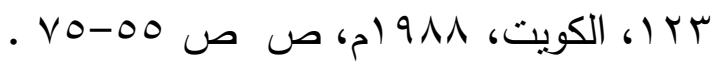

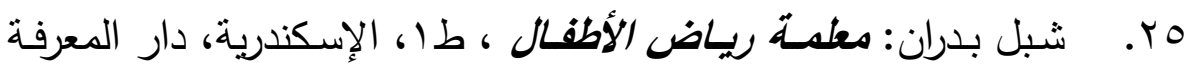

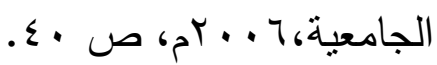

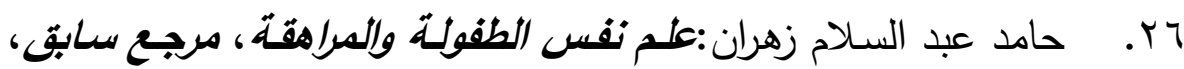

$$
\text { ص ז }
$$

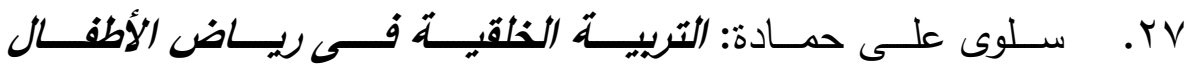

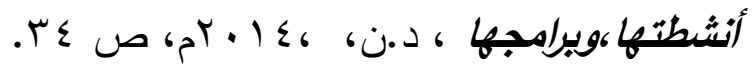

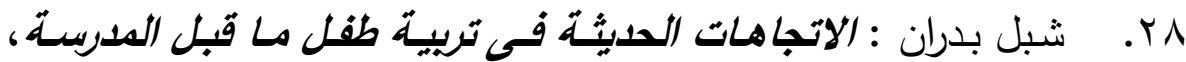

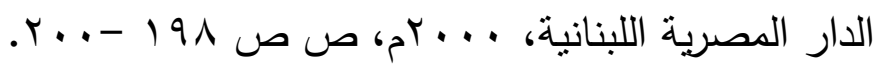

9 . منتدى رياض الأطفال ، سـعاء المعرفـة ، التربيـة و التعلـيم ،عالم http://samamar.ahlamontada.com/ الطفل ، تربية الطفل. •r. حامد عبد السلام زهران:علم نفس الطفولة والمراهقة، مرجع سابق، ص لـ .410

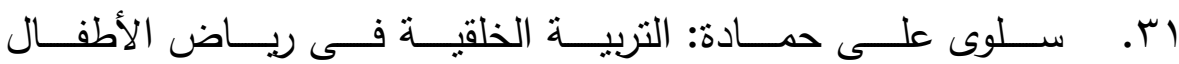
أنشطتها،وبرامجها ، مرجع سابق ، ص rr. سهير كامل أحمد، سيكولوجية نمد الطفل دراسـات نظريسة وتطبيقات

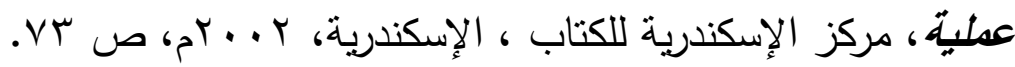




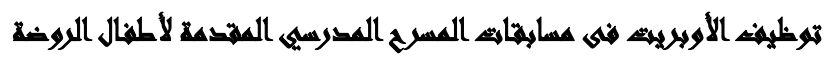

"عراسما تشليلية"

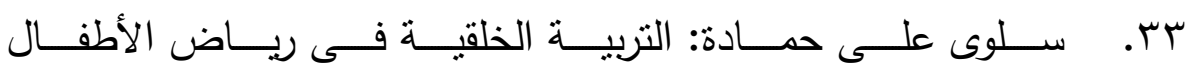
أنشطتها،وبرامجها ، مرجع سابق ، ص مبـ

ع س. حامد عبد السلام زهران:علم نفس الطفولة والمراهقة، مرجع سابق، ص . TYA

هـ. محمد عبد الغفار وآخرون: علم النفس النمو، القاهرة، مكتبة النهضة

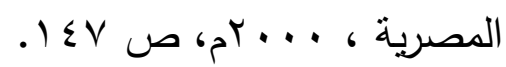

بس. سهير كامل أحمد ، شحاتة سليمان محمد: تنشئة الطفل وحاجاته بين

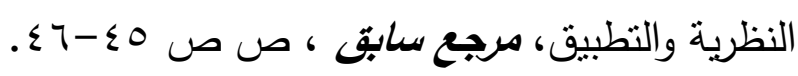
rV

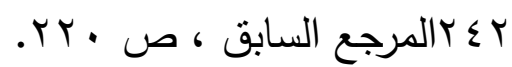

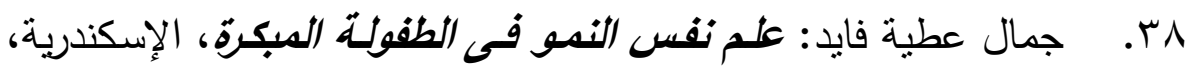

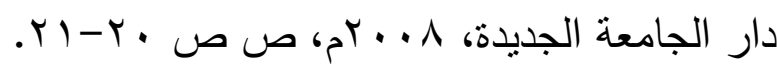
q". محمود حسن اسماعيل: منساهج البعث فـى إعلام الطفل ،القاهرة،دار

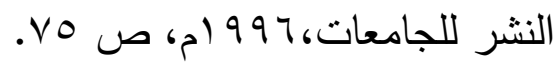

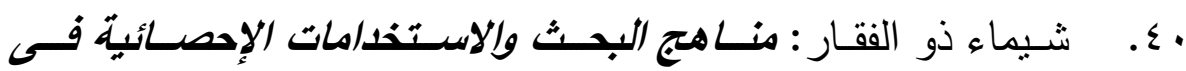

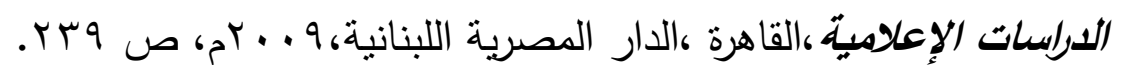

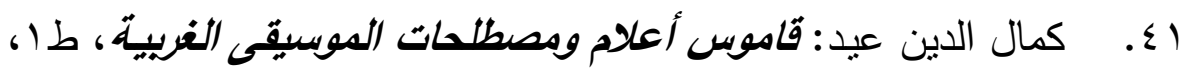

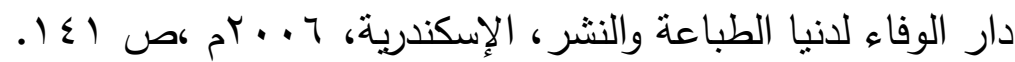

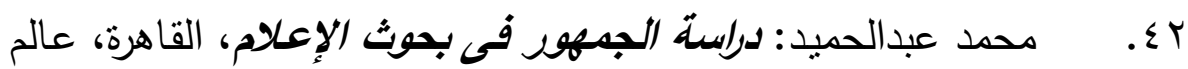

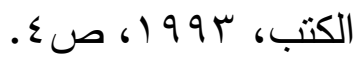




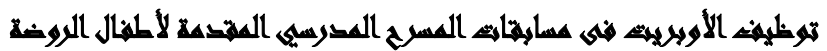

\section{"عراسمة تحليلية"}

بـ. * أ.د//إسماعيل عبد الفتاح عبد الكافى :أستاذ أدب الأطفال،الهيئة العامة للاستعلامات، القاهرة.

*أ.د / على عبد الودود محمد: أستاذ التربية الموسيقية، كلية التربية

النوعية ،جامعة بنها.

* أ.د / فاطمة يوسف : أستاذ النقد الأدبى المسرحى المتقرغ ،كلية التربية النوعية،جامعة بنها.

*أ.د/ مها صلاح الدين: أستاذ رياض الأطفال ، كلية التربية النوعية كامعة بنها.

* أ / ممدوح حسين سالمان : موجه عام التربية المسرحية،محافظة القليوبية الم

§ . محد عبد الحمبد : تحليل المحتوى فحى بحوث الإعلام، السعودية ،دار

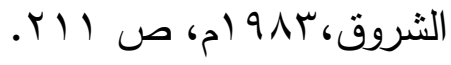

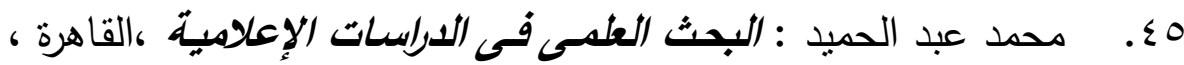

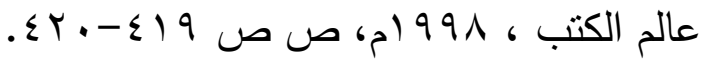

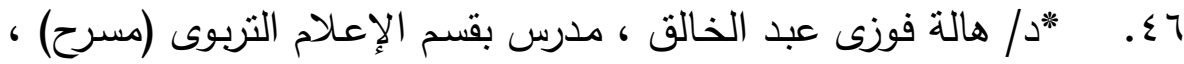
كلية التربية النوعية ، جامعة طنطا. *د/ مـروة الحسـينى محمـد ، مـدرس بقسـم ريساض الأطفـال ، كليـة التربية النوعية ، جامعة بنها. عV التجربيية ، إدارة شبين القناطر التعليمية، محافظة القليوبية، ع ا. r. 


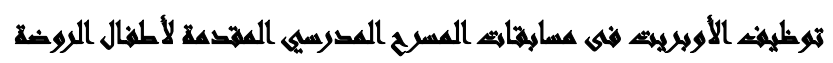

\section{"عراسمة تطليلية"}

^乏. ابراهيم حمادة: هوامش فحى الدراما، القاهرة، الهيئة المصرية العامة

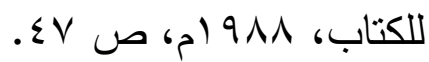

9 . أوبيريث الحروف تتكلم :مسرحة مناهج، مدرسة سليم زهنى الخاصـة، إدارة شبين القناطر التعليمية، محافظة القليوبية ـ ا ـ بم.

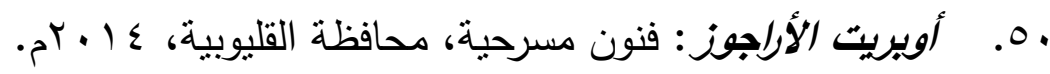
01. أوبيربت الفراثـات : أعياد طفولة، مدرسـة سليم زهنى الخاصـة، إدارة بنها التعليمية، محافظة القليوبية، إ ا • rم. ror ناديـة عبد العزبز : أغانى الأطفال مسئولية من....؟، الكويت ، مجلـة

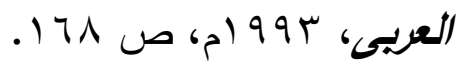

ror. أوبيريت المكتبة : أعياد طفولة، مدرسة سليم زهنى الخاصة، إدارة بنها

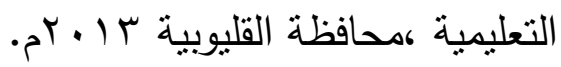

ـه. على الراعى: مسرح الشعب، القاهرة، الهيئة المصرية العامة للكتاب، ( n 